Winter 1992

\title{
Paleomagnetism and Tectonics of the Crescent Formation Northern Olympic Mountains, Washington
}

Andrew C. (Andrew Clyde) Warnock

Western Washington University

Follow this and additional works at: https://cedar.wwu.edu/wwuet

Part of the Geology Commons

\section{Recommended Citation}

Warnock, Andrew C. (Andrew Clyde), "Paleomagnetism and Tectonics of the Crescent Formation Northern Olympic Mountains, Washington" (1992). WWU Graduate School Collection. 816.

https://cedar.wwu.edu/wwuet/816

This Masters Thesis is brought to you for free and open access by the WWU Graduate and Undergraduate Scholarship at Western CEDAR. It has been accepted for inclusion in WWU Graduate School Collection by an authorized administrator of Western CEDAR. For more information, please contact westerncedar@wwu.edu. 


\section{PALEOMAGNETISM AND TECTONICS OF THE CRESCENT FORMATION}

NORTHERN OLYMPIC MOUNTAINS, WASHINGTON

Andrew C. Warnock

Accepted in Partial Completion of the. Requirements for the Degree

Master of Science

Advisory Committee

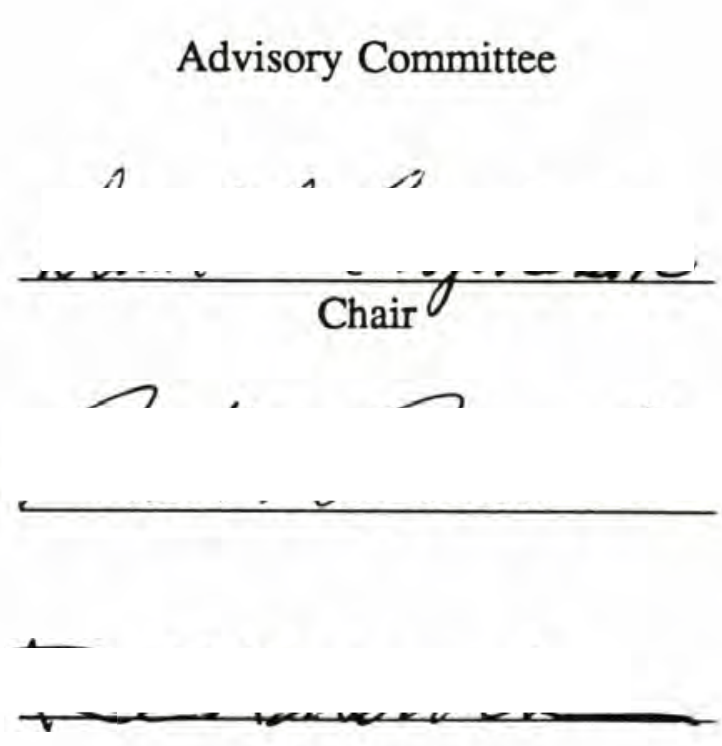

Dean of Graduate Schgol

- 


\section{MASTER'S THESIS}

In presenting this thesis in partial fulfillment of the requirements for a master's degree at Western Washington University, I agree that the Library shall make its copies freely available for inspection. I further agree that extensive copying of this thesis is allowable only for scholarly purposes. It is understood, however, that any copying or publication of this thesis for commercial purposes, or for financial gain, shall not be allowed without my written permission.

Signature

Date $2 / 19 / 92$ 


\title{
PALEOMAGNETISM AND TECTONICS OF THE CRESCENT FORMATION NORTHERN OLYMPIC MOUNTAINS, WASHINGTON
}

\begin{abstract}
A Thesis Presented to the Faculty of Western Washington University
\end{abstract}

In Partial Fulfillment of the Requirements for the Degree Master of Science

by

Andrew C. Warnock

February 1992 


\section{MASTER'S THESIS}

In presenting this thesis in partial fulfillment of the requirements for a master's degree at Western Washington University, I grant to Western Washington University the non-exclusive royalty-free right to archive, reproduce, distribute, and display the thesis in any and all forms, including electronic format, via any digital library mechanisms maintained by WWU.

I represent and warrant this is my original work and does not infringe or violate any rights of others. I warrant that I have obtained written permissions from the owner of any third party copyrighted material included in these files.

I acknowledge that I retain ownership rights to the copyright of this work, including but not limited to the right to use all or part of this work in future works, such as articles or books.

Library users are granted permission for individual, research and non-commercial reproduction of this work for educational purposes only. Any further digital posting of this document requires specific permission from the author.

Any copying or publication of this thesis for commercial purposes, or for financial gain, is not allowed without my written permission.

Name: Andrew C. Warnock

Signature:

Date: June 30,2018 


\section{ABSTRACT}

Use of a small-diameter core drill has allowed the paleomagnetic sampling of the rims of fractured pillow basalts of the lower Crescent Formation in the northern Olympic Mountains. The pillows selected have spherical or oblate morphologies which typically develop on horizontal or mildly-dipping surfaces. Pillow keel structures and sedimentary interbeds were used to obtain bedding attitudes and top directions for use in structural corrections. All specimens were subjected to progressive thermal demagnetization. After removal of a low blocking-temperature recent overprint, stable endpoints were reached by $580^{\circ} \mathrm{C}$ in 11 of the 33 sites sampled (large within-site scatter was commonly observed in the remaining sites). Among the accepted sites, within-site scatter was small and correction for bedding tilt significantly reduced the scatter between sites. The mean paleomagnetic pole for this investigation is $86.4^{\circ}$ north latitude, $170.0^{\circ}$ east longitude, $\mathrm{A}_{95}=16.5^{\circ}$ which agrees with the expected early to middle Eocene pole for North America. When combined with previous work from subaerial basalt exposures of the upper Crescent Formation in and near the eastern Olympic Mountains, these results $\left(80.7^{\circ}\right.$ north latitude, $192.0^{\circ}$ east longitude, $\mathrm{A}_{95}=8.0^{\circ}, \mathrm{N}=46$ ) show no significant rotation $\left(0.8^{\circ} \pm 14.4^{\circ}\right)$ or poleward displacement $(-3.6 \pm 8.5)$. Analysis of the magnetic mineralogy suggests that the remanence is early, if not primary. The pole, therefore, should be valid for tectonic interpretation of the region. A circular distribution of virtual geomagnetic poles after correction for bedding tilt supports the hypothesis that the northern Crescent Formation experienced deformation due to the rise, in a dome-like fashion, of the sediments of the Olympic Core terrane. Erosion of a partial dome open to the west could have produced the curvature seen in the 
outcrop pattern of the Crescent Formation. The lack of significant rotation of the northernmost Coast Ranges is in contrast with the net clockwise rotation seen to the south. A possible explanation for this difference may be that southern Vancouver Island acted as a backstop thereby restricting rotational deformation. In addition, the Olympic Mountains may have been north of the rotational influence of differential Basin and Range extension. 


\section{ACKNOWLEDGEMENTS}

This project has benefited greatly from the generosity and enthusiasm of Dave Engebretson. Scott Babcock added encouragement and kept reminding me about the big picture. Myrl Beck Jr. was a great teacher and provided sound advice. Sherman Grommé measured the Curie temperatures and provided insights into the rock magnetism. Jim Talbot helped with the structural analysis, and George Mustoe taught me the ins and outs of sample preparation.

Late night conversations with Harold Cashman, José Cembrano, Bernie Dougan, Kathleen Duggan, Steve Fluke, David Haasl, Joel Harper, Dan McShane, Connie Rojas, and Ruth Schmidt were always enjoyable. Thank you. Krista Swanson was wonderful. Martha, Robert, and Kevin Warnock provided moral support. And above all, I would like to thank Russ Burmester, a mentor and friend, and Kevin Kelley for being a part of this project from the beginning. 


\section{TABLE OF CONTENTS}

ABSTRACT iv

ACKNOWLEDGEMENTS Vi

LIST OF FIGURES $\quad$ viii

LIST OF TABLES $\quad$ ix

$\begin{array}{ll}\text { INTRODUCTION } & 1\end{array}$

GEOLOGIC SETTING

$\begin{array}{ll}\text { PALEOMAGNETISM } & 9\end{array}$

Sample Collection and Determination of Paleohorizontal 9

Measurement and Demagnetization of NRM 11

Analysis of NRM Demagnetization $\quad 12$

$\begin{array}{ll}\text { Paleomagnetic Directions } & 16\end{array}$

Comparison with Previous Paleomagnetic Studies $\quad 20$

Timing of Acquisition of Magnetization $\quad 26$

REGIONAL TECTONICS 32

Deformation of the Crescent Formation $\quad 32$

Relation to Regional Paleomagnetic Rotations

$\begin{array}{ll}\text { CONCLUSIONS } & 37\end{array}$

$\begin{array}{ll}\text { REFERENCES } & 39\end{array}$

APPENDIX: Sample Directions $\quad 44$ 


\section{LIST OF FIGURES}

Geologic map of the Oregon and Washington Coast Ranges

Geologic map of the Olympic Peninsula

Continental margin rift-basin model

Alternating field demagnetization of IRM

Orthogonal projection of thermal demagnetization

Plot of sample directions for two sites

Plot of site-mean directions for the lower Crescent Formation

Plot of site-mean VGPs for the combined dataset

Photomicrograph of a typical lower Crescent pillow basalt 27

Thermomagnetic curves for the rim and core of a pillow basalt

Photomicrograph of a typical upper Crescent subaerial basalt

Comparison of three models for the deformation of the Crescent Formation 


\section{LIST OF TABLES}

Site-mean directions for the lower Crescent Formation

Site-mean VGPs for the Crescent Formation

Mean paleomagnetic poles for the Crescent Formation 


\section{INTRODUCTION}

The Coast Ranges of Oregon and Washington are characterized by Paleocene to middle Eocene basalt accumulations that were accreted to or are the result of a rift within the western margin of North America. Paleomagnetic rotations of the Coast Range basalts increase from none at the north [Beck and Engebretson, 1982; Irving and Massey, 1990; this paper] to as much as $80^{\circ}$ of net clockwise rotation to the south [Simpson and Cox, 1977; Wells et al., 1985; Beck, 1989; Wells, 1990] (Figure 1). Wells and Heller [1988] addressed the relative contribution of three proposed rotation mechanisms: rotation during accretion [Simpson and Cox, 1977; Magill et al., 1981; Duncan, 1982], non-rigid dextral shear rotation due to coupling between North America and the obliquely converging Farallon or Kula plates [Beck, 1976, 1980], and rigid rotation due to differential extension of the Basin and Range Province [Simpson and Cox, 1977; Magill et al., 1981; Heller, 1983; Frei et al., 1984; Grommé et al., 1986]. Wells and Heller [1988] concluded that a combination of rotations due to Basin and Range extension and oblique convergence fits the geologic and paleomagnetic data without invoking complicated accretion models. The lack of rotation found in the northern Coast Range must indicate a tectonic history different from the exposures to the south.

In the Olympic Mountains of northwestern Washington, the basalts of the Coast Range belong to the Crescent Formation. Their outcrop pattern shows a distinct curvature (Figure 2). The curvature could be an artifact of a primary distribution of basalts, perhaps reflecting two centers of extrusion [Cady, 1975; Tabor and Cady, 1978b]. Alternatively, the curvature could represent folding of a linear trend of basalts about 


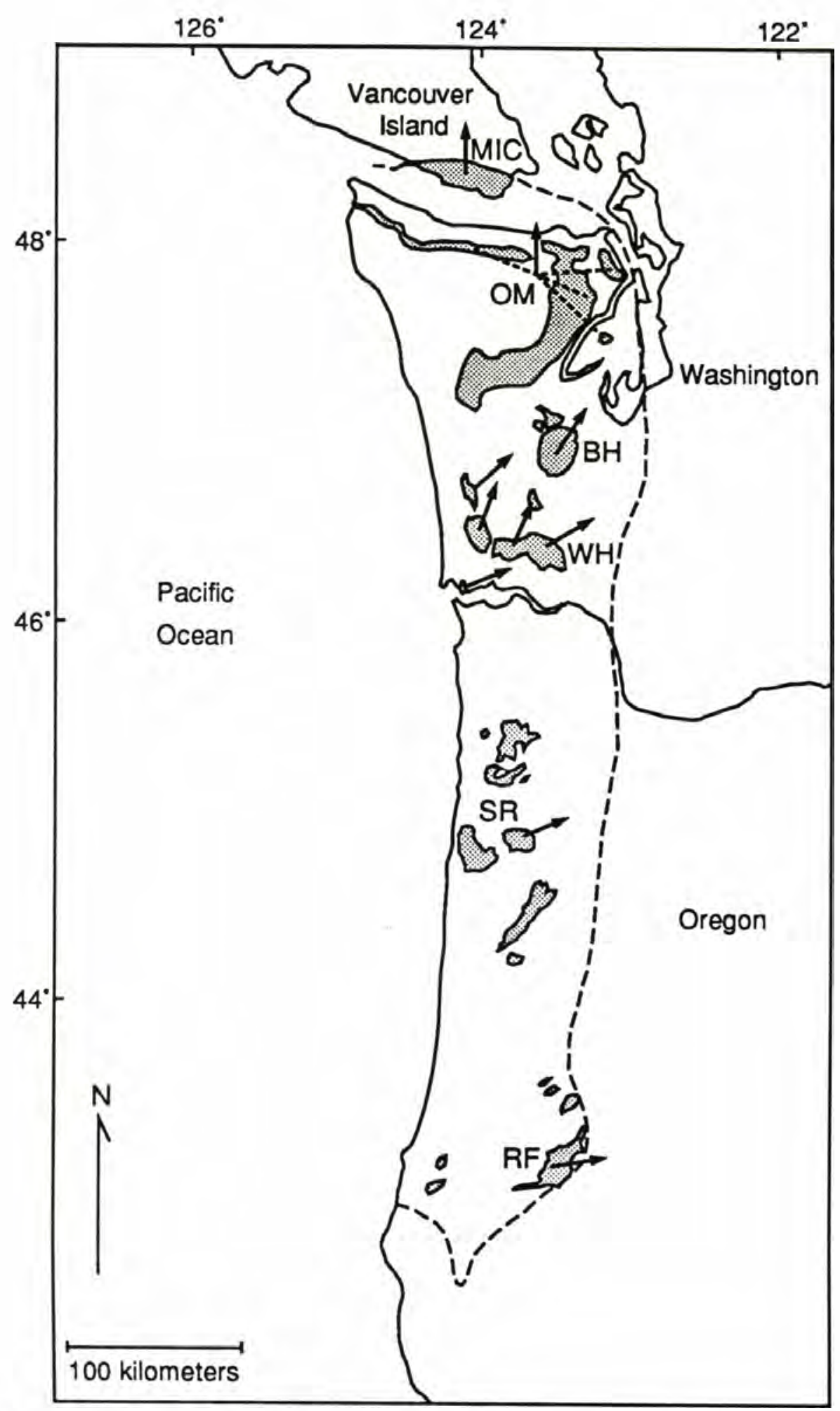

Figure 1: Generalized geologic map of the Oregon and Washington Coast Ranges showing paleomagnetic rotations (arrows pointing due north imply no net rotation) in Paleocene to middle Eocene oceanic basalts. Note north to south increase in amount of rotation. MIC: Metchosin Igneous Complex [Irving and Massey, 1990], OM: Olympic Mountains [this study], BH: Black Hills [Globerman et al., 1982], WH: Willipa Hills [Wells and Coe, 1985], SR: Siletz River [Simpson and Cox, 1977], RF: Roseburg Formation [Wells et al., 1985]. Geology from Snavely [1987]. 


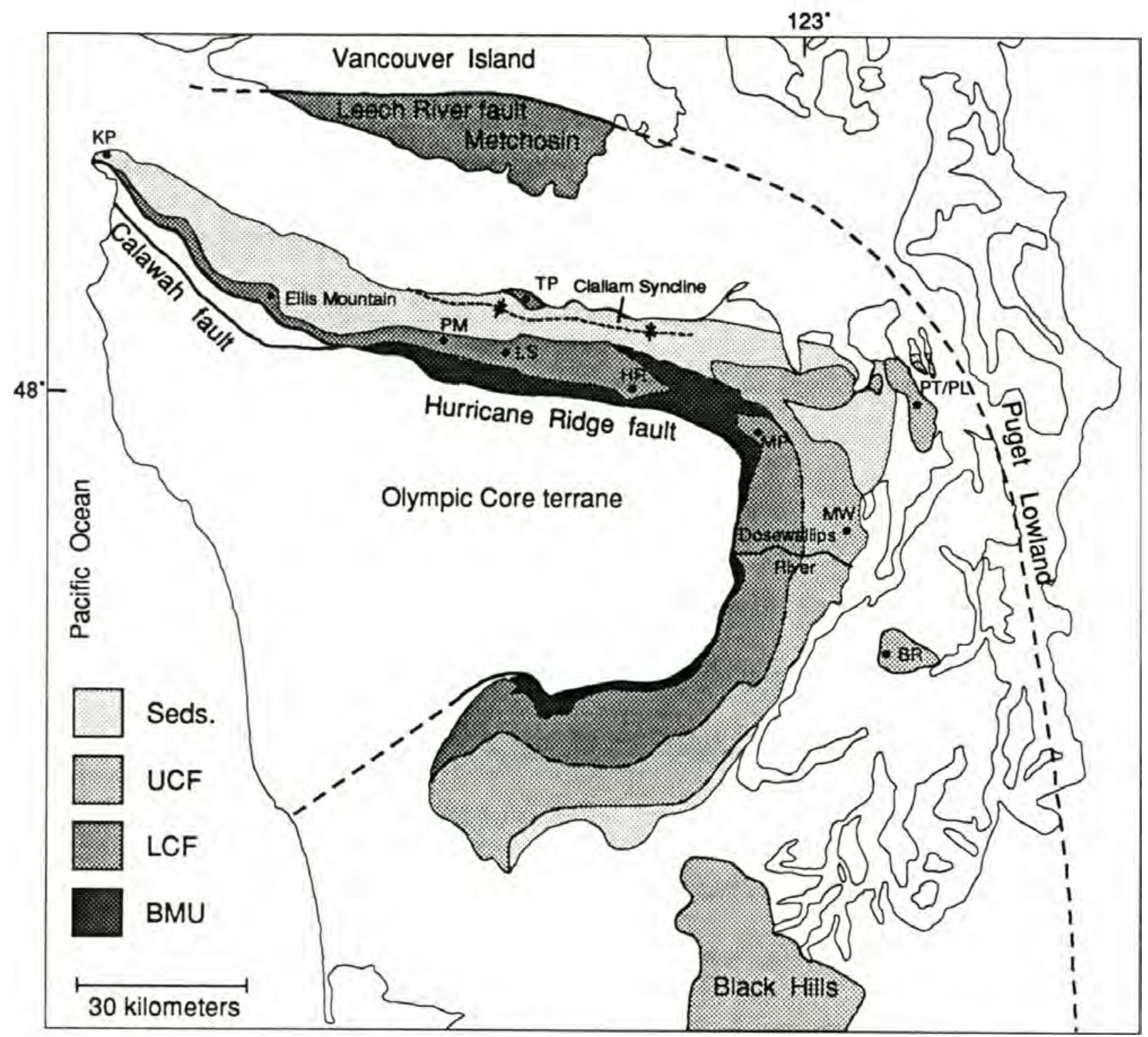

Figure 2: Generalized geologic map of the Olympic Peninsula showing the curvature of the Crescent Formation outcrop pattern and paleomagnetic sampling localities. PM: Pyramid Mountain, LS: Lake Sutherland, HR: Hurricane Ridge, and MP: Maynard Peak [this study], KP: Kydikabbit Point, TP: Tongue Point [Moyer, 1985], MW: Mount Walker [Warnock, 1989], PT/PL: Port Townsend/Port Ludlow [Beck and Engebretson, 1982; Warnock, 1989], BR: Bremerton [Beck and Engebretson, 1982; Purdy, 1987]. Seds: Sedimentary rock formations; UCF: upper Crescent Formation; LCF: lower Crescent Formation; BMU: Blue Mountain unit. Geology from Tabor and Cady [1978a]. 
vertical axes (oroclinal bending of Carey [1958]), erosion of a layered sequence deformed into an eastward-plunging antiform [Weaver, 1937], or erosion of a domelike structure [Cady, 1975]. Understanding the deformation which resulted in the curvature will contribute to our understanding of the emplacement of the subduction complex, partially bounded by the curvature. Paleomagnetic methods should aid in resolving this structural problem. Early unpublished studies, however, found the basalts of the Crescent Formation to be magnetically useless [M.E. Beck Jr., personal communication, 1988].

Recent paleomagnetic studies of the Crescent Formation in and near the Olympic Mountains, and of the correlative Metchosin Igneous Complex on southern Vancouver Island (Figure 2), have reported both clockwise and counterclockwise rotations, as well as concordance. The study of Beck and Engebretson [1982], supplemented by Purdy [1987] and Warnock [1989], lacked the broad geographic coverage required to unravel the regional structural and tectonic history. Moyer [1985] studied predominantly sedimentary rocks overlying the Crescent Formation, most of which failed to retain their primary remanence. Irving and Massey [1990] studied intrusive rocks of the Metchosin Igneous Complex which lacked structural control on a local scale. The goal of this project was to study the paleomagnetism of the Crescent basalts of the northern Olympic Mountains where better stratigraphic control and large areal extent might be sufficient to make sense of the existing ambiguous directions and to learn about the emplacement and deformation of the rocks of the Olympic Mountains. 


\section{GEOLOGIC SETTING}

The Olympic Mountains are comprised of two major fault-bounded terranes: the Olympic Core terrane and the Crescent terrane [Tabor and Cady, 1978b; Silberling et al., 1984] (Figure 2). The Olympic Core terrane, in fault contact with the Crescent terrane on the north, east and southeast (Figure 2), represents a subduction complex of Eocene to Miocene marine turbidites that have been metamorphosed to the prehnitepumpellyite, low-grade greenschist, and the blueschist facies in the eastern portion of the complex with a general increase in metamorphic grade from west to east [Tabor and Cady, 1978a; Brandon and Calderwood, 1990].

The Crescent terrane is separated from the Olympic Core terrane by the Hurricane Ridge and Calawah faults [Tabor and Cady, 1978a; Gower, 1960] (Figure 2). The Leech River fault on Vancouver Island marks the northern boundary [Clowes et al., 1987] and to the east lies a poorly-defined boundary within the Puget Lowland [Roberts, 1990] (Figure 2). The Blue Mountain unit lies at the base of Crescent terrane stratigraphy and consists of continentally-derived sediments [Cady, 1975]. The Blue Mountain unit is overlain by and laterally interfingers with the lower member of the lower to middle Eocene Crescent Formation [Cady, 1975], characterized by submarine pillow basalt with minor clastic sediments and red limestone lenses. In the eastern section, the lower Crescent Formation is overlain by subaerial basalts that are considered to be the "upper member" of the Crescent Formation by Glassley [1974]. The Crescent Formation is overlain by upper Eocene to lower Miocene unmetamorphosed marine clastic sediments (Figure 2). On a regional scale, the basalts of the lower Crescent Formation and the lower portion of the upper Crescent Formation 
appear to have been metamorphosed to the prehnite-pumpellyite facies; locally, lower Crescent basalts have been metamorphosed to the greenschist facies [Glassley, 1974].

Early estimates of the age of the lower Crescent Formation were made by correlation of Foraminifera from intraflow limestone lenses. Foraminifera from the lower Crescent Formation indicate a lower to middle Eocene age [Rau, 1964; Cady et al., 1972]. Recent ${ }^{40} \mathrm{Ar} /{ }^{39} \mathrm{Ar}$ whole-rock age dates from the lower and upper Crescent basalts in the Olympic Mountains [Babcock et al., 1991] range from $45.4 \pm 0.6 \mathrm{Ma}$ to $56.0 \pm 1.0 \mathrm{Ma}$ and confirm the fossil dates.

The Crescent Formation has been interpreted as a seamount chain that was accreted to North America [Snavely et al., 1968; Duncan, 1982]. There are several problems with this interpretation. First, the interfingering of continentally derived sediments of the Blue Mountain unit at the base of the Crescent terrane and the conformable marine clastic sedimentary units overlying the Crescent Formation suggest a near-shore setting [Cady, 1975]. Second, the three-meter diameter clasts of quartz diorite that have been found within the eastern section of the Crescent Formation also indicate a near-shore setting [Cady, 1975]. Third, recent structural and stratigraphic studies of the Metchosin Igneous Complex [Brandon and Massey, 1985; Massey, 1986] and the basalts of the eastern section of the Crescent Formation [Clark, 1989; Babcock et al., 1992] suggest that a continental margin rift setting [Wells et al., 1984] may be a more appropriate interpretation. Fourth, if the Crescent basalts formed on either the Farallon or Kula plate at their time of extrusion, modeled plate motions would predict paleomagnetic inclinations significantly shallower than observed [Wells et al., 1984; Einarsen and Engebretson, 1987]. 
An alternative model for the formation of the Crescent basalts is based on plate reconstructions [Babcock et al., 1992]. The Kula and Farallon plates are the only two plates known to have interacted with northwestern North America at the time of extrusion. Plate tectonic models for the region during the Eocene show that the KulaFarallon ridge was impinging upon North America, creating a ridge-trench-trench triple junction [Engebretson et al., 1985; Stock and Molnar, 1988]. The geometry of this triple junction suggests that a "no-slab window" may have been responsible for back-arc rifting in a near-shore basin [Babcock et al., 1992] (Figure 3). In addition, the Yellowstone hotspot may have contributed to observed age progressions and geochemical signatures [Duncan, 1982; Wells et al., 1984; Babcock et al., 1992]. 


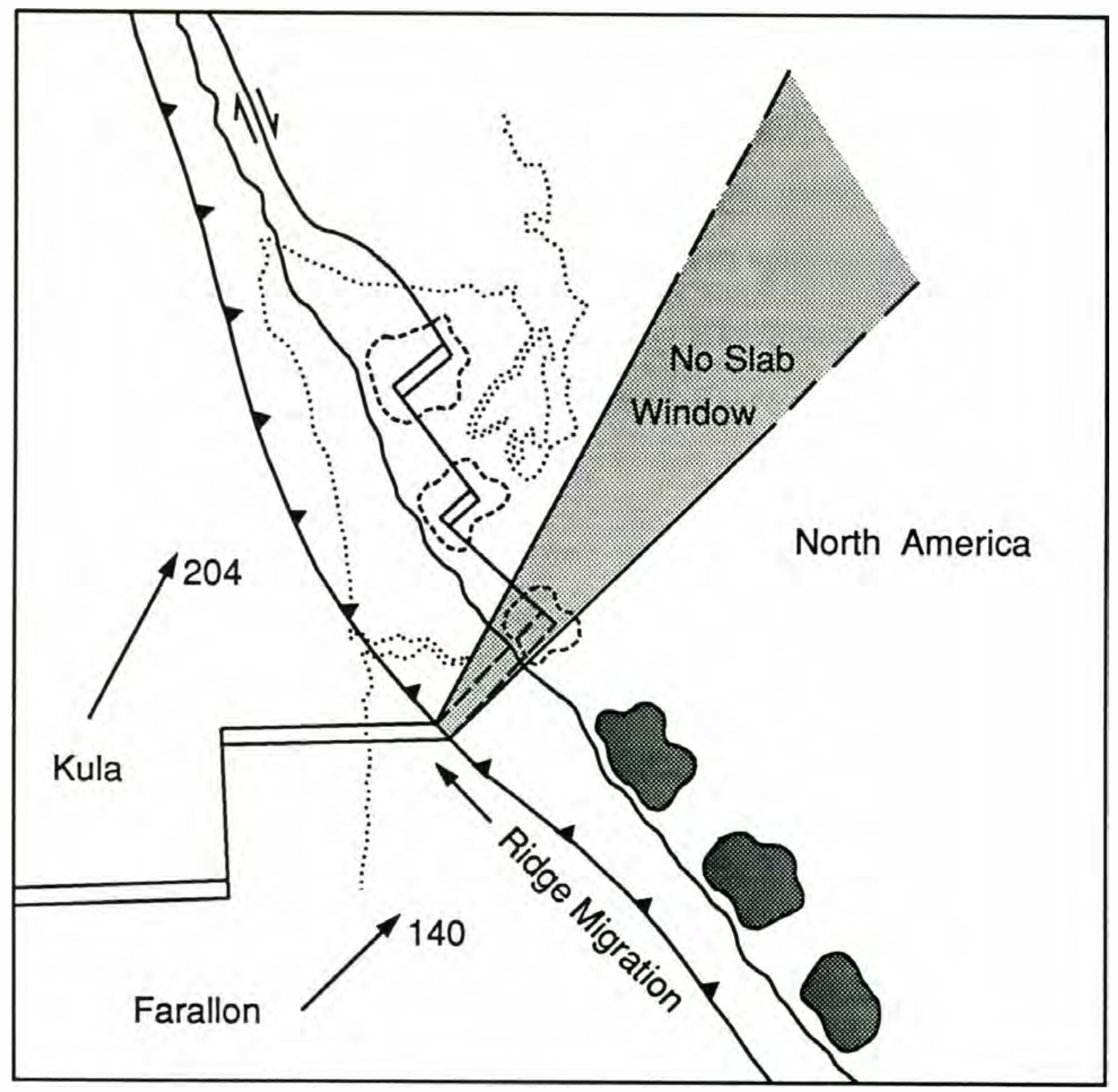

Figure 3: Continental margin rift-basin model for the lower Eocene showing the geometry of the no-slab window [Babcock et al., 1992]. Darker shaded areas are hypothetical basalt exposures. Azimuth of trench from Wells and Heller [1988]; plate motions from Engebretson and others [1985] are in $\mathrm{km} / \mathrm{m}$.y. relative to North America. 


\section{PALEOMAGNETISM}

Sample Collection and Determination of Paleohorizontal

Five to fourteen (mostly six to eight) cores were collected from each of 33 sites of pillow basalt of the lower Crescent Formation in the northern Olympic Mountains. Only roadcuts were sampled in order to obtain the freshest possible rock for magnetic analysis, and to cover the largest area with the time and resources available. Suitable roadcuts from the Dosewallips River (southeast) to Ellis Mountain (west) were sampled (Figure 2). Active logging and highly-weathered exposure discouraged sampling west of Ellis Mountain.

Six sites near Lake Sutherland (LS) were sampled with a standard $2.54 \mathrm{~cm}$ diameter core drill. Remaining sites were drilled with a specially-designed, battery-operated drill in order to sample fractured pillow rims precisely with a smaller $(0.9 \mathrm{~cm}$ diameter) bit. Rims were targeted because a pilot project early in this study showed that rims are more likely than pillow cores to record a stable magnetization (Figure 4).

Samples were oriented in situ using a sun compass, checked with a magnetic compass. In the absence of sun, a second compass held away from the outcrop verified the absence of detrimental magnetic gradients. The 2.54 and $0.9 \mathrm{~cm}$ diameter cores were cut into specimens 2.25 and $0.8 \mathrm{~cm}$ in length, respectively.

Pillows selected had a spherical or oblate morphology which typically develop on horizontal or gently dipping surfaces [Ballard and Moore, 1977]. Orientations of pillow keel structures and sedimentary interbeds agreed and were used to obtain bedding attitudes and top directions. To minimize error, several estimates of strike and dip 


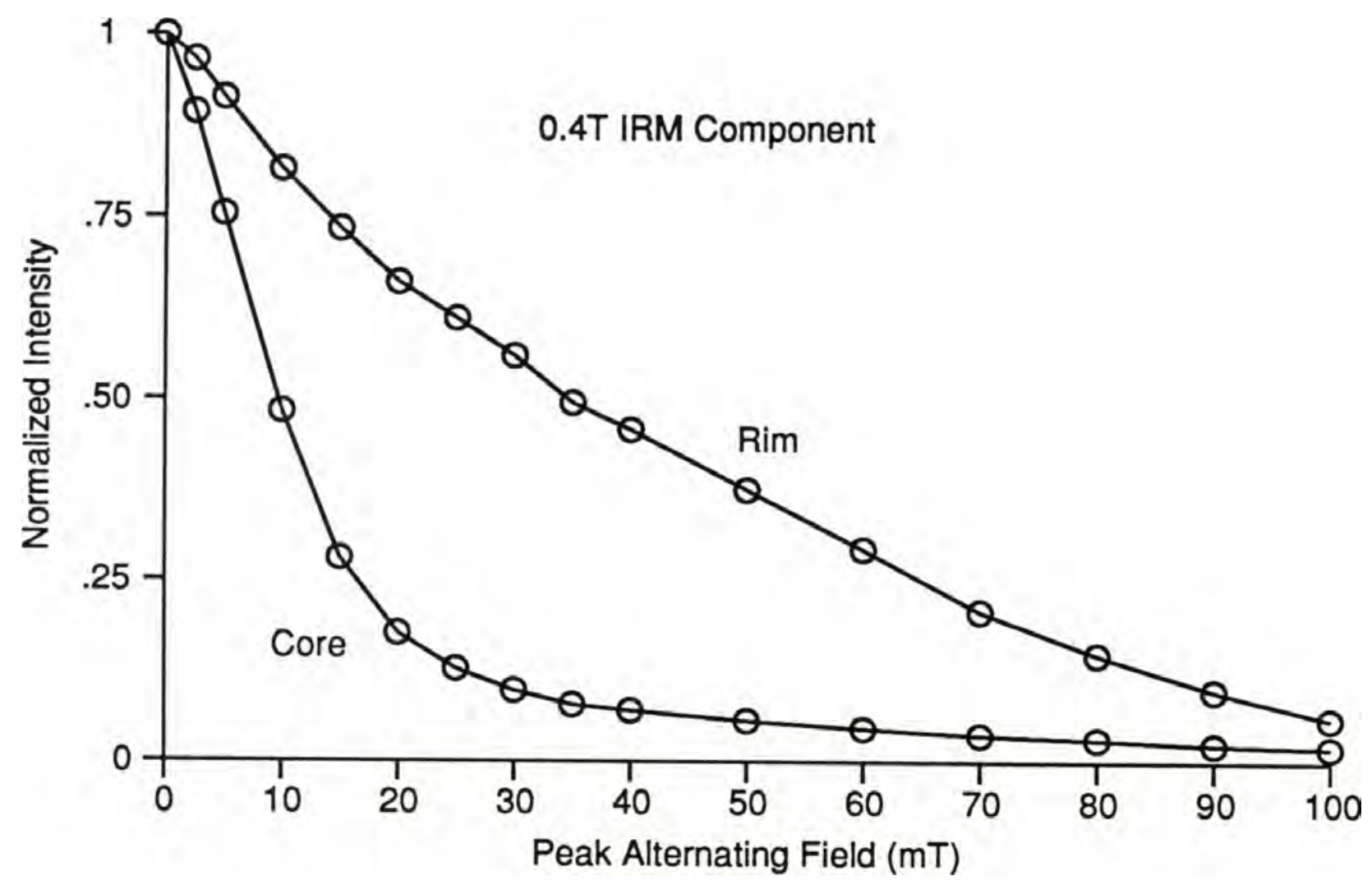

Figure 4: Stability of a $0.4 \mathrm{~T}$ isothermal remanent magnetization (IRM) to alternating field demagnetization for the rim and core of a single pillow. Samples were first given an IRM in a 1T field down the length of the specimen (z-axis), then in a $0.4 \mathrm{~T}$ field perpendicular to the $\mathrm{z}$-axis. This was done to isolate the component of magnetization which had coercivities matching those of the natural remanent magnetization. This diagram shows only the component of the axis that carries the 0.4T IRM. The rim shows a stable, nearly linear decay in magnetization with increased peak alternating field. The core, however, shows a rapid decrease by $20 \mathrm{mT}$ indicating that the remanence is carried primarily by low coercivity (unstable) minerals. 
were made at each site and averaged using Fisher [1953] statistics.

\section{Measurement and Demagnetization of NRM}

Measurements of magnetic remanence were made on a Schonstedt SSM-1a spinner magnetometer interfaced with a microcomputer. Four separate estimates of each of three orthogonal components of magnetization where made by measuring the specimen in six unique orientations. The specimen's direction and moment were calculated from the averages of these estimates. Reliability of the direction was calculated as $\gamma_{95}$ from the standard deviations of the estimates [Briden and Arthur, 1981]. Specimens with $\gamma_{95}$ greater than or equal to $15^{\circ}$ were rejected. $15^{\circ}$ was chosen as a critical value in order to filter out specimens with poorly defined magnetizations. Specimens had natural remanent magnetization (NRM) intensities ranging from $10^{-2}$ to $10^{2} \mathrm{~A} / \mathrm{m}$. The majority of specimens fell within the range of $10^{-1}$ to $1 \mathrm{~A} / \mathrm{m}$. One site's magnetization was weaker than the noise level of the magnetometer, and yielded no useful results.

To test stability and determine the blocking temperature spectra of the magnetizations, two pilot specimens (in most cases from the same core) from each site were subjected to two different types of progressive demagnetization: alternating field (AF) and thermal. The AF pilot specimens were demagnetized in a Schonstedt GSD-5 tumbling specimen demagnetizer at 15 levels between 10 and $100 \mathrm{mT}$. Thermal pilots were demagnetized in air at 13 levels between $100^{\circ}$ and $580^{\circ} \mathrm{C}$ in a custom-made magnetically-shielded oven. Oven calibration experiments established that temperatures are accurate to within $10^{\circ}$ below the set point. Before initial heating, and after 
each subsequent step, magnetic susceptibility was measured to monitor thermally induced changes in magnetic mineralogy. Because it appeared that the bulk of the magnetization was carried by a relatively high coercivity, fine-grained, Ti-poor titanomagnetite, all remaining specimens were thermally demagnetized with seven steps from $300^{\circ}$ to $585^{\circ} \mathrm{C}$.

\section{Analysis of NRM Demagnetization}

Magnetizations measured before and throughout progressive demagnetization, plotted as orthogonal projections of their vector endpoints [Zijderveld, 1967], define a demagnetization path. Linear segments of a specimen's demagnetization path probably reflect demagnetization of only one component of magnetization. Most specimens recorded two linear segments, one of which is interpreted as a relatively weak overprint that was not fully demagnetized until $200^{\circ}$ to $300^{\circ} \mathrm{C}$ (Figure 5). Directions of the stable components were determined using the free-line method of principal component analysis [Kirschvink, 1980] (Appendix). This method involves a linear transformation of the specimen's coordinate system to a new origin at the "center of mass" of the vector endpoints that define the selected linear segment of the demagnetization path. The resulting eigenvectors are in the directions of maximum, intermediate, and minimum variance. These variances correspond to the maximum, intermediate, and minimum eigenvalues which may be used to judge the linearity of the remanence. Their square roots yield standard deviations in each of the three directions, which are used to calculate the maximum angular deviation (MAD). $15^{\circ}$ was used as a critical value of MAD in order to filter out samples with unacceptably non-linear directions. 


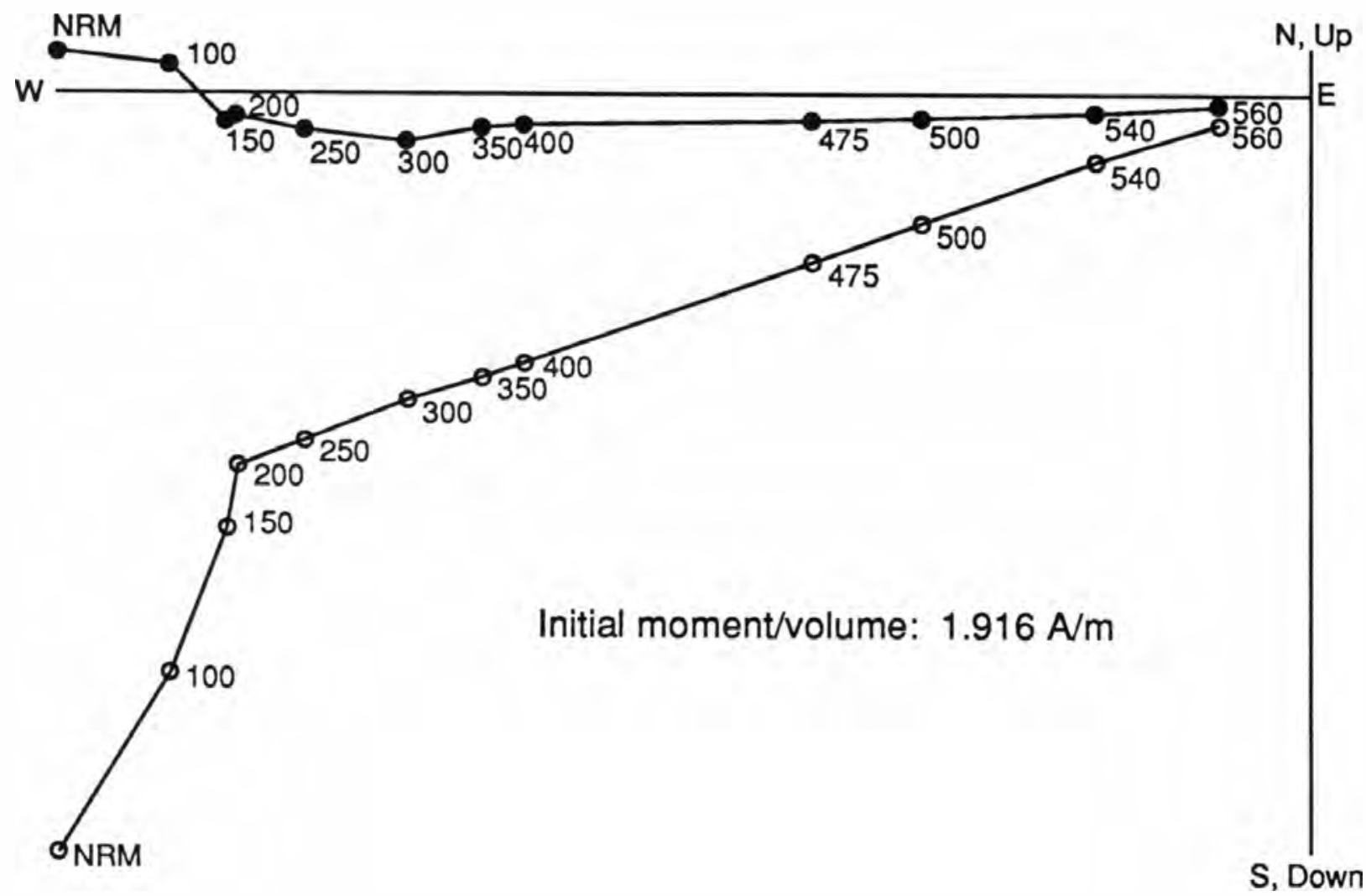

Figure 5: Orthogonal projection of thermal demagnetization path for specimen PM010101 showing removal of an overprint by approximately $300^{\circ} \mathrm{C}$. The free line method of principal component analysis [Kirschvink, 1980] allows the extraction of portions (in this case $350^{\circ}$ to $560^{\circ} \mathrm{C}$ ) of the demagnetization path without regard to other components that may be present. Closed circles: projection onto horizontal plane, Open circles: projection onto vertical west-east plane. 
Principal component analysis is equally applicable to directional datasets, each direction being a unit vector. The eigenvector in the direction of maximum variance is the least-squares best-fit direction. The intermediate and minimum eigenvectors correspond to the long and short axes of the distribution. MAD is a close approximation of angular standard deviation and is useful in describing dispersion. This averaging technique was used to provide eigenvalues required for a test of circularity and to quantify within-site dispersion.

The distribution of sample directions within each site was checked for circularity at the $95 \%$ confidence level using a method outlined by Schmidt [1990]. This was an aid in identifying sites possibly biased by a recent magnetization. This test involves the comparison of the ratio of the intermediate and minimum eigenvalues for $\mathrm{N}$ directions with tabulated critical values. With one exception, all sites that passed subsequent confidence tests had distributions that were circular at the $95 \%$ confidence level. Site PM03 had typical variation in inclination, but atypically small variation in declination (Figure 6). This apparent streaking may be due to minor differential rotations within the site or variable contributions from a minor stable secondary component of magnetization. Mean directions for all sites were calculated using Fisher's method [1953].

Sites were excluded if they had unusually large angular deviations (MAD $>15^{\circ}$ ) or mean directions with uselessly large confidence regions $\left(\alpha_{95}>15^{\circ}\right)$. Accepted site-mean directions were converted into virtual geomagnetic poles (VGPs) for comparison with reference poles. Structural correction of the site-mean directions involved rotating the in situ remanence directions to paleohorizontal about the local strike. 


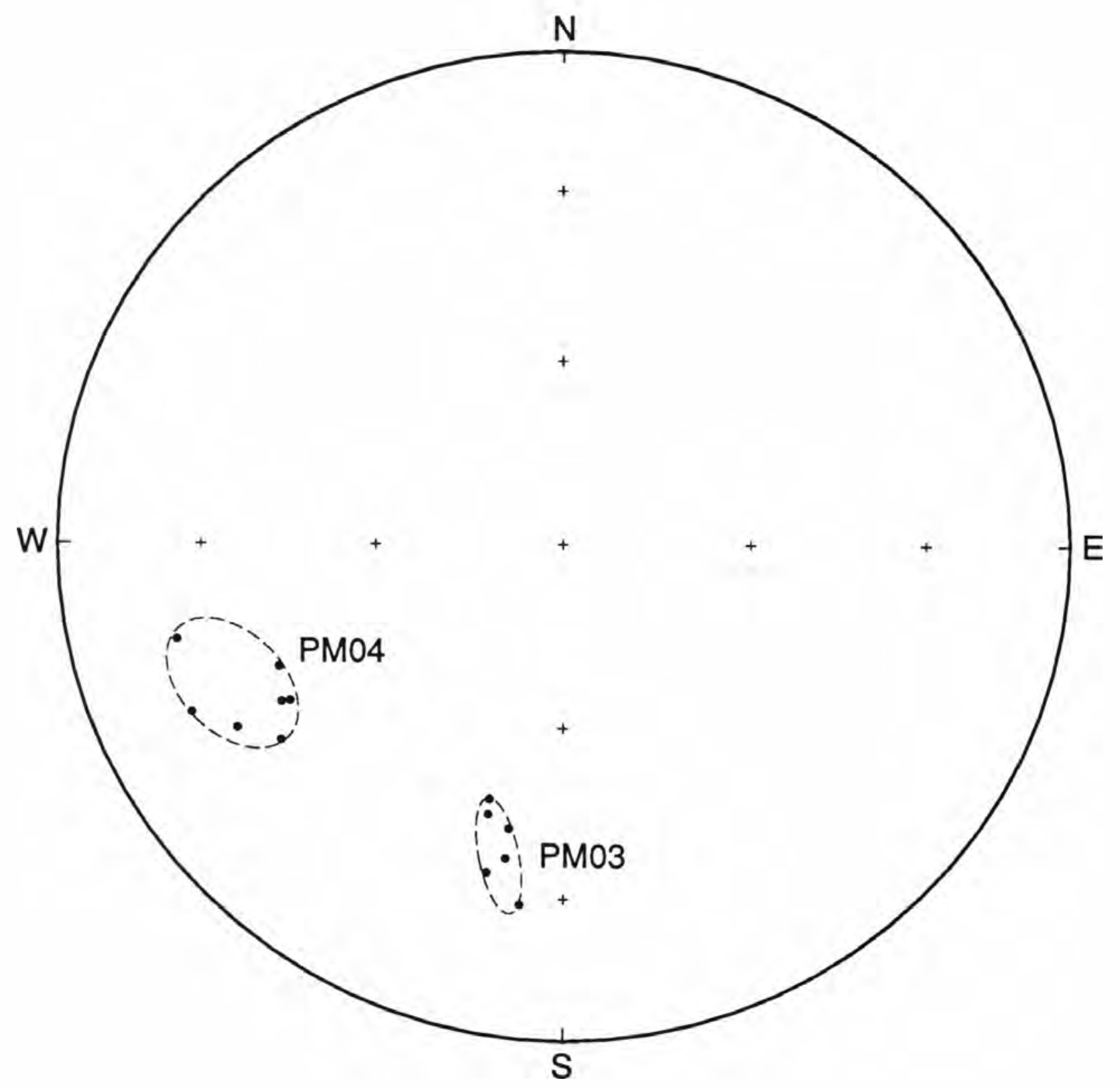

Figure 6: Equal-area projection of sample directions for two sites. The long and short axes of the ellipses are oriented in the directions of the intermediate and minimum eigenvalues. Site PM03 is the only site for which the hypothesis that the samples were drawn from a circular distribution can be rejected at the $95 \%$ confidence level [Schmidt, 1990]. All other sites, for example PM04, may appear elliptical, but due to the small number of sample directions the assumption that the distribution is circular cannot be rejected at the $95 \%$ confidence level. 
Correction of a plunging structure requires complex models and many assumptions [MacDonald, 1980]. An attempt was made to define a possible fold axis using structural data compiled from this study and the map of Tabor and Cady [1978a], however, large scatter of bedding plane poles (where top indicators were present) prevented an accurate determination. Correction for a possible plunging fold appears to be unnecessary because the site-mean VGPs are circularly distributed at the $95 \%$ confidence level [Schmidt, 1990].

\section{Paleomagnetic Directions}

Of the sites that passed confidence screenings, two sites (LS01 and PM06) were excluded from this study on the suspicion that they were sampled from recently rotated blocks. Site LS01 was located within the Mount Storm King landslide [Logan and Schuster, 1991] and site PM06 had a bedding orientation at a right angle to the orientations of adjacent sites. Site HR03 was excluded on suspicion of being completely remagnetized; its uncorrected direction was that of the present-day field. Site TP01, sampled by Moyer [1985], was included because it was Crescent basalt and techniques similar to those of this study were used for its analysis.

Paleomagnetic and structural data are summarized in Table 1. Using the test of McElhinny [1964], the reduction in scatter on correction for tilt is significant at the 95\% confidence level (Figure 7). Localities LS and MP have upward directions indicating that acquisition of magnetization spanned at least one reversal of the dipole field. Differences of site-mean directions obtained from adjacent flows were verified as significant using the test of McFadden and Lowes [1981]. Two sites at the HR 


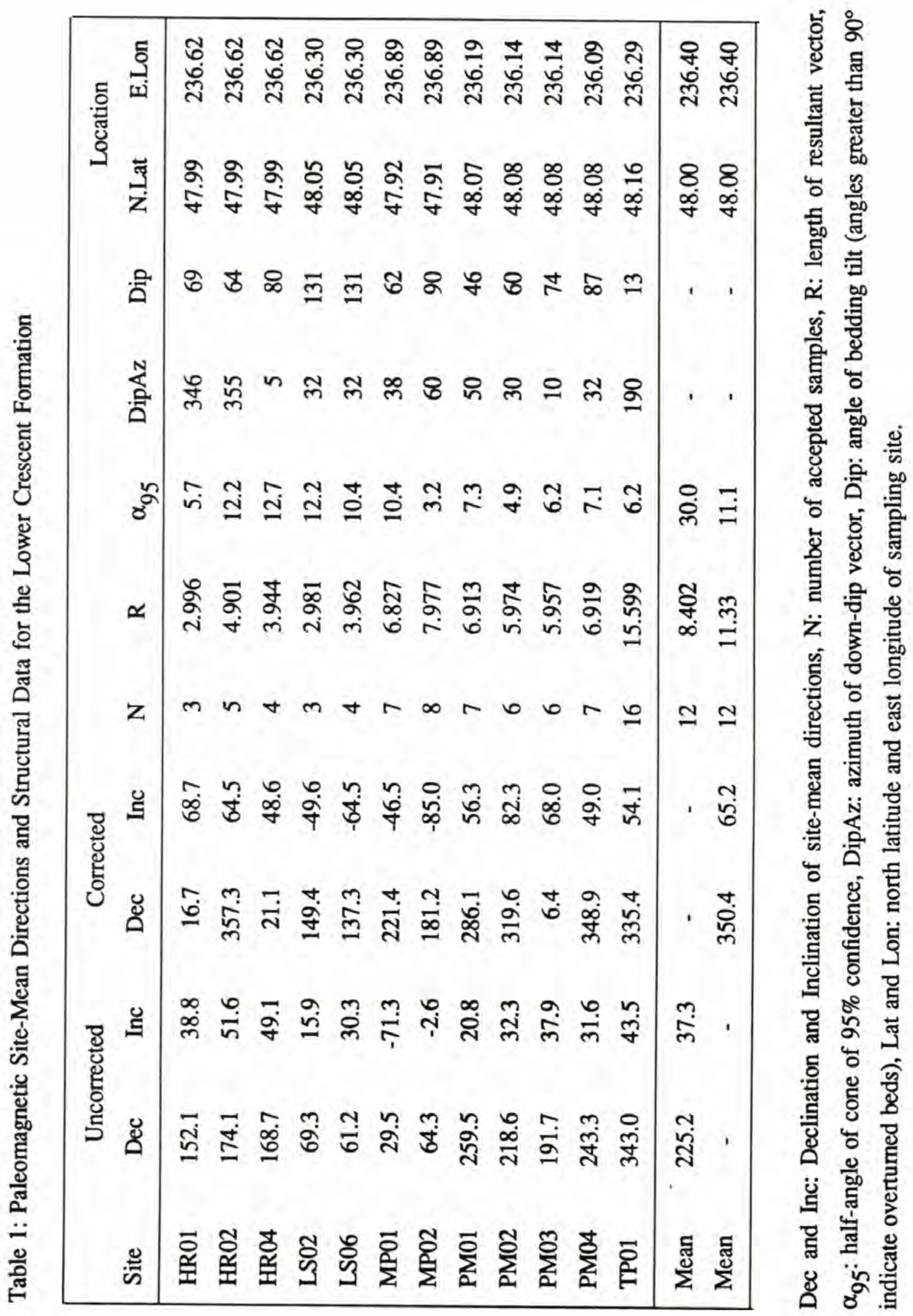




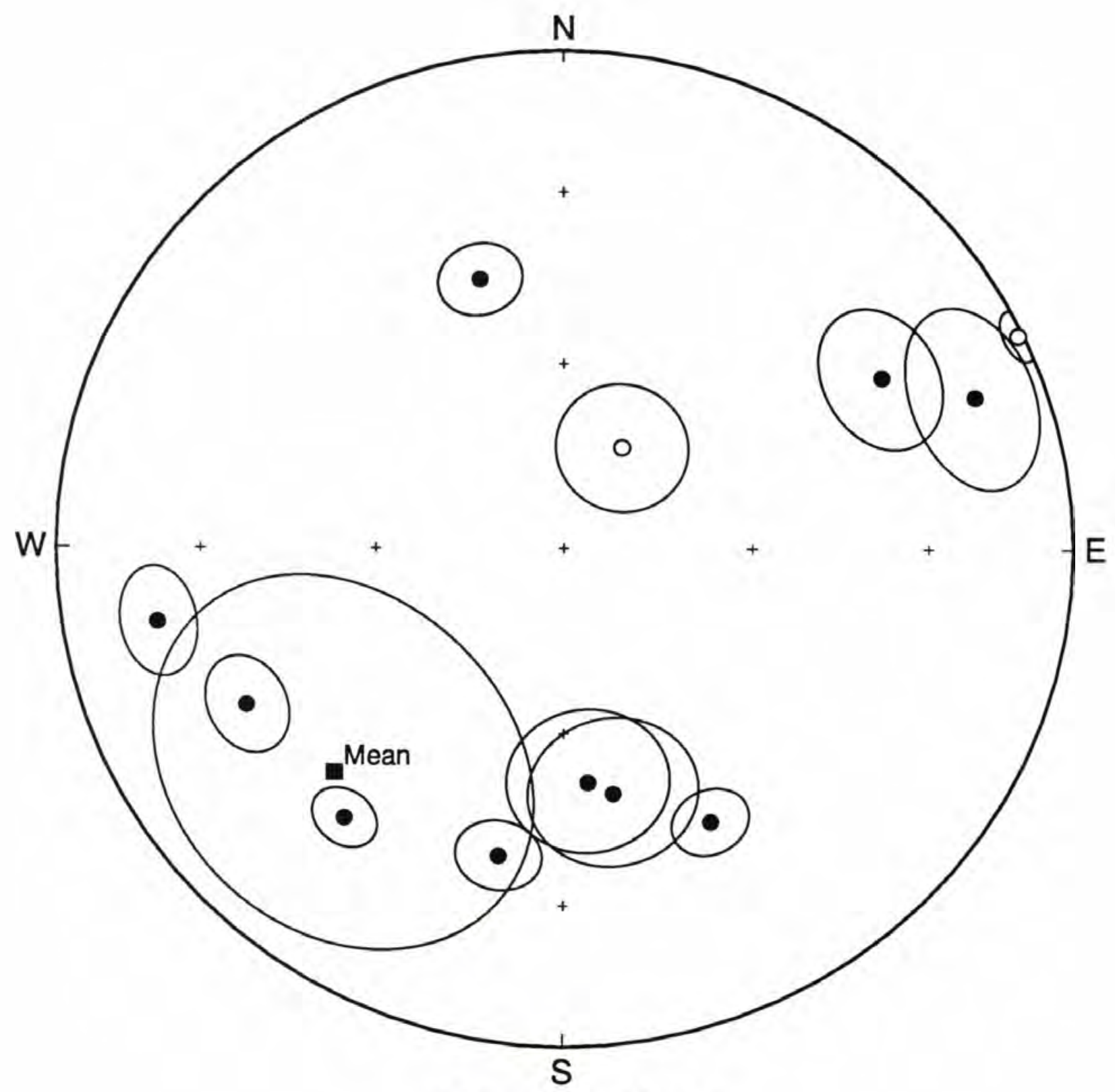

a) Uncorrected for Tilt

Figure 7: Equal-area projections of site-mean directions for the lower Crescent Formation before (a) and after (b) correction for bedding tilt. Closed symbols indicate downward directions and open symbols represent upward directions. Circles are $\alpha_{95}$. 


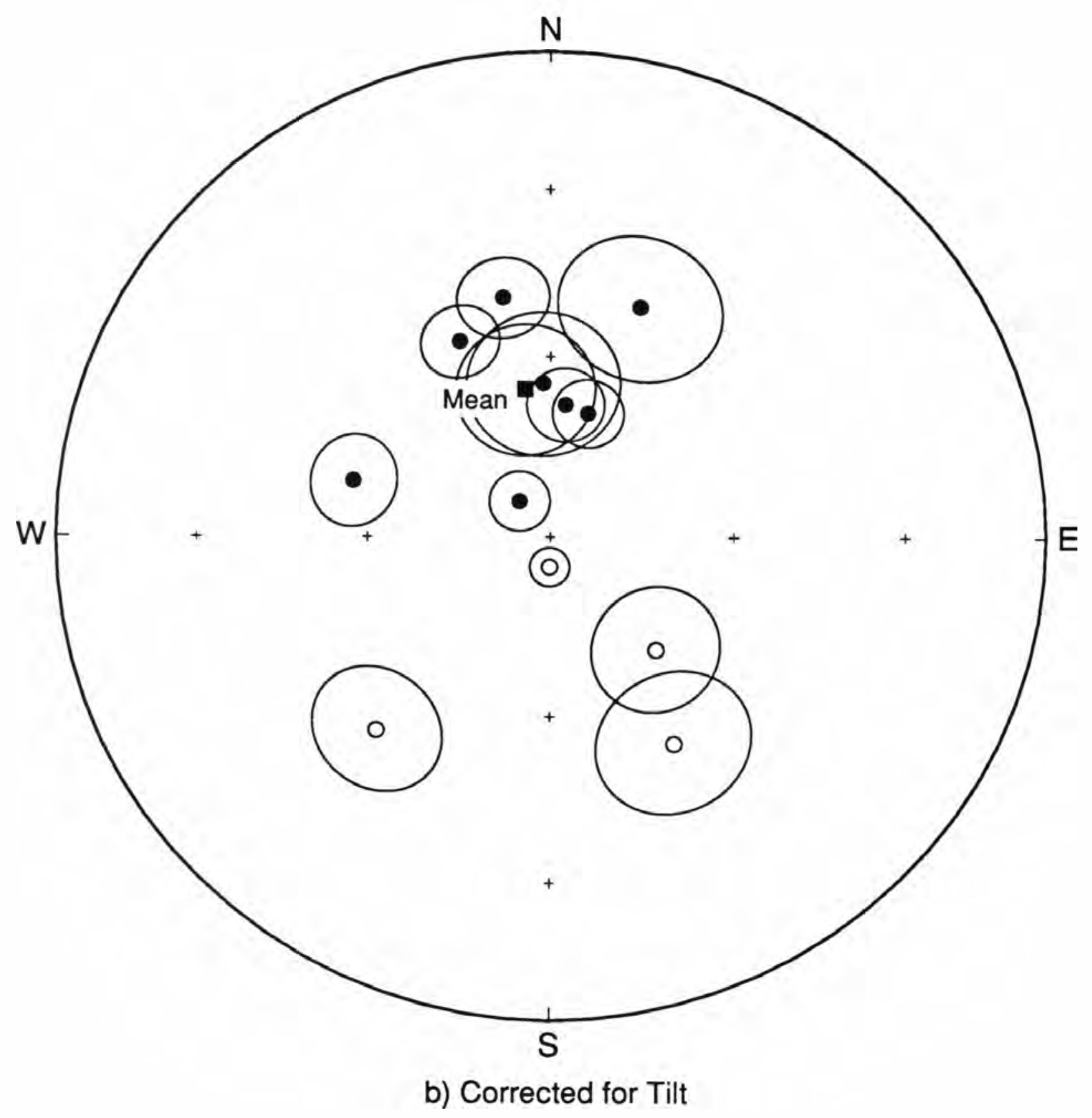


locality had indistinguishable directions at the $95 \%$ confidence level. This similarity appears to be fortuitous because two sites with significantly different magnetizations, yet having the same polarity, stratigraphically separate them.

Site-mean VGPs are circularly distributed at the $95 \%$ confidence level [Schmidt, 1990] but show large $\left(27^{\circ}\right)$ between-site dispersion; this will be discussed in the next section. The paleomagnetic pole obtained by averaging site-mean VGPs is $86.4^{\circ}$ north latitude, $170.0^{\circ}$ east longitude, and $A_{95}=16.5^{\circ}$. This is virtually identical to the $44-54$ Ma craton pole of Diehl and others [1983] (Table 3).

\section{Comparison with Previous Paleomagnetic Studies}

Results from this study were compared to previous work from the upper Crescent Formation [Beck and Engebretson, 1982; Purdy, 1987; Warnock, 1989] (Tables 2 and 3). Reexamination of the Mt. Walker (MW) locality of Warnock [1989] resulted in recalculation of the MW dataset. This dataset originally had been corrected assuming that two homoclinal sections were sampled. On reexamination, this appeared to be inappropriate for two sites. New independent structural corrections produce a more uniform distribution and no significant rotation (Table 3), which is consistent with the Bremerton (BR) subaerial exposures studied by Beck and Engebretson [1982] and Purdy [1987].

Although the Port Townsend/Port Ludlow (PT/PL) locality of Beck and Engebretson [1982], supplemented by Warnock [1989], records a possible counterclockwise rotation $\left(-17^{\circ} \pm 39^{\circ}\right)$, its mean is not significantly different from the expected direction (Table 3). A probable explanation is that single-level AF demagnetization (in the 
Table 2: Site-Mean Virtual Geomagnetic Poles for the Crescent Formation

\begin{tabular}{|c|c|c|c|c|c|}
\hline \multirow[b]{2}{*}{ Site } & \multirow[b]{2}{*}{$\mathrm{N}$} & \multicolumn{2}{|c|}{ Uncorrected } & \multicolumn{2}{|c|}{ Corrected } \\
\hline & & N.Lat & E.lon & N.Lat & E.Lon \\
\hline PL01 & 9 & -80.3 & 345.6 & -45.2 & 311.6 \\
\hline PL03 & 6 & -64.1 & 11.5 & -59.7 & 285.1 \\
\hline PT01 & 7 & -81.7 & 260.6 & -73.0 & 208.1 \\
\hline PT02 & 6 & -69.4 & 230.9 & -62.1 & 215.8 \\
\hline PT03 & 6 & -6.1 & 24.0 & -57.6 & 15.9 \\
\hline PT04 & 5 & -0.2 & 52.1 & -50.7 & 79.1 \\
\hline PT05 & 6 & -16.5 & 11.6 & -61.3 & 337.5 \\
\hline PT06 & 6 & -13.7 & 9.9 & -34.4 & 344.8 \\
\hline PT07 & 8 & -31.9 & 119.8 & -44.5 & 114.4 \\
\hline PT08 & 9 & -57.1 & 43.9 & -53.6 & 345.1 \\
\hline PT09 & 8 & 1.2 & 34.0 & -40.0 & 17.1 \\
\hline BR01 & 6 & -62.5 & 209.7 & -84.1 & 175.9 \\
\hline $\mathrm{BR} 02$ & 6 & -66.8 & 211.5 & -86.9 & 116.1 \\
\hline BR03 & 5 & -77.3 & 161.3 & -72.5 & 80.6 \\
\hline BR04 & 4 & -51.6 & 168.1 & -60.7 & 178.0 \\
\hline BR05 & 7 & -70.2 & 150.9 & -86.0 & 140.6 \\
\hline BR06 & 3 & -70.6 & 138.5 & -83.5 & 93.0 \\
\hline BR07 & 6 & -56.4 & 165.1 & -66.9 & 175.8 \\
\hline BR08 & 9 & -72.9 & 23.0 & -72.9 & 23.0 \\
\hline BR09 & 4 & -59.1 & 145.9 & -75.0 & 89.2 \\
\hline BR10 & 5 & -58.1 & 157.4 & -80.7 & 105.5 \\
\hline BR11 & 7 & -41.8 & 357.0 & -53.2 & 279.6 \\
\hline BR12 & 7 & -11.1 & 17.5 & -26.1 & 357.1 \\
\hline BR13 & 7 & -29.7 & 30.9 & -54.8 & 13.4 \\
\hline BR14 & 11 & -73.7 & 140.1 & -85.5 & 48.9 \\
\hline MW01 & 6 & -46.8 & 293.4 & -85.3 & 336.3 \\
\hline MW02 & 6 & 40.1 & 114.3 & 70.7 & 129.6 \\
\hline MW03 & 6 & 35.8 & 116.2 & 61.9 & 147.4 \\
\hline MW04 & 6 & 46.5 & 119.2 & 72.5 & 220.4 \\
\hline MW05 & 7 & 46.5 & 107.9 & 84.1 & 171.9 \\
\hline MW06 & 7 & 26.9 & 139.4 & 39.3 & 189.6 \\
\hline MW07 & 5 & 60.5 & 133.5 & 45.9 & 279.9 \\
\hline MW08 & 4 & 40.4 & 145.0 & 48.6 & 230.6 \\
\hline MW10 & 6 & 52.7 & 110.9 & 78.4 & 269.9 \\
\hline HR01 & 3 & -15.8 & 263.4 & 78.6 & 299.6 \\
\hline HR02 & 5 & -9.6 & 241.7 & 87.5 & 105.8 \\
\hline HR04 & 4 & -11.4 & 246.6 & 65.5 & 7.7 \\
\hline LSO2 & 3 & 19.8 & 336.5 & -60.8 & 300.4 \\
\hline LSO6 & 4 & 31.2 & 336.8 & -61.3 & 339.1 \\
\hline MP01 & 7 & -16.7 & 40.1 & -52.3 & 164.0 \\
\hline MP02 & 8 & 15.9 & 347.4 & -57.8 & 57.3 \\
\hline PM01 & 7 & 1.1 & 161.1 & 36.5 & 163.2 \\
\hline PM02 & 6 & -15.9 & 197.9 & 58.3 & 217.3 \\
\hline PM03 & 6 & -19.9 & 224.5 & 84.9 & 288.1 \\
\hline PM04 & 7 & -3.9 & 177.2 & 69.9 & 85.2 \\
\hline TP01 & 16 & 63.6 & 340.1 & 67.3 & 6.2 \\
\hline
\end{tabular}

$\mathrm{N}$ : number of accepted samples. 


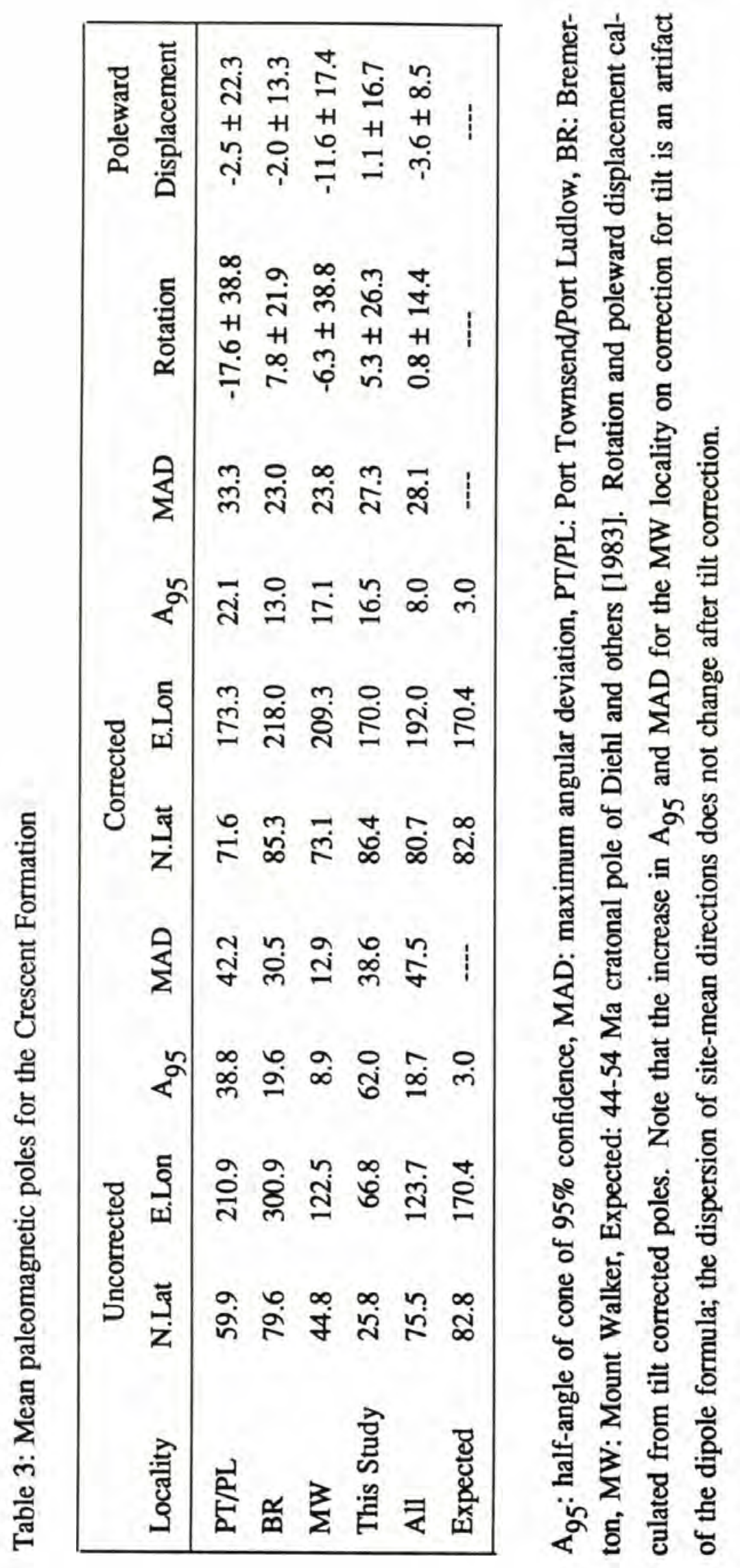


range of 10 to $30 \mathrm{mT}$ ) used in these earlier studies did not completely remove recent overprints.

A comparison of the paleomagnetic directions of different structural domains in and around the northern Olympic Mountains was undertaken to aid in the understanding of the deformation involved. This was facilitated because the basalts of the Crescent Formation were extruded and magnetized during the Eocene when apparent polar wander was relatively steady [Diehl et al., 1983]. Four essentially homoclinal structural domains (MW, BR, PT/PL, and this study) allowed the use of the fold test [McFadden and Jones, 1981] to determine whether the lower and upper Crescent Formation record a common dipole field. At the $95 \%$ confidence level, the four domains passed the fold test after correction for bedding tilt (Figure 8). In order to verify that the normal and reverse sites share a common mean, the reversal test of McFadden and Lowes [1981] also was applied. The data passed the test at the $95 \%$ confidence level after correction for tilt.

The observed $27^{\circ}$ of dispersion in the data from this study and the $28^{\circ}$ in the combined dataset is larger than one might expect from compilations of previous studies and a simple model of paleosecular variation [McFadden and McElhinny, 1984]: between $18^{\circ}$ and $20^{\circ}$ for latitude $48^{\circ}$ during the Eocene. However, the model of McFadden and McElhinny [1984] is based on studies with VGP distributions that have been arbitrarily screened for poles which lie at low to middle latitudes and may explain the observed discrepancy [Kristjansson and Johannesson, 1989]. Comparison with other paleomagnetic studies of the Oregon and Washington Coast Range basalts [Simpson and Cox, 1977; Globerman et al., 1982; Beck and Engebretson, 1982; Wells 


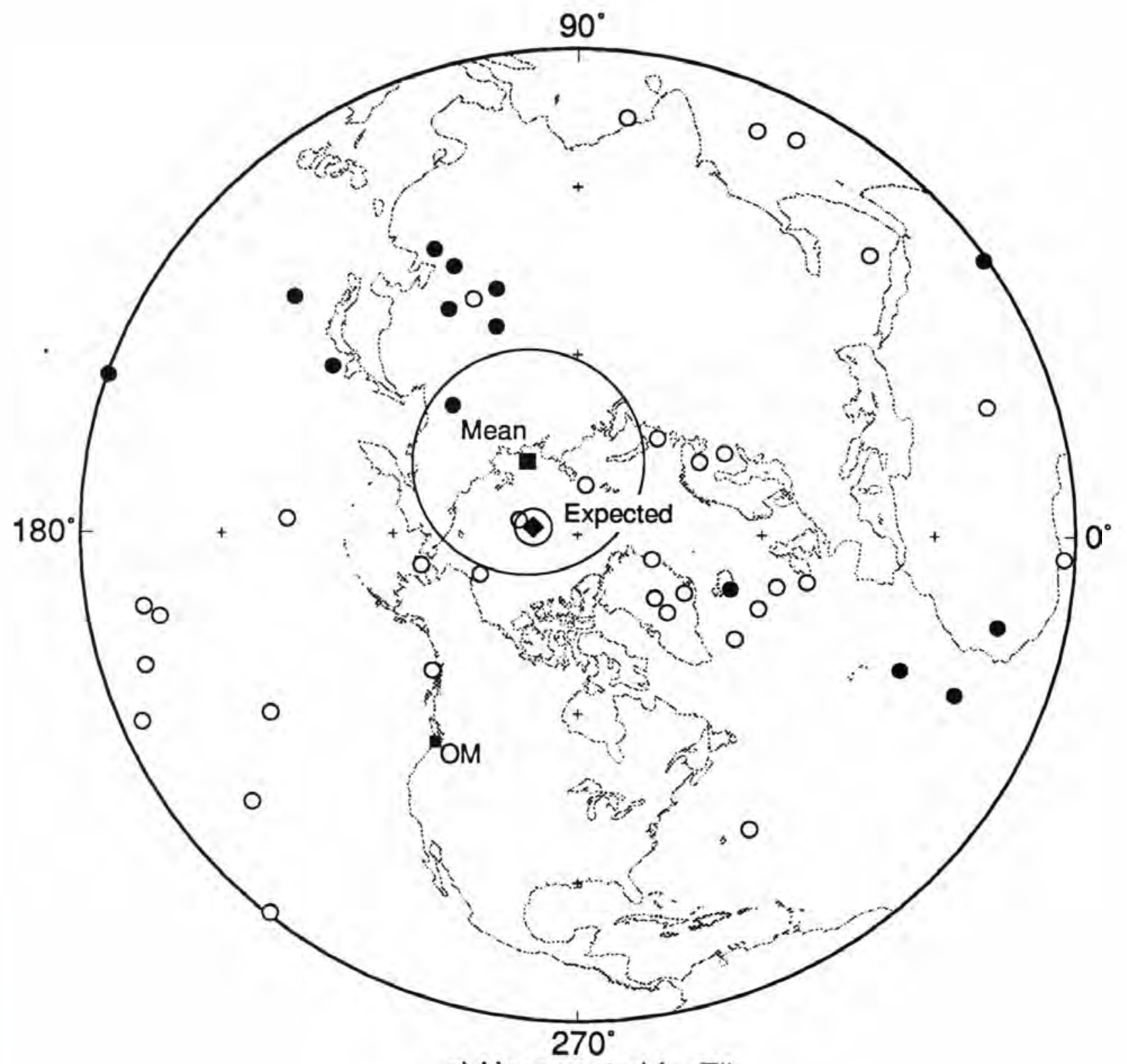

a) Uncorrected for Tilt

Figure 8: Equal-area polar projections of site-mean VGPs for the combined data from the Crescent Formation before (a) and after (b) correction for bedding tilt. The expected 44-54 Ma pole of Diehl and others [1983] (diamond) is also shown. Closed symbols indicate upper hemisphere poles and open symbols represent the antipoles of lower hemisphere VGPs. Circles are $\mathrm{A}_{95}$; OM: Olympic Mountains. 


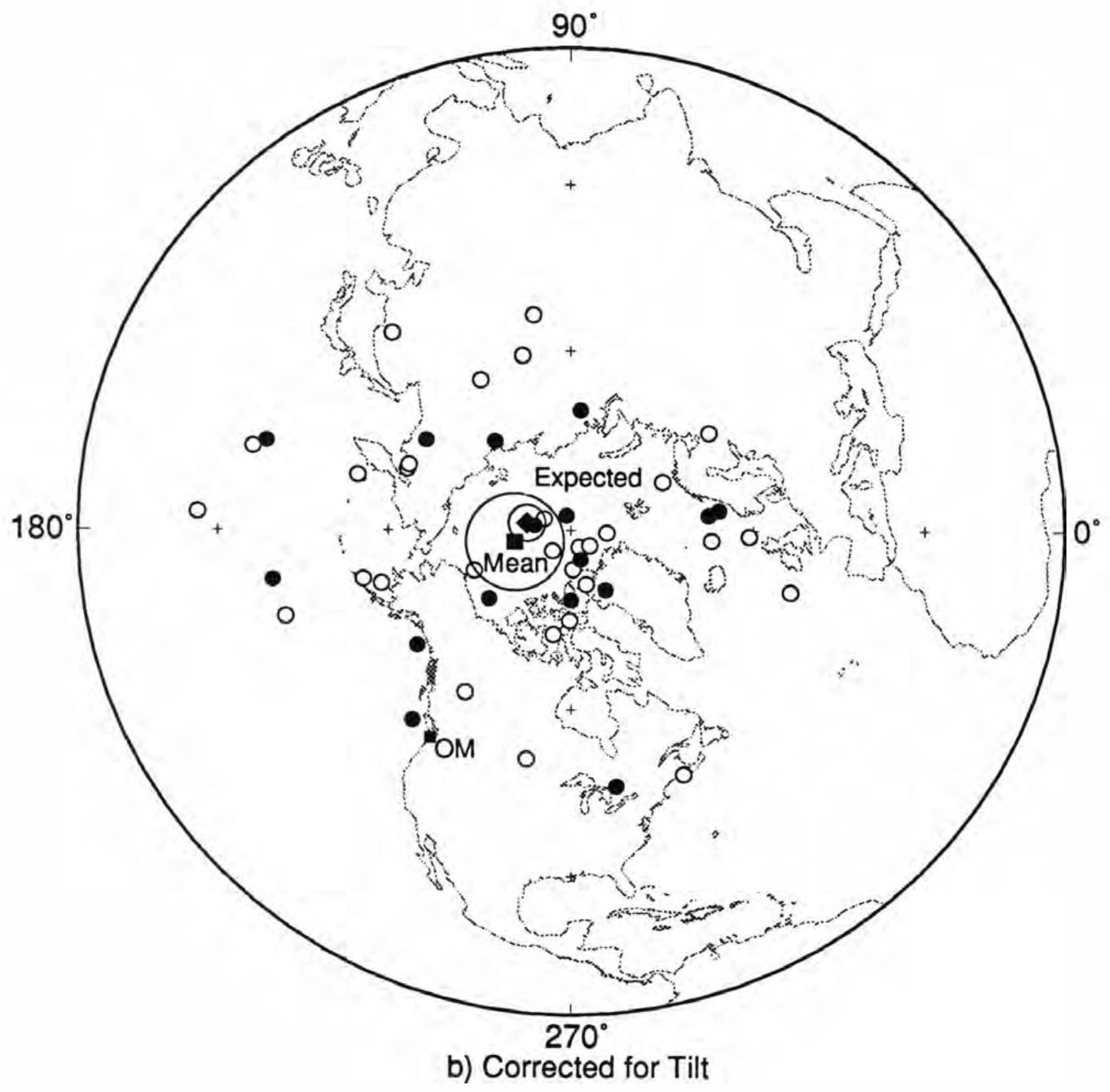


and Coe, 1985] reveals that large dispersions are typical.

Averaging the site-mean VGPs of all four domains appears to be a good approximation of the paleomagnetic pole for the northern and eastern sections of the Crescent Formation. Comparison of this mean pole with the pole expected for North America shows no significant discordance (Table 3; Figure 8).

\section{Timing of Acquisition of Magnetization}

Because a pre-deformational magnetization is not necessarily a primary magnetization [Burmester et al., 1990], a detailed analysis of the magnetic minerals is required in order to fully unravel the paleomagnetic history of the region. Geochemical results from the lower Crescent Formation indicate that the $\mathrm{TiO}_{2}$ content is slightly higher than expected for mid-oceanic ridge basalts [Babcock et al., 1992]. This high $\mathrm{TiO}_{2}$ content and observations from fresh pillows dredged from active mid-oceanic ridges [Irving, 1970; Irving et al., 1970] support the assumption that the primary magnetic phase was titanomagnetite. In addition, observation of polished thin sections from a pillow core reveals skeletal growth crystal morphologies (mostly cruciform) typical of rapidly quenched titanomagnetite (Figure 9). Under typical conditions of low temperature sea-floor alteration, titanomagnetite readily oxidizes to a metastable titanomaghemite [Ozdemir, 1987].

Two Curie temperature measurements were made from the rim and core of a single pillow [C.S. Grommé, personal communication, 1991]. Figure 10 shows the results of these measurements. The thermomagnetic curves show a behavior characteristic of pure magnetite with a minor amount of pyrrhotite in the rim of the pillow, 


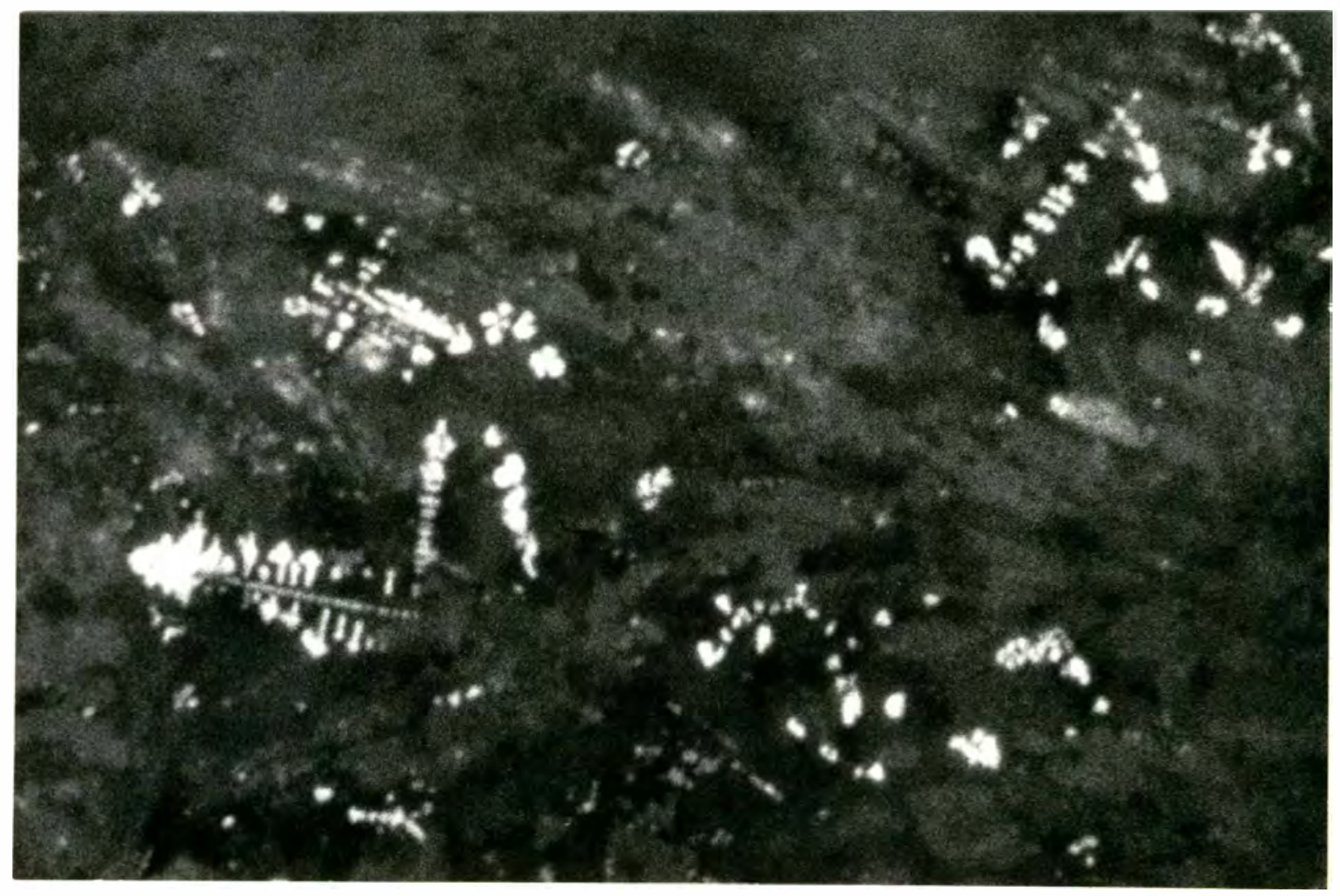

Figure 9: Photomicrograph of a polished thin section of a pillow core under reflected light. Skeletal growth crystal morphologies (cruciform type) are typical of rapidly quenched titanomagnetite [Haggerty, 1991]. The field of view is approximately 0.25 mm wide. 

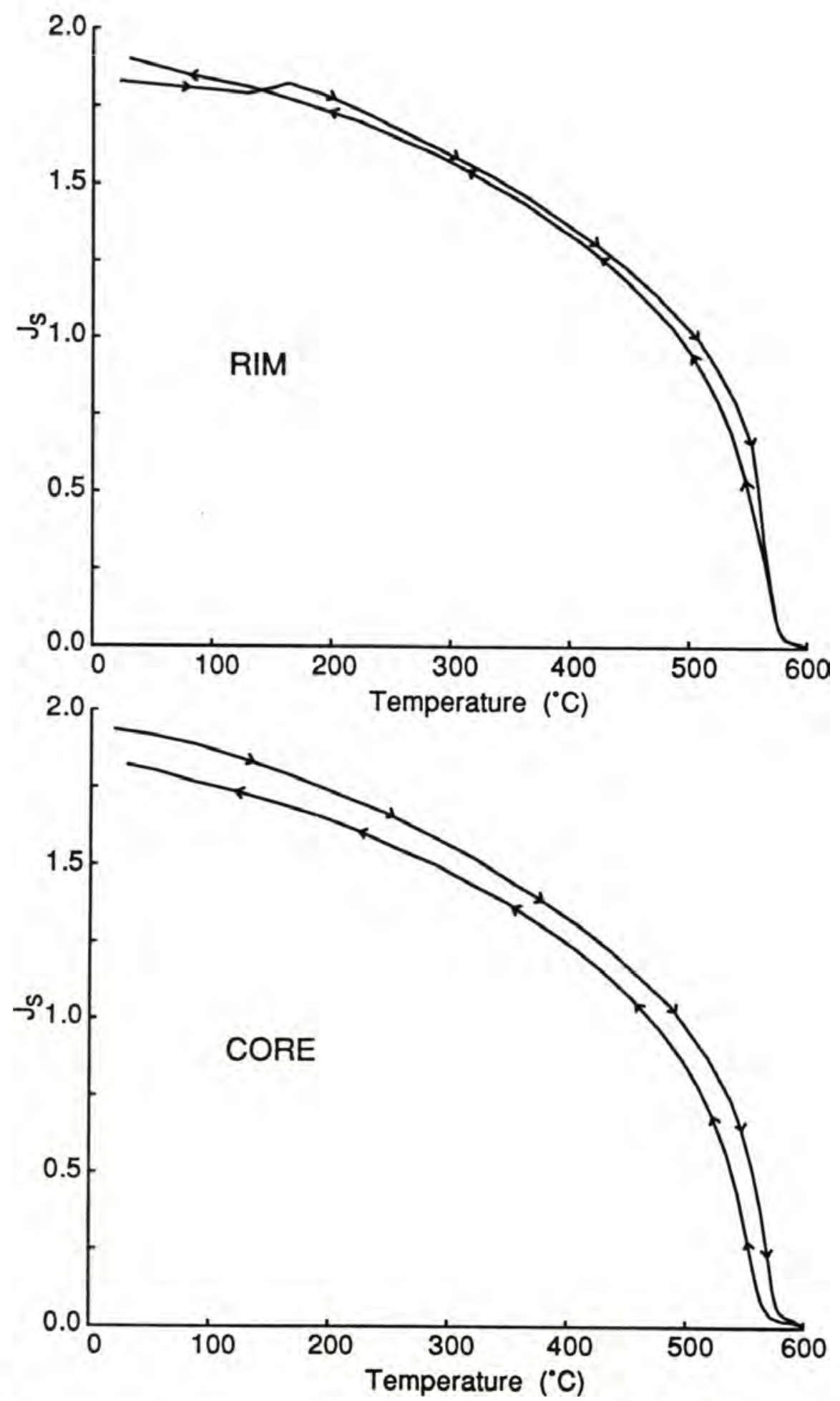

Figure 10: Thermomagnetic curves for the rim and core of a single pillow. Specimens were heated in a field of $232.2 \mathrm{mT}$. The curves are characteristic of essentially pure magnetite with a minor amount of pyrrhotite in the rim. Similarity between heating and cooling curves (as shown by arrows) indicates that there were negligible thermally-induced mineralogical changes. 
indicating that the magnetic minerals have been altered. The occurrence of pyrrhotite may be the result of a reducing environment either during cooling or reheating [Irving et al., 1970], while magnetite is likely the result of the inversion of titanomaghemite caused by reheating. Heating between approximately $250^{\circ}$ and $300^{\circ} \mathrm{C}$ (the approximate range for the prehnite-pumpellyite facies of metamorphism [Liou, 1971]) causes titanomaghemite to invert to ilmenite and a titanomagnetite which is magnetically indistinguishable from pure magnetite [Ozdemir, 1987]. Because of recrystallization caused by inversion, the primary direction of remanence was lost. The remanence observed, therefore, is most likely a chemical remanent magnetization (CRM) oriented parallel to the earth's field at the time of reheating.

There are two ways to achieve the prehnite-pumpellyite facies: sea-floor hydrothermal metamorphism [Alt et al., 1986] and burial metamorphism [Coombs et al., 1959]. Sea-floor metamorphism to the prehnite-pumpellyite facies may explain the metamorphism of the lower Crescent Formation; however, the base of the subaerial rocks of the upper Crescent Formation also is metamorphosed favoring burial. The presence of sedimentary rocks overlying the northern and eastern sections of the Crescent Formation indicates that burial was likely slow enough to have remagnetized each pillow flow at a distinct time, thus recording secular variation.

Subaerial basalts of the upper Crescent Formation appear to have a primary magnetization because analysis of polished thin sections reveals a texture which is characteristic of extreme oxidation [Haggerty, 1991] (Figure 11). High oxygen fugacity conditions during cooling produce the exsolution of titanomagnetite into Ti-rich and Tipoor phases; the Ti-rich phase then oxidizes to hematite and pseudobrookite [Grommé 


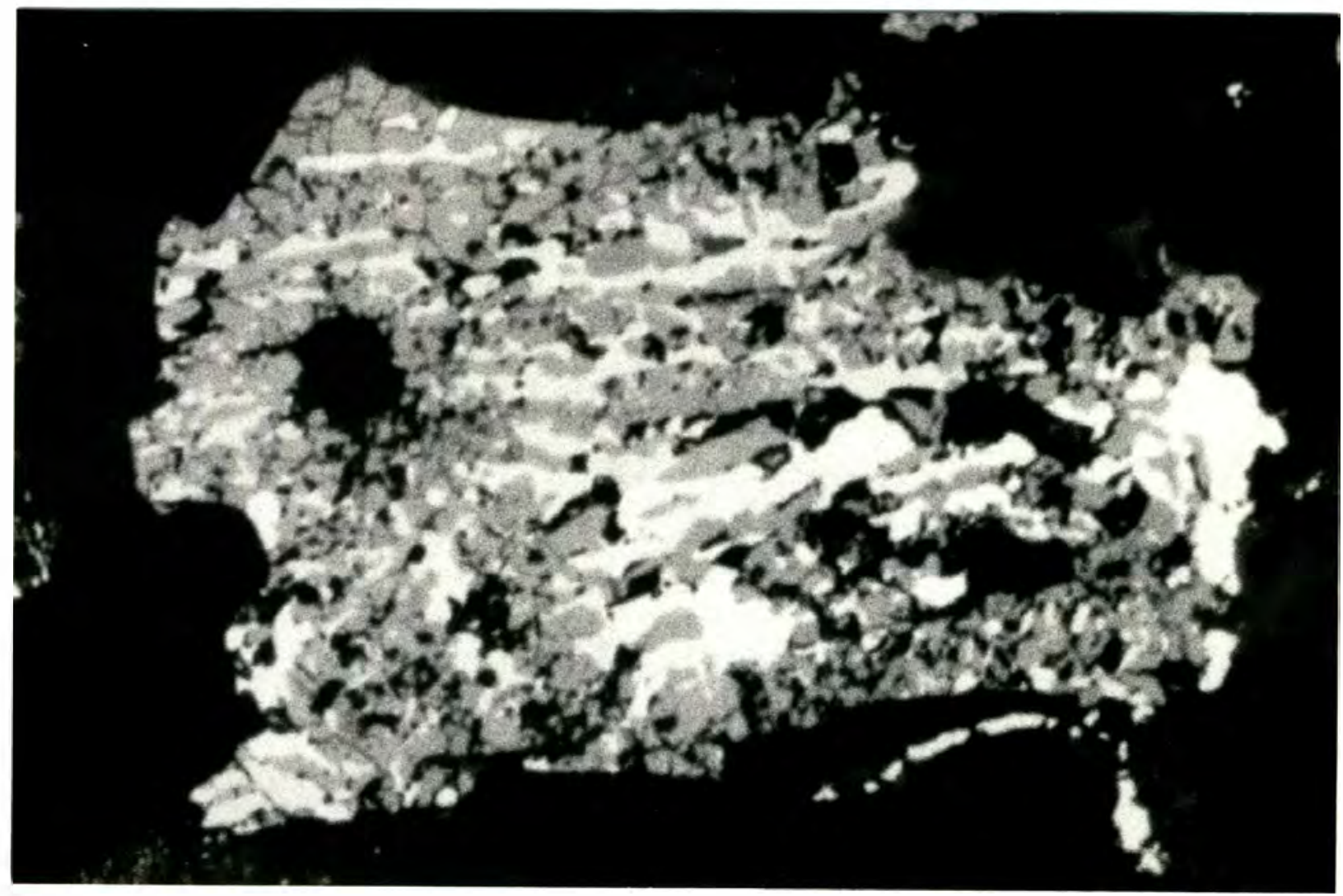

Figure 11: Photomicrograph of a polished thin section of a subaerial basalt from the upper Crescent Formation showing an extreme oxidation texture of titanomagnetite [Haggerty, 1991] under reflected light. High oxygen fugacity conditions during cooling result in exsolution of titanomagnetite into Ti-rich and Ti-poor phases. The Ti-rich phase readily oxidizes to hematite (white) and pseudobrookite (gray) [Grommé et al., 1969]. The field of view is approximately $0.25 \mathrm{~mm}$ wide. 
et al., 1969]. Rapid oxidation would explain why the Ti-poor phase and hematite share a single component of magnetization. Moreover, the presence of a single reverse direction, sandwiched between normally magnetized flows at the MW locality, is difficult to explain by total remagnetization. The magnetization of the upper Crescent Formation should have been unaffected by reheating because exsolution had already taken place raising the Curie temperature to $580^{\circ} \mathrm{C}$.

The successful multi-limb fold test between the upper and lower Crescent Formation indicates that they record a common dipole field before deformation. Assuming that the upper Crescent Formation records a primary magnetization, the lower Crescent Formation must have acquired a field-controlled CRM while still horizontal. Agreement between this CRM and the primary thermal remanent magnetization of gabbros of the Metchosin Igneous Complex on Vancouver Island [Irving and Massey, 1990], suggests that no major rotation occurred before remagnetization of the lower Crescent Formation. This agreement, however, is based on Irving and Massey's [1990] assumption that the entire exposure of the Metchosin Igneous Complex is approximately horizontal and is continuous with the Crescent Formation. Consistency between the primary magnetizations of the upper Crescent Formation and the Metchosin Igneous Complex favors their assumption.

In spite of the physical alteration of the Crescent basalts, the magnetization appears to be early, possibly primary. The paleomagnetic pole determined from the combined dataset is believed to be valid for tectonic analysis of the region. 


\section{REGIONAL TECTONICS}

\section{Deformation of the Crescent Formation}

Proposed models for the deformation of the Crescent Formation in the Olympic Mountains can be tested using paleomagnetism. The oroclinal bending model of Carey [1958] involves the folding of an originally linear trend of basalts about vertical axes.

Figure 12a illustrates the predicted distribution of paleomagnetic declinations after correction for bedding tilt about strike. The result shows a fanning of declinations which is not observed; therefore this model is dismissed. However, it should be noted that exposures south of Mount Walker (Figure 2) remain unconstrained paleomagnetically.

Erosion of a layered sequence deformed into an eastward-plunging antiform [Weaver, 1937] could have produced a curvature. If this were the appropriate model, structural correction solely for bedding tilt would have resulted in false rotations due to failure to correct for plunge [MacDonald, 1980] (Figure 12b). Because no such pattern is evident in the data, this model also can be rejected.

Erosion of a dome structure would also result in a curved outcrop pattern [Cady, 1975]. A domal uplift rotates bedding about horizontal axes (strike). Because correction for bedding tilts about their strike produces a circular distribution of VGPs, the simplest model that describes the deformation and is consistent with the paleomagnetic data, is a domal uplift. The outcrop pattern of the Crescent Formation does not display a complete circular dome; but is open to the west and southwest. An explanation for this configuration is that the northern and eastern sections represent two 

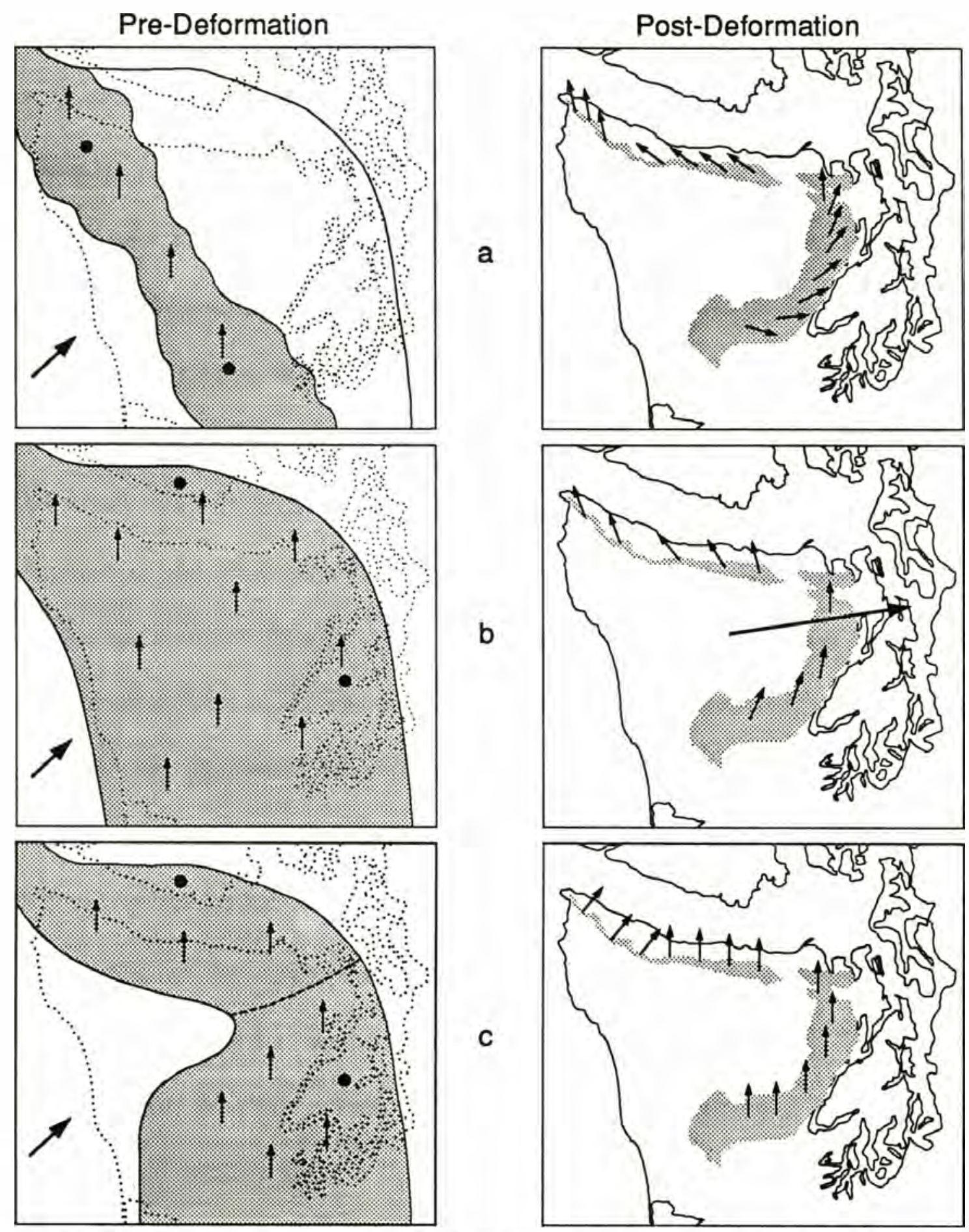

Figure 12: Predicted paleomagnetic declinations after correction for local bedding tilt about strike from models proposed for the deformation of the Crescent Formation (shaded region): (a) folding about a vertical axis [Carey, 1958]; (b) erosion of an eastward-plunging antiform [Weaver, 1937]; (c) erosion of a dome-like structure [Cady, 1975]. Solid circles in pre-deformation figures represent possible extrusion centers. Large arrows represent general plate motions; small arrows represent paleomagnetic declinations. Note that the sites shown in the southern Olympic Mountains have not yet been measured paleomagnetically. 
centers of extrusion [Cady, 1975] with flows thinning towards the west (Figure 12c). If this were the case, the present curvature may, in part, reflect a primary distribution of basalts.

Secondary components of magnetization from the sedimentary rocks of the northwestern Olympic Peninsula record a later deformational event which produced the approximate $40^{\circ}$ clockwise bend of the western tip of the Crescent Formation [Moyer, 1985] (Figure 12c). The western tip of the Crescent Formation appears to have been rotated (clockwise) towards the backstop created by Vancouver Island due to oblique convergence of the Farallon and/or Kula plates in conjunction with underthrusting of the subduction complex [Moyer, 1985]. Equivocal results were obtained from six sites near Kydikabbit Point at the far northwest end of the Olympic Peninsula (Figure 2). These sites were interpreted as retaining their primary remanence, showing a counterclockwise rotation of $70^{\circ}$ [Moyer, 1985]. This rotation may represent a local tectonic effect that requires further investigation to fully understand.

Formation of the subduction complex of the Olympic Core terrane must have included a large upward as well as a minor northeastward component. The northeastward component, possibly reflecting plate convergence, overturned the beds at the Lake Sutherland locality (Figure 2). Factors contributing to the upward component may include: isostatic rise of the relatively buoyant sediments of the subduction complex [Cady, 1975], upward arching of the down-going Juan de Fuca plate caused by the curved geometry of the trench [Brandon and Calderwood, 1990], or tectonic thickening during formation of the subduction complex [Cady, 1975; Davis and Hyndman, 1989]. Tectonic thickening is preferred because it is consistent with models describing 
the formation of accretionary wedges [Davis et al., 1983].

Davis and Hyndman [1989] applied the critically-tapered wedge model [Davis et al., 1983] to the Olympic Mountains. The shallow dip $\left(8^{\circ}\right.$ to $\left.10^{\circ}\right)$ of the subducting Juan de Fuca plate [Crosson and Owens, 1987] and the large supply of sediment migrating towards the embayment, perhaps aided by the northward component of plate convergence [Beck and Engebretson, 1982] (Figure 12c), permit the uplift of the accretionary prism to the elevation of approximately 2000 meters [Davis and Hyndman, 1989].

\section{Relation to Regional Paleomagnetic Rotations}

The concordant paleomagnetic pole determined from this study is consistent with the pole from uncorrected directions of the correlative Metchosin Igneous Complex on southern Vancouver Island [Irving and Massey, 1990], perhaps verifying their assumption that the entire exposure of the Metchosin Igneous Complex is approximately horizontal. Concordance also agrees with marginal rift-basin models involving in situ formation [Wells et al., 1984; Brandon and Massey, 1985; Massey, 1986; Clark, 1989; Babcock et al., 1992]. In contrast, the observation of no significant net rotation is anomalous for the Oregon and Washington Coast Ranges.

The lack of significant rotation could represent a history of equal and opposite rotations, but there is no geologic evidence for such rotations south of the Olympic Mountains. In addition, a complex history of rotation would have had to affect, to the same degree, both the steeply-dipping beds within the northern Olympic Mountains (this study) and the shallowly-dipping beds farther east (PT/PL and BR localities). 
Such structural cohesion has not been observed in the Crescent Formation of the Willipa Hills of southwestern Washington. Rather, they appear to have been differentially rotated between closely spaced structural domains [Wells and Coe, 1985] (Figure 1).

No rotation may simply represent the lack of a rotational mechanism. Wells and Heller [1988] developed a model that describes the rotations of the Coast Ranges. $60 \%$ of the rotation was attributed to differential north-south extension of the Basin and Range Province [Simpson and Cox, 1977; Magill et al., 1981; Heller, 1983; Frei et al., Grommé et al., 1986], and $40 \%$ was due to non-rigid dextral shear caused by coupling during oblique convergence [Beck, 1976, 1980]. Given the possibility that the Olympic Mountains were north of the influence of the Basin and Range Province, a significant proportion of the rotational mechanism (oblique convergence) may still have been present. Factors unique to the area may have prevented rotation. The east-west trending Clallam syncline just north of the Olympic Mountains (Figure 2) indicates that north-south shortening of the Coast Range basalts in northwestern Washington is accommodated by large-scale folding as well as faulting. Southern Vancouver Island possibly acted as a backstop restricting major northward displacement or rotation of the northern Crescent Formation [Beck and Engebretson, 1982]. 


\section{CONCLUSIONS}

Previous paleomagnetic studies of the basalts of the lower Crescent Formation have failed. The discovery that rims are more likely than pillow cores to record a stable magnetization and the use of a small-diameter core drill, which allowed the sampling of these fractured rims, contributed greatly to the success of this study.

Three conclusions can be drawn from the paleomagnetic analysis. First, the stable remanent magnetization measured within the Crescent Formation appears to be early, before significant deformation and possibly primary. This conclusion is based on rock-magnetic evidence suggesting that the subaerial basalts of the upper Crescent Formation retained their primary remanence. A positive multi-limb fold test between exposures of the upper and lower Crescent Formation indicates that the remanence in the lower Crescent was likely acquired early and while horizontal.

Second, correction for bedding rotations about strike at four different structural domains produces a circular distribution of VGPs. The simplest model which fits the paleomagnetic data is a dome-like uplift of the Olympic Mountains that was likely the result of tectonic thickening during the formation of the subduction complex of the Olympic Core terrane [Cady, 1975; Davis and Hyndman, 1989]. Shallow subduction and a continuous sediment supply, perhaps aided by the northward component of plate convergence, allowed the uplift [Davis and Hyndman, 1989].

Third, the northern Crescent Formation shows no significant net rotation. This concordance agrees with the in situ results from the Metchosin Igneous Complex studied by Irving and Massey [1990]. Concordance is also in agreement with models 
which describe the extrusion of the Crescent basalts in a marginal rift-basin [Wells et al., 1984; Brandon and Massey, 1985; Massey, 1986; Clark, 1989; Babcock et al., 1992]. The Olympic Mountains may have been located north of the influence of Basin and Range extension, eliminating more than half of the mechanism of rotation predicted by the model of Wells and Heller [1988]. In addition, southern Vancouver Island may have acted as a backstop, thereby inhibiting major northward displacement and rotation [Beck and Engebretson, 1982]. Regardless of the mechanisms, the results presented here demonstrate that the northern Olympic Mountains have experienced a deformational history different from correlative Coast Range exposures to the south. 


\section{REFERENCES}

Alt, J.C., Honnorez, J., Laverne, C., and Emmerman, R., Hydrothermal alteration of a $1 \mathrm{~km}$ section through the upper oceanic crust, deep sea drilling project hole 504b: mineralogy, chemistry, and evolution of seawater-basalt interactions, J. Geophys. Res., 91, 10309-10335, 1986.

Babcock, R.S., Warnock, A.C., and Engebretson, D.C., The composition and tectonic setting of the Crescent basalts and related rocks, Olympic Peninsula, Washington, (abstract), EOS Trans. AGU, 72, 600, 1991.

Babcock, R.S., Burmester, R.F., Warnock, A.C., Engebretson, D.C., and Clark, K.P., A rifted margin origin for the Crescent Basalts and related rocks in the northern Coast Range Volcanic Province, Washington and British Columbia, J. Geophys. Res., in press, 1992.

Ballard, R.D., and Moore, J.G., Photographic Atlas of the Mid-Atlantic Ridge Rift Valley, Springer-Verlag, New York, 114 pp., 1977.

Beck, M.E., Jr., Discordant paleomagnetic pole positions as evidence of regional shear in the western Cordillera of North America, Am. J. Sci., 276, 694-712, 1976.

Beck, M.E., Jr., Paleomagnetic record of plate processes along the western edge of North America, J. Geophys. Res., 85, 7115-7131, 1980.

Beck, M.E., Jr., Paleomagnetism of continental North America; Implications for displacement of crustal blocks within the Western Cordillera, Baja California to British Columbia, in Geophysical Framework of the Continental United States, edited by L.C. Pakiser and W.D. Mooney, Mem. Geol. Soc. Am., 172, 471-492, 1989.

Beck, M.E., Jr. and Engebretson, D. C., Paleomagnetism of small basalt exposures in the west Puget Sound area, Washington, and speculations on the accretionary origin of the Olympic Mountains, J. Geophys. Res., 87, 3775-3760, 1982.

Beske-Diehl, S.J., Magnetization during low-temperature oxidation of sea-floor basalts: no large scale chemical remagnetization, J. Geophys. Res., 95, 21413-21432, 1990.

Brandon, M.T., and Calderwood, A.R., High-pressure metamorphism and uplift of the Olympic subduction complex, Geology, 18, 1252-1255, 1990.

Brandon, M., and Massey, N.W.D., Early Tertiary tectonics of the Pacific Northwest: Truncation and rifting with a transform plate boundary, in Symposium on the Deep Structure of Southern Vancouver Island, Results of LITHOPROBE Phase 1, Geol. Assoc. Can. Program Abstr., 8, 9, 1985.

Briden, J.C., and Arthur, G.R., Precision of measurement of remanent magnetization, Can. J. Earth Sci., 18, 527-538, 1981.

Burmester, R.F., Bazard, D.R., and Beck, M.E., Jr., Post-folding remagnetization that passes the fold test, Geophys. J. R. Astron. Soc., 102, 455-463, 1990.

Cady, W.M., Tectonic setting of the Tertiary volcanic rocks of the Olympic Peninsula, Washington, J. Resour. U.S. Geol. Surv., 3, 573-582, 1975. 
Cady, W.M., Tabor, R.W., MacLeod, N.S., and Sorensen, M.L., Geology of the Tyler Peak quadrangle, Washington, U.S. Geol. Surv. Quad. Map GQ-970, scale $1: 62,500,1972$.

Carey, S.W., The tectonic approach to continental drift, in Continental Drift, a Symposium, edited by S.W. Carey, Hobart, Tasmania, 177-355, 1958.

Clark, K.C., Comparative stratigraphy, petrology, and geochemistry of the Crescent Formation and related exposures near Bremerton and Port Townsend, Washington, M.S. thesis, Western Washington University, Bellingham, Washington, 171 pp., 1989.

Clowes, R.M., Brandon, M.T., Green, A.G., Yorath, C.J., Sutherland-Brown, A., Kanasewich, E.R, and Spencer, C., LITHOPROBE-southern Vancouver Island: Cenozoic subduction complex imaged by deep seismic reflections, Can. J. Earth Sci, 24, 31-51, 1987.

Coombs, D.S., Ellis, A.J., Fyfe, W.S., and Taylor, A.H., Lower grade mineral facies in New Zealand, 21st Int. Geol. Congr., Copenhagen, 13, 339-351, 1960.

Crosson, R.S., and Owens, T.J., Slab geometry of the Cascadia subduction zone beneath Washington from earthquake hypocenters and teleseismic converted waves, Geophys. Res. Lett., 14, 824-827, 1987.

Davis, D., Suppe, J., and Dahlen, F.A., Mechanics of fold-and-thrust belts and accretionary wedges, J. Geophys. Res., 88, 1153-1172, 1983.

Davis, E.E., and Hyndman, R.D., Accretion and recent deformation of sediments along the northern Cascadia subduction zone, Geol. Soc. Am. Bull., 101, 1465-1480, 1989.

Diehl, J.F., Beck, M.E., Jr., Beske-Diehl, S., Jacobson, D., and Hearn, B.C., Paleomagnetism of the Late Cretaceous-Early Tertiary north-central Montana alkalic province, J. Geophys. Res., 88, 10593-10609, 1983.

Duncan, R.A., A captured island chain in the Coast Range of Oregon and Washington, J. Geophys. Res., 87, 10827-10837, 1982.

Einarsen, J.M., and Engebretson, D.C., Constraints on the origin and travel of the Crescent and Siletz terranes from plate kinematics, Geol. Soc. Am. Abstr. Programs, 19, 375, 1987.

Engebretson, D.C., Gordon, R.G., and Cox, A., Relative motions between oceanic and continental plates of the Pacific Basin, Spec. Pap. Geol. Soc. Am., 206, 59 pp., 1985.

Fisher, R.A., Dispersion on a sphere, Proc. R. Soc. London, Ser. A, 217, 295-305, 1953.

Frei, L.S., Magill, J.R., and Cox, A., Paleomagnetic results from the central Sierra Nevada: Constraints on reconstructions of the western United States, Tectonics, 3, 157-178, 1984.

Glassley, W.E., Geochemistry and tectonics of the Crescent volcanic rocks, Olympic Peninsula, Washington, Geol. Soc. Am. Bull., 93, 785-794, 1974. 
Globerman, B.R., Beck, M.E., Jr., and Duncan, R.A., Paleomagnetism and tectonic significance of Eocene basalts of the Black Hills, Washington Coast Range, Geol. Soc. Am. Bull., 93, 1151-1159, 1982.

Gower, H.D., Geology of the Pysht Quadrangle, Washington, U.S. Geol. Surv. Map GQ-129, scale 1:62,500, 1960.

Grommé, C.S., Wright, T.L., and Peck, D.L., Magnetic properties and oxidation of iron-titanium oxide minerals in Alae and Makaopuhi Lava Lakes, Hawaii, J. Geophys. Res., 74, 5277-5293, 1969.

Grommé, C.S., Beck, M.E., Jr., Wells, R.E., and Engebretson, D.C., Paleomagnetism of the Tertiary Clarno Formation of central Oregon and its significance for the tectonic history of the Pacific Northwest, J. Geophys. Res., 91, 14089-14103, 1986.

Haggerty, S.E., Oxide textures - a mini-atlas, in Oxide Minerals: Petrologic and Magnetic Significance, edited by D.H. Lindsley, Min. Soc. Am., 25, 129-219, 1991.

Irving, E., The Mid-Atlantic Ridge at $45^{\circ} \mathrm{N}$. XIV. Oxidation and magnetic properties of basalt; review and discussion, Can. J. Earth Sci., 7, 1528-1538, 1970.

Irving, E., Park, J.K., Haggerty, S.E., Aumento, F., and Loncarevic, B., Magnetism and opaque mineralogy of basalts from the Mid-Atlantic Ridge at $45^{\circ} \mathrm{N}$, Nature, 228 , 974-976, 1970.

Irving, E., and Massey, N.W.D., Paleomagnetism of ocean layers 2 and 3, evidence from the Metchosin Complex, Vancouver Island, Phys. Earth Planet. Int., 64, 247-260, 1990.

Kirschvink, J., The least-squares line and plane and the analysis of paleomagnetic data, Geophys. J. R. Astron. Soc., 62, 699-718, 1980.

Kristjansson, L., and Johannesson, H., Variable dispersion of Neogene geomagnetic field directions in Iceland, Phys. Earth Planet. Int., 56, 124-132, 1989.

Liou, J.G., Synthesis and stability relations of prehnite, $\mathrm{Ca}_{2} \mathrm{Al}_{2} \mathrm{Si}_{3} \mathrm{O}_{10}(\mathrm{OH})_{2}, A m$. Mineral., 56, 507-531, 1971.

Logan, R.L., and Schuster, R.L., Lakes divided: The origin of Lake Crescent and Lake Sutherland, Clallam County, Washington, Washington Geology, 19, 38-42, 1991.

MacDonald, W.D., Net tectonic rotation, apparent tectonic rotation and the structural tilt correction in paleomagnetic studies, J. Geophys. Res., 85, 3670-3680, 1980.

Magill, J.R., Cox, A.V., and Duncan, R.A., Tillamook volcanic series: Further evidence of tectonic rotation in the Oregon Coast Range, J. Geophys. Res., 86, 2953-2970, 1981.

Massey, N.W.D., Metchosin Igneous Complex, southern Vancouver Island: ophiolite stratigraphy developed in a emergent island setting, Geology, 7, 602-605, 1986.

McElhinny, M.W., Statistical significance of the fold test in paleomagnetism, Geophys. J. R. Astron. Soc., 8, 338-340, 1964. 
McFadden, P.L., and Jones, D.L., The fold test in paleomagnetism, Geophys. $J . R$. Astron. Soc., 67, 53-58, 1981.

McFadden, P.L., and Lowes, F.J., The discrimination of mean directions drawn from Fisher distributions, Geophys. J. R. Astron. Soc., 67, 19-33, 1981.

McFadden, P.L., and McElhinny, M.W., A physical model for palaeosecular variation, Geophys. J. R. Astron. Soc., 78, 809-830, 1984.

Moyer, R.D., Paleomagnetism of the Tertiary rocks of the northern Olympic Peninsula, Washington, and its implications, M.S. thesis, Western Washington University, Bellingham, Washington, 154 pp., 1985.

Ozdemir, O., Inversion of titanomaghemites, Phys. Earth Planet. Int., 46, 184-196, 1987.

Purdy, J.W., Paleomagnetism and tectonic interpretation of the Crescent and Blakeley Formations of Kitsap Peninsula, Washington, M.S. thesis, Western Washington University, Bellingham, Washington, 138 pp., 1987.

Rau, W.W., Foraminifera from the northern Olympic Peninsula, Washington, U.S. Geol. Prof. Pap., 374G, G1-G33, 1964.

Roberts, T.H., Gravity investigation of crustal structure in the eastern Olympic Peninsula-Puget Lowland area, Washington, M.S. thesis, Western Washington University, Bellingham, Washington, 65 pp., 1991.

Schmidt, V.A., Circularity of paleomagnetic data sets: an aid in the recognition of contaminating secondary overprints, Tectonophysics, 184, 11-20, 1990.

Silberling, N.J., Jones, D.L., Blake, M.C., Jr., and Howell, D.G., Lithotectonic terrane maps of the North American Cordillera, in Lithotectonic Terrane Maps of the North America Cordillera, edited by N.J. Silberling and D.L. Jones, U.S. Geol. Surv. Prof. Pap., 1162-B, 28 pp., 1984.

Simpson, R.W. and Cox, A.V., Paleomagnetic evidence for the tectonic rotation of the Oregon Coast Range, Geology, 5, 585-589, 1977.

Snavely, P.D., Jr., Tertiary geologic framework, neotectonics, and petroleum potential of the Oregon-Washington continental margin, in Geology and Resource Potential of the Continental Margin of Western North America and Adjacent Ocean Basins - Beaufort Sea to Baja California, edited by D.W. Scholl, A. Grantz, and J.G. Vedder, Circum-Pacific Counc. Energy Min. Resour. Earth Sci. Ser., 6, 305-335, 1987.

Snavely, P.D., Jr., MacLeod, N.S., and Wagner, H.C., Tholeiitic and alkalic basalts of the Eocene Siletz River Volcanics, Oregon Coast Range, Am. J. Sci., 266, 454481, 1968.

Stock, J., and Molnar, P., Uncertainties and implications of the Late Cretaceous and Tertiary position of the North America relative to the Farallon, Kula, and Pacific plates, Tectonics, 7, 1339-1384, 1988.

Tabor, R.W. and Cady, W.M., Geologic map of the Olympic Peninsula, U.S. Geol. Surv. Map I-994, scale 1:250,000, 1978a. 
Tabor, R.W. and Cady, W.M., The structure of the Olympic Mountains, Washington analysis of a subduction zone, U.S. Geol. Surv. Prof. Pap., 1033, 38 pp., $1978 \mathrm{~b}$.

Warnock, A.C., Paleomagnetism of the Crescent Formation on the Olympic Peninsula, Washington: Senior thesis, Whitman College, Walla Walla, Washington, 29 pp., 1989.

Weaver, C.E., Tertiary Stratigraphy of Western Washington and Northwestern Oregon, University of Washington Press, Seattle, 266 pp., 1937.

Wells, R.E., Paleomagnetic rotations and the Cenozoic tectonics of the Cascade Arc, Washington, Oregon, and California, J. Geophys. Res., 95, 19409-19417, 1990.

Wells, R.E. and Coe, R.S., Paleomagnetism and geology of Eocene volcanic rocks of southwestern Washington, implications for mechanisms of tectonic rotations, $J$. Geophys. Res., 90, 1925-1947, 1985.

Wells, R.E., and Heller, P.L., The relative contribution of accretion, shear, and extension to Cenozoic tectonic rotation in the Pacific Northwest, Geol. Soc. Am. Bull., 100, 325-338, 1988.

Wells, R.E., Engebretson, D.C., Snavely, P.D., and Coe, R.S., Cenozoic plate motions and the volcano-tectonic evolution of western Oregon and Washington, Tectonics, 3, 275-294, 1984.

Wells, R.E., Kelly, M.M., Levi, S., Schultz, K., and McElwee, K., Folding and rotation of Paleocene pillow basalt near Roseburg, Oregon, (abstract), EOS Trans. AGU, 66, 863, 1985.

Zijderveld, J.D., A.C. demagnetization of rocks: Analysis of results, in Methods in Paleomagnetism, edited by D.W. Collinson, K.M. Creer, and S.K. Runcorn, Elsevier Science, New York, 254-286, 1967. 
APPENDIX: Sample Directions 
Notes: Dec and Inc: declination and inclination of sample directions; R: length of resultant vector; MAD: maximum angular deviation; Demag. Range: ${ }^{\circ} \mathrm{C}$ for thermal, $\mathrm{mT}$ for AF; Demag. Method: thermal ( $t$ ), alternating field (a), N: number of points used for line-fit; Line-Fit Type: (o) origin and (c) centroid are anchored and free-lines of Kirschvink [1980]; DipAz: azimuth of down-dip vector; Dip: angle of bedding tilt (angles greater than $90^{\circ}$ indicate overturned beds); ${ }^{*}: \gamma_{95}>15^{\circ} ; \dagger$ : sample was loose before orienting.

Site BQ01; N.Lat: 47.83, E.Lon: 236.98, DipAz: 120, Dip: 95

\begin{tabular}{|c|c|c|c|c|c|c|c|c|c|}
\hline \multirow[b]{2}{*}{ Sample } & \multirow[b]{2}{*}{ Dec } & \multirow[b]{2}{*}{ Inc } & \multirow[b]{2}{*}{$\mathbf{R}$} & \multirow[b]{2}{*}{ MAD } & \multicolumn{2}{|c|}{ Demag. Range } & \multicolumn{2}{|l|}{ Demag. } & \multirow{2}{*}{ Line-Fit } \\
\hline & & & & & Low & High & Method & $\mathbf{N}$ & \\
\hline 90BQ010101† & 181.4 & -25.2 & $3.289 \mathrm{E}-04$ & 6.1 & 450 & 560 & $t$ & 4 & 0 \\
\hline $90 \mathrm{BQ} 010101 \dagger$ & 185.0 & -25.0 & $1.510 \mathrm{E}-04$ & 12.7 & 450 & 560 & $t$ & 4 & c \\
\hline 90BQ010201 & 124.5 & -12.5 & $4.691 \mathrm{E}-04$ & 2.5 & 500 & 575 & $\mathrm{t}$ & 4 & 0 \\
\hline 90BQ010201 & 137.2 & $-7,1$ & $6.394 \mathrm{E}-05$ & 12.3 & 500 & 575 & $\mathrm{t}$ & 4 & c \\
\hline 90BQ010301 & 345.6 & +57.6 & $1.717 \mathrm{E}-03$ & 8.6 & 100 & 300 & $\mathbf{t}$ & 5 & o \\
\hline $90 \mathrm{BQ} 010301$ & 351.2 & +66.0 & $1.210 \mathrm{E}-03$ & 2.0 & 100 & 300 & $t$ & 5 & c \\
\hline 90BQ010401* & 146.3 & -20.9 & $5.578 \mathrm{E}-04$ & 2.3 & 450 & 575 & $t$ & 5 & 0 \\
\hline 90BQ010401* & 151.0 & -19.7 & $1.454 \mathrm{E}-04$ & 7.5 & 450 & 575 & $\mathrm{t}$ & 5 & c \\
\hline 90BQ010501* & 147.0 & -20.2 & $4.186 \mathrm{E}-03$ & 1.7 & 300 & 575 & $t$ & 6 & 0 \\
\hline 90BQ010501* & 148.7 & -19.3 & $1.666 \mathrm{E}-03$ & 3.9 & 300 & 575 & $t$ & 6 & c \\
\hline 90BQ010601 & 328.6 & +57.3 & $9.824 \mathrm{E}-05$ & 13.0 & 300 & 300 & $\mathrm{t}$ & 1 & 0 \\
\hline
\end{tabular}

Site EM01; N.Lat: 48.21, E.Lon: 235.67, DipAz: 22, Dip: 80

\begin{tabular}{lcrccccccc} 
Sample & \multicolumn{1}{c}{ Dec } & \multicolumn{1}{c}{ Inc } & R & MAD & Low & Low. Range & Demag. & & Line-Fit \\
Method & N & Type \\
\hline 90EM010101 & 44.6 & +26.2 & $1.534 \mathrm{E}-03$ & 1.8 & 300 & 560 & $\mathrm{t}$ & 5 & $\mathrm{o}$ \\
90EM010101 & 45.3 & +28.3 & $7.161 \mathrm{E}-04$ & 2.9 & 300 & 560 & $\mathrm{t}$ & 5 & $\mathrm{c}$ \\
90EM010201 & 61.2 & +25.4 & $2.507 \mathrm{E}-03$ & 1.9 & 350 & 560 & $\mathrm{t}$ & 6 & $\mathrm{o}$ \\
90EM010201 & 59.5 & +26.3 & $1.097 \mathrm{E}-03$ & 3.9 & 350 & 560 & $\mathrm{t}$ & 6 & $\mathrm{c}$ \\
90EM010301* & 19.1 & -68.5 & $6.150 \mathrm{E}-04$ & 2.7 & 300 & 560 & $\mathrm{t}$ & 5 & $\mathrm{o}$ \\
90EM010301* & 23.9 & -70.2 & $2.663 \mathrm{E}-04$ & 5.6 & 300 & 560 & $\mathrm{t}$ & 5 & $\mathrm{c}$ \\
90EM010401† & 35.5 & -2.5 & $4.486 \mathrm{E}-03$ & 0.8 & 300 & 575 & $\mathrm{t}$ & 6 & $\mathrm{o}$ \\
90EM010401† & 35.3 & -2.2 & $2.645 \mathrm{E}-03$ & 1.2 & 300 & 575 & $\mathrm{t}$ & 6 & $\mathrm{c}$ \\
90EM010501 & 53.3 & +22.0 & $1.829 \mathrm{E}-03$ & 2.4 & 300 & 560 & $\mathrm{t}$ & 5 & $\mathrm{o}$ \\
90EM010501 & 52.6 & +23.3 & $9.285 \mathrm{E}-04$ & 4.3 & 300 & 560 & $\mathrm{t}$ & 5 & $\mathrm{c}$ \\
90EM010601 & 67.1 & +32.4 & $2.933 \mathrm{E}-03$ & 3.2 & 300 & 560 & $\mathrm{t}$ & 5 & $\mathrm{o}$ \\
90EM010601 & 67.5 & +32.5 & $1.887 \mathrm{E}-03$ & 4.9 & 300 & 560 & $\mathrm{t}$ & 5 & $\mathrm{c}$ \\
90EM010701 & 62.7 & +41.1 & $1.077 \mathrm{E}-03$ & 1.5 & 450 & 560 & $\mathrm{t}$ & 4 & $\mathrm{o}$ \\
90EM010701 & 63.2 & +43.2 & $5.547 \mathrm{E}-04$ & 1.6 & 450 & 560 & $\mathrm{t}$ & 4 & $\mathrm{c}$ \\
90EM010801 & 235.2 & +3.0 & $2.698 \mathrm{E}-03$ & 1.7 & 300 & 560 & $\mathrm{t}$ & $\mathbf{5}$ & $\mathrm{o}$ \\
90EM010801 & 234.6 & +4.4 & $1.418 \mathrm{E}-03$ & 2.6 & 300 & 560 & $\mathrm{t}$ & 5 & $\mathrm{c}$ \\
90EM010901 & 224.5 & +9.6 & $4.481 \mathrm{E}-03$ & 1.5 & 300 & 560 & $\mathrm{t}$ & 5 & $\mathrm{o}$ \\
90EM010901 & 223.5 & +10.6 & $2.572 \mathrm{E}-03$ & 2.0 & 300 & 560 & $\mathrm{t}$ & 5 & $\mathrm{c}$ \\
90EM011001 & 221.6 & -2.0 & $8.426 \mathrm{E}-04$ & 0.9 & 450 & 560 & $\mathrm{t}$ & 4 & $\mathrm{o}$ \\
90EM011001 & 221.7 & -1.7 & $4.457 \mathrm{E}-04$ & 1.7 & 450 & 560 & $\mathrm{t}$ & 4 & $\mathrm{c}$
\end{tabular}


Locality ER; N.Lat: 48.04, E.Lon: 236.41, DipAz: 10, Dip: 90

\begin{tabular}{|c|c|c|c|c|c|c|c|c|c|}
\hline & & & & & Demą & & & & Line-Fit \\
\hline Sample & Dec & Inc & $\mathbf{R}$ & MAD & Low & High & Method & $\mathrm{N}$ & Type \\
\hline 90ER010201 & 80.1 & -1.2 & $6.096 \mathrm{E}-03$ & 3.3 & 300 & 560 & $t$ & 5 & 0 \\
\hline 90ER010201 & 67.7 & +20.6 & $4.358 \mathrm{E}-04$ & 35.6 & 300 & 560 & $t$ & 5 & c \\
\hline 90ER010401 & 113.0 & +26.7 & $2.723 \mathrm{E}-03$ & 1.1 & 450 & 560 & $t$ & 4 & 0 \\
\hline 90ER010401 & 115.7 & +39.6 & $1.904 \mathrm{E}-04$ & 8.5 & 450 & 560 & t & 4 & c \\
\hline 90ER010501 & 74.2 & +7.9 & $1.211 \mathrm{E}-02$ & 1.5 & 300 & 585 & $t$ & 7 & o \\
\hline 90ER010501 & 74.6 & +10.2 & $2.384 \mathrm{E}-03$ & 7.1 & 300 & 585 & $\mathbf{t}$ & 7 & c \\
\hline 90ER010601 & 84.4 & +10.1 & $9.578 \mathrm{E}-03$ & 3.1 & 300 & 585 & t & 7 & 0 \\
\hline 90ER010601 & 85.5 & +12.1 & 2.673E-03 & 10.7 & 300 & 585 & $\mathrm{t}$ & 7 & c \\
\hline 90ER010701 & 70.9 & +5.2 & $7.547 \mathrm{E}-03$ & 1.5 & 500 & 580 & $\mathrm{t}$ & 5 & 0 \\
\hline 90ER010701 & 72.6 & +4.9 & $3.577 \mathrm{E}-03$ & 2.4 & 500 & 580 & $t$ & 5 & c \\
\hline 90ER020101 & 44.5 & -10.4 & 4.335E-03 & 1.8 & 450 & 585 & $\mathrm{t}$ & 6 & o \\
\hline 90ER020101 & 46.1 & -9.9 & $1.580 \mathrm{E}-03$ & 4.6 & 450 & 585 & $t$ & 6 & c \\
\hline 90ER020201 & 32.8 & -16.9 & $2.201 \mathrm{E}-03$ & 1.9 & 450 & 575 & t & 5 & 0 \\
\hline 90ER020201 & 30.4 & -15.1 & $3.411 \mathrm{E}-04$ & 11.9 & 450 & 575 & $t$ & 5 & c \\
\hline 90ER020301 & 14.8 & -1.4 & $1.481 \mathrm{E}-04$ & 4.5 & 500 & 575 & $\mathrm{t}$ & 4 & 0 \\
\hline 90ER020301 & 20.1 & +8.3 & 4.323E-05 & 10.2 & 500 & 575 & $\mathrm{t}$ & 4 & c \\
\hline 90ER020401 & 15.7 & +17.0 & $5.396 \mathrm{E}-03$ & 2.7 & 250 & 580 & $t$ & 10 & o \\
\hline 90ER020401 & 16.8 & +17.6 & $1.712 \mathrm{E}-03$ & 8.2 & 250 & 580 & $\mathrm{t}$ & 10 & c \\
\hline 90ER020501 & 8.9 & +13.4 & $6.443 \mathrm{E}-03$ & 2.8 & 300 & 575 & $t$ & 6 & 0 \\
\hline 90ER020501 & 8.1 & +13.6 & $1.799 \mathrm{E}-03$ & 9.9 & 300 & 575 & $t$ & 6 & c \\
\hline 90ER020601 & 13.4 & +7.9 & $3.463 \mathrm{E}-03$ & 1.7 & 300 & 575 & $t$ & 6 & 0 \\
\hline 90ER020601 & 11.6 & +10.3 & $9.550 \mathrm{E}-04$ & 5.2 & 300 & 575 & $t$ & 6 & c \\
\hline 90ER020701† & 37.7 & +14.9 & $8.590 \mathrm{E}-04$ & 5.4 & 300 & 560 & $t$ & 5 & 0 \\
\hline 90ER020701† & 30.2 & +40.4 & $1.481 \mathrm{E}-04$ & 19.7 & 300 & 560 & $\mathrm{t}$ & 5 & c \\
\hline 90ER030101 & 10.3 & +47.1 & $1.934 \mathrm{E}-02$ & 1.5 & 300 & 575 & $t$ & 6 & 0 \\
\hline 90ER030101 & 9.7 & +46.4 & 8.192E-03 & 3.4 & 300 & 575 & $t$ & 6 & c \\
\hline 90ER030301 & 17.5 & +40.9 & $7.194 \mathrm{E}-03$ & 2.1 & 300 & 560 & $\mathrm{t}$ & 5 & 0 \\
\hline 90ER030301 & 17.9 & +42.6 & $2.211 \mathrm{E}-03$ & 6.5 & 300 & 560 & $\mathrm{t}$ & 5 & c \\
\hline 90ER030401 & 24.6 & +16.9 & $3.270 \mathrm{E}-02$ & 1.5 & 300 & 575 & $t$ & 6 & 0 \\
\hline 90ER030401 & 24.5 & +17.4 & $1.310 \mathrm{E}-02$ & 3.7 & 300 & 575 & $\mathrm{t}$ & 6 & c \\
\hline 90ER030501 & 9.9 & +49.6 & $4.400 \mathrm{E}-03$ & 1.7 & 300 & 560 & $\mathrm{t}$ & 5 & o \\
\hline 90ER030501 & 10.9 & +55.3 & $6.670 \mathrm{E}-04$ & 9.7 & 300 & 560 & t & 5 & c \\
\hline 90ER030601* & 17.0 & +34.8 & $7.210 \mathrm{E}-03$ & 1.7 & 300 & 560 & $\mathrm{t}$ & 7 & 0 \\
\hline 90ER030601* & 15.3 & +36.9 & $7.720 \mathrm{E}-04$ & 15.5 & 300 & 560 & $\mathrm{t}$ & 7 & c \\
\hline 90ER040101 & 16.4 & +45.3 & $1.552 \mathrm{E}-02$ & 1.2 & 300 & 575 & $t$ & 6 & 0 \\
\hline 90ER040101 & 16.7 & +45.1 & $5.555 \mathrm{E}-03$ & 3.3 & 300 & 575 & t & 6 & c \\
\hline 90ER040201 & 45.8 & +30.6 & $1.160 \mathrm{E}-02$ & 1.0 & 300 & 575 & $t$ & 8 & o \\
\hline 90ER040201 & 47.0 & +31.5 & $2.845 \mathrm{E}-03$ & 4.0 & 300 & 575 & $t$ & 8 & c \\
\hline 90ER040301 & 38.6 & +46.2 & $1.729 \mathrm{E}-02$ & 1.1 & 300 & 575 & $t$ & 6 & 0 \\
\hline 90ER040301 & 38.2 & +46.6 & $6.936 \mathrm{E}-03$ & 2.7 & 300 & 575 & $t$ & 6 & c \\
\hline 90ER040401 & 38.1 & +31.4 & $1.328 \mathrm{E}-03$ & 2.3 & 300 & 560 & $t$ & 5 & 0 \\
\hline 90ER040401 & 51.5 & +36.3 & $1.541 \mathrm{E}-04$ & 15.0 & 300 & 560 & $\mathrm{t}$ & 5 & c \\
\hline 90ER040501 & 74.3 & +59.0 & $3.950 \mathrm{E}-04$ & 1.8 & 450 & 560 & $t$ & 4 & 0 \\
\hline 90ER040501 & 53.5 & +52.2 & $4.042 \mathrm{E}-05$ & 11.9 & 450 & 560 & $t$ & 4 & c \\
\hline
\end{tabular}


Site HR01; N.Lat: 47.99, E.Lon: 236.62, DipAz: 346, Dip: 69

\begin{tabular}{|c|c|c|c|c|c|c|c|c|c|}
\hline \multirow[b]{2}{*}{ Sample } & \multirow[b]{2}{*}{ Dec } & \multirow[b]{2}{*}{ Inc } & \multirow[b]{2}{*}{$\mathbf{R}$} & \multirow[b]{2}{*}{ MAD } & \multicolumn{2}{|c|}{ Demag. Range } & \multirow{2}{*}{$\begin{array}{l}\text { Demag. } \\
\text { Method }\end{array}$} & \multicolumn{2}{|r|}{ Line-Fit } \\
\hline & & & & & Low & High & & $\mathbf{N}$ & Type \\
\hline 89HR010101* & 172.2 & +29.6 & $1.198 \mathrm{E}-04$ & 2.8 & 450 & 575 & $t$ & 7 & 0 \\
\hline 89HR010101* & 177.0 & +30.7 & $4.955 \mathrm{E}-05$ & 4.9 & 450 & 575 & $t$ & 7 & c \\
\hline 89HR010201† & 27.4 & +45.1 & $2.057 \mathrm{E}-05$ & 8.0 & 450 & 575 & $t$ & 7 & 0 \\
\hline $89 \mathrm{HR} 010201 \dagger$ & 11.4 & +55.7 & 7.403E-06 & 15.9 & 450 & 575 & 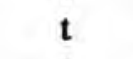 & 7 & c \\
\hline 89 HR010301† & 166.3 & +42.9 & $3.008 \mathrm{E}-05$ & 8.9 & 450 & 570 & $t$ & 6 & o \\
\hline 89HR010301† & 166.2 & +49.0 & $1.464 \mathrm{E}-05$ & 16.6 & 450 & 570 & $t$ & 6 & c \\
\hline 89HR010401† & 145.4 & +50.8 & $2.794 \mathrm{E}-04$ & 2.5 & 450 & 570 & $t$ & 6 & o \\
\hline 89HR010401† & 143.5 & +53.9 & $1.087 \mathrm{E}-04$ & 5.4 & 450 & 570 & $\mathrm{t}$ & 6 & c \\
\hline $89 \mathrm{HR} 010501 \dagger$ & 185.2 & +36.2 & $5.094 \mathrm{E}-05$ & 3.6 & 450 & 560 & $t$ & 5 & 0 \\
\hline $89 \mathrm{HR} 010501 \dagger$ & 185.8 & +35.5 & $2.808 \mathrm{E}-05$ & 6.4 & 450 & 560 & $t$ & 5 & c \\
\hline 90HR010602 & 151.6 & +34.1 & $3.415 \mathrm{E}-04$ & 3.4 & 300 & 540 & $\mathbf{t}$ & 4 & o \\
\hline 90HR010602 & 151.6 & +35.9 & $1.642 \mathrm{E}-04$ & 6.8 & 300 & 540 & $t$ & 4 & c \\
\hline 90HR010701 & 164.8 & +28.5 & $1.101 \mathrm{E}-03$ & 3.2 & 300 & 540 & $\mathrm{t}$ & 4 & 0 \\
\hline 90HR010701 & 150.9 & +42.8 & $1.903 \mathrm{E}-04$ & 3.6 & 300 & 540 & $t$ & 4 & c \\
\hline 90HR010801 & 152.8 & +35.3 & $1.324 \mathrm{E}-04$ & 1.6 & 475 & 560 & $t$ & 4 & o \\
\hline 90HR010801 & 153.6 & +37.7 & $4.807 \mathrm{E}-05$ & 3.4 & 475 & 560 & $t$ & 4 & c \\
\hline
\end{tabular}

Site HR02; N.Lat: 47.99, E.Lon: 236.62, DipAz: 355, Dip: 64

\begin{tabular}{lccccccccc}
\multicolumn{1}{c}{ Sample } & Dec & Inc & R & MAD & Lemag. Range & Demag. & \multicolumn{2}{c}{ Line-Fit } \\
\hline 90HR020101 $\dagger$ & 191.9 & +61.7 & $2.870 \mathrm{E}-04$ & 13.9 & 300 & 540 & $\mathrm{t}$ & 7 & $\mathrm{o}$ \\
90HR020101 $\dagger$ & 212.9 & +79.3 & $1.704 \mathrm{E}-04$ & 10.1 & 300 & 540 & $\mathrm{t}$ & 7 & $\mathrm{c}$ \\
90HR020202 & 188.7 & +35.3 & $3.646 \mathrm{E}-04$ & 2.4 & 450 & 560 & $\mathrm{t}$ & 4 & $\mathrm{o}$ \\
90HR020202 & 184.0 & +37.5 & $1.254 \mathrm{E}-04$ & 5.2 & 450 & 560 & $\mathrm{t}$ & 4 & $\mathrm{c}$ \\
90HR020301 & 178.0 & +43.0 & $7.717 \mathrm{E}-04$ & 4.0 & 450 & 560 & $\mathrm{t}$ & 4 & $\mathrm{o}$ \\
90HR020301 & 156.3 & +61.4 & $1.240 \mathrm{E}-04$ & 12.1 & 450 & 560 & $\mathrm{t}$ & 4 & $\mathrm{c}$ \\
90HR020401 & 165.9 & +49.5 & $1.906 \mathrm{E}-04$ & 2.7 & 475 & 560 & $\mathrm{t}$ & 4 & $\mathrm{o}$ \\
90HR020401 & 161.6 & +53.5 & $6.945 \mathrm{E}-05$ & 5.2 & 475 & 560 & $\mathrm{t}$ & 4 & $\mathrm{c}$ \\
90HR020501 & 174.5 & +59.3 & $2.679 \mathrm{E}-04$ & 2.0 & 450 & 560 & $\mathrm{t}$ & 4 & $\mathrm{o}$ \\
90HR020501 & 181.9 & +59.3 & $4.796 \mathrm{E}-05$ & 10.1 & 450 & 560 & $\mathrm{t}$ & 4 & $\mathrm{c}$ \\
90HR020602 & 177.2 & +39.1 & $1.513 \mathrm{E}-03$ & 1.4 & 450 & 560 & $\mathrm{t}$ & 4 & $\mathrm{o}$ \\
90HR020602 & 179.5 & +43.8 & $3.039 \mathrm{E}-04$ & 4.9 & 450 & 560 & $\mathrm{t}$ & 4 & $\mathrm{c}$ \\
90HR020701* & 316.5 & +75.2 & $2.806 \mathrm{E}-04$ & 3.2 & 300 & 560 & $\mathrm{t}$ & 5 & $\mathrm{o}$ \\
90HR020701* & 312.9 & +72.7 & $1.373 \mathrm{E}-04$ & 5.7 & 300 & 560 & $\mathrm{t}$ & 5 & $\mathrm{c}$
\end{tabular}


Site HR03; N.Lat: 47.99, E.Lon: 236.62, DipAz: 359, Dip: 69

\begin{tabular}{lrcccccccc}
\multicolumn{1}{c}{ Sample } & \multicolumn{1}{c}{ Dec } & \multicolumn{1}{c}{ Inc } & R & MAD & Lemag. Range & Demag. & \multicolumn{2}{c}{ Line-Fit } \\
90HR030101 & 16.8 & +71.0 & $5.618 \mathrm{E}-04$ & 2.1 & 15 & 65 & $\mathrm{a}$ & 8 & $\mathrm{o}$ \\
90HR030101 & 11.8 & +68.2 & $2.023 \mathrm{E}-04$ & 4.5 & 15 & 65 & $\mathrm{a}$ & 8 & $\mathrm{c}$ \\
90HR030201 & 14.8 & +68.4 & $6.315 \mathrm{E}-04$ & 1.9 & 10 & 40 & $\mathrm{a}$ & 4 & $\mathrm{o}$ \\
90HR030201 & 8.9 & +68.5 & $3.070 \mathrm{E}-04$ & 3.0 & 10 & 40 & $\mathrm{a}$ & 4 & $\mathrm{c}$ \\
90HR030301 & 28.4 & +67.9 & $2.960 \mathrm{E}-03$ & 2.3 & 20 & 90 & $\mathrm{a}$ & 8 & $\mathrm{o}$ \\
90HR030301 & 29.6 & +68.7 & $1.749 \mathrm{E}-03$ & 3.7 & 20 & 90 & $\mathrm{a}$ & 8 & $\mathrm{c}$ \\
90HR030401* & 21.8 & +75.7 & $7.493 \mathrm{E}-05$ & 6.7 & 350 & 560 & $\mathrm{t}$ & 6 & $\mathrm{o}$ \\
90HR030401* & 31.8 & +82.5 & $3.982 \mathrm{E}-05$ & 9.5 & 350 & 560 & $\mathrm{t}$ & 6 & $\mathrm{c}$ \\
90HR030502* & 115.0 & +74.6 & $5.482 \mathrm{E}-05$ & 1.6 & 450 & 540 & $\mathrm{t}$ & 3 & $\mathrm{o}$ \\
90HR030502* & 108.6 & +70.1 & $9.667 \mathrm{E}-06$ & 7.3 & 450 & 540 & $\mathrm{t}$ & 3 & $\mathrm{c}$ \\
90HR030601 & 162.8 & +68.4 & $1.573 \mathrm{E}-04$ & 6.9 & 300 & 540 & $\mathrm{t}$ & 4 & $\mathrm{o}$ \\
90HR030601 & 156.0 & +82.2 & $6.842 \mathrm{E}-05$ & 4.9 & 300 & 540 & $\mathrm{t}$ & 4 & $\mathrm{c}$ \\
90HR030703 & 26.4 & +77.9 & $1.134 \mathrm{E}-03$ & 2.6 & 300 & 575 & $\mathrm{t}$ & 6 & $\mathrm{o}$ \\
90HR030703 & 18.8 & +76.5 & $7.401 \mathrm{E}-04$ & 2.7 & 300 & 575 & $\mathrm{t}$ & 6 & $\mathrm{c}$
\end{tabular}

Site HR04; N.Lat: 47.99, E.Lon: 236.62, DipAz: 5, Dip: 80

\begin{tabular}{|c|c|c|c|c|c|c|c|c|c|}
\hline \multirow[b]{2}{*}{ Sample } & \multirow[b]{2}{*}{ Dec } & \multirow[b]{2}{*}{ Inc } & \multirow[b]{2}{*}{$\mathbf{R}$} & \multirow[b]{2}{*}{ MAD } & \multicolumn{2}{|c|}{ Demag. Range } & \multirow{2}{*}{$\begin{array}{l}\text { Demag. } \\
\text { Method }\end{array}$} & \multirow[b]{2}{*}{$\mathrm{N}$} & \multirow{2}{*}{$\begin{array}{c}\text { Line-Fit } \\
\text { Type }\end{array}$} \\
\hline & & & & & Low & High & & & \\
\hline 90HR040101 & 180.9 & +50.2 & $3.390 \mathrm{E}-04$ & 2.6 & 20 & 45 & $a$ & 6 & 0 \\
\hline 90HR040101 & 184.1 & +50.1 & $1.373 \mathrm{E}-04$ & 6.0 & 20 & 45 & a & 6 & c \\
\hline $90 \mathrm{HR} 040201 \dagger$ & 23.4 & +65.7 & $1.410 \mathrm{E}-04$ & 3.5 & 350 & 560 & $\mathrm{t}$ & 6 & 0 \\
\hline $90 \mathrm{HR} 040201 \dagger$ & 17.3 & +66.3 & $6.933 \mathrm{E}-05$ & 6.4 & 350 & 560 & $t$ & 6 & c \\
\hline 90HR040301 & 166.1 & +48.8 & $2.075 \mathrm{E}-04$ & 2.8 & 20 & 50 & a & 4 & o \\
\hline 90HR040301 & 168.5 & +45.4 & $1.208 \mathrm{E}-04$ & 1.3 & 20 & 50 & a & 4 & c \\
\hline 90HR040401 & 171.4 & +47.4 & $1.008 \mathrm{E}-04$ & 3.3 & 450 & 560 & $\mathrm{t}$ & 4 & 0 \\
\hline $90 \mathrm{HR} 040401$ & 176.2 & +53.7 & $3.447 \mathrm{E}-05$ & 6.0 & 450 & 560 & $t$ & 4 & c \\
\hline 90HR040501† & 249.3 & +74.7 & $2.432 \mathrm{E}-04$ & 3.2 & 20 & 60 & a & 5 & o \\
\hline 90HR040501† & 264.5 & +77.7 & $1.111 \mathrm{E}-04$ & 4.7 & 20 & 60 & a & 5 & c \\
\hline 90HR040601 & 162.6 & +44.5 & $1.970 \mathrm{E}-04$ & 3.3 & 300 & 540 & $\mathrm{t}$ & 4 & 0 \\
\hline 90HR040601 & 148.6 & +44.2 & $5.082 \mathrm{E}-05$ & 8.0 & 300 & 540 & $\mathrm{t}$ & 4 & c \\
\hline
\end{tabular}


Site HR05; N.Lat: 47.99, E.Lon: 236.63, DipAz: 25, Dip: 60

\begin{tabular}{|c|c|c|c|c|c|c|c|c|c|}
\hline \multirow[b]{2}{*}{ Sample } & \multirow[b]{2}{*}{ Dec } & \multirow[b]{2}{*}{ Inc } & \multirow[b]{2}{*}{$\mathbf{R}$} & \multirow[b]{2}{*}{ MAD } & \multicolumn{2}{|c|}{ Demag. Range } & \multirow{2}{*}{$\begin{array}{l}\text { Demag. } \\
\text { Method }\end{array}$} & \multirow[b]{2}{*}{$\mathrm{N}$} & \multirow{2}{*}{$\begin{array}{c}\text { Line-Fit } \\
\text { Type }\end{array}$} \\
\hline & & & & & Low & High & & & \\
\hline 90HR050101 & 254.0 & +29.4 & $3.170 \mathrm{E}-04$ & 1.5 & 450 & 560 & $t$ & 4 & 0 \\
\hline 90HR050101 & 255.5 & +27.5 & $1.437 \mathrm{E}-04$ & 2.1 & 450 & 560 & $t$ & 4 & c \\
\hline 90HR050201* & 330.4 & +65.6 & $6.126 \mathrm{E}-04$ & 3.9 & 20 & 60 & a & 8 & 0 \\
\hline 90HR050201* & 350.2 & +59.0 & $1.873 \mathrm{E}-04$ & 4.7 & 20 & 60 & a & 8 & c \\
\hline 90HR050301 & 238.5 & +38.0 & $6.907 \mathrm{E}-04$ & 3.6 & 350 & 560 & $t$ & 6 & 0 \\
\hline 90HR050301 & 239.7 & +42.6 & $2.704 \mathrm{E}-04$ & 7.7 & 350 & 560 & $t$ & 6 & c \\
\hline 90HR050401* & 236.7 & +35.3 & 5.582E-05 & 4.8 & 450 & 560 & $t$ & 4 & 0 \\
\hline 90HR050401* & 237.3 & +43.7 & $1.994 \mathrm{E}-05$ & 9.9 & 450 & 560 & $\mathrm{t}$ & 4 & c \\
\hline 90HR050501* & 251.2 & +8.4 & $2.080 \mathrm{E}-04$ & 4.5 & 450 & 560 & $t$ & 4 & 0 \\
\hline 90HR050501* & 254.6 & +18.2 & $4.722 \mathrm{E}-05$ & 16.8 & 450 & 560 & $t$ & 4 & c \\
\hline 90HR050601 & 234.0 & +26.1 & $3.698 \mathrm{E}-04$ & 2.5 & 450 & 560 & $\mathrm{t}$ & 4 & o \\
\hline 90HR050601 & 240.3 & +33.2 & $4.407 \mathrm{E}-05$ & 18.7 & 450 & 560 & $t$ & 4 & c \\
\hline 90HR050701 & 243.5 & +20.7 & $2.623 \mathrm{E}-04$ & 1.6 & 450 & 575 & $t$ & 5 & o \\
\hline 90HR050701 & 246.9 & +21.0 & $8.598 \mathrm{E}-05$ & 3.7 & 450 & 575 & $t$ & 5 & c \\
\hline
\end{tabular}

Site LC01; N.Lat: 48.07, E.Lon: 236.21, DipAz: 356, Dip: 66

\begin{tabular}{lrrrrrrrrc}
\multicolumn{1}{c}{ Sample } & Dec & Inc & R & MAD & Low & High & $\begin{array}{c}\text { Demag. } \\
\text { Method }\end{array}$ & N & $\begin{array}{c}\text { Line-Fit } \\
\text { Type }\end{array}$ \\
\hline 90LC010101 & 181.7 & +19.4 & $1.623 \mathrm{E}-02$ & 1.7 & 300 & 560 & $\mathrm{t}$ & 5 & $\mathrm{o}$ \\
90LC010101 & 181.2 & +19.3 & $7.810 \mathrm{E}-03$ & 3.6 & 300 & 560 & $\mathrm{t}$ & 5 & $\mathrm{c}$ \\
90LC010201 & 189.5 & +86.2 & $3.279 \mathrm{E}-03$ & 2.8 & 10 & 50 & $\mathrm{a}$ & 8 & $\mathrm{o}$ \\
90LC010201 & 181.9 & +85.1 & $2.068 \mathrm{E}-03$ & 4.1 & 10 & 50 & $\mathrm{a}$ & 8 & $\mathrm{c}$ \\
90LC010302* & 74.6 & -64.7 & $3.016 \mathrm{E}-02$ & 0.9 & 300 & 575 & $\mathrm{t}$ & 6 & $\mathrm{o}$ \\
90LC010302* & 256.1 & +65.2 & $1.841 \mathrm{E}-02$ & 1.0 & 300 & 575 & $\mathrm{t}$ & 6 & $\mathrm{c}$ \\
90LC010401 & 138.5 & +61.8 & $1.251 \mathrm{E}-03$ & 2.4 & 10 & 25 & $\mathrm{a}$ & 4 & $\mathrm{o}$ \\
90LC010401 & 144.3 & +60.3 & $5.360 \mathrm{E}-04$ & 4.2 & 10 & 25 & $\mathrm{a}$ & 4 & $\mathrm{c}$ \\
90LC010501 & 187.3 & +50.5 & $1.026 \mathrm{E}-01$ & 0.8 & 250 & 560 & $\mathrm{t}$ & 8 & $\mathrm{o}$ \\
90LC010501 & 187.0 & +50.4 & $5.208 \mathrm{E}-02$ & 1.5 & 250 & 560 & $\mathrm{t}$ & 8 & $\mathrm{c}$
\end{tabular}


Site LC02; N.Lat: 48.07, ELon: 236.22, DipAz: 8, Dip: 80

\begin{tabular}{lccccccccc}
\multicolumn{1}{c}{ Sample } & Dec & Inc & R & MAD & Low & High & $\begin{array}{c}\text { Demag. } \\
\text { Method }\end{array}$ & N & $\begin{array}{c}\text { Line-Fit } \\
\text { Type }\end{array}$ \\
\hline 90LC020101 & 181.3 & +49.9 & $1.465 \mathrm{E}-03$ & 3.1 & 450 & 540 & $\mathrm{t}$ & 3 & $\mathrm{o}$ \\
90LC020101 & 171.2 & +53.3 & $4.812 \mathrm{E}-04$ & 5.7 & 450 & 540 & $\mathrm{t}$ & 3 & $\mathrm{c}$ \\
90LC020301† & 228.7 & +55.5 & $1.352 \mathrm{E}-03$ & 9.4 & 300 & 540 & $\mathrm{t}$ & 4 & $\mathrm{o}$ \\
90LC020301† & 224.2 & +65.5 & $6.294 \mathrm{E}-04$ & 16.4 & 300 & 540 & $\mathrm{t}$ & 4 & $\mathrm{c}$ \\
90LC020401 & 204.5 & +39.8 & $1.439 \mathrm{E}-03$ & 5.0 & 300 & 540 & $\mathrm{t}$ & 4 & $\mathrm{o}$ \\
90LC020401 & 208.1 & +37.8 & $6.657 \mathrm{E}-04$ & 10.0 & 300 & 540 & $\mathrm{t}$ & 4 & $\mathrm{c}$ \\
90LC020501* & 147.9 & -32.5 & $2.656 \mathrm{E}-03$ & 5.0 & 450 & 560 & $\mathrm{t}$ & 4 & $\mathrm{o}$ \\
90LC020501* & 152.9 & -36.4 & $1.556 \mathrm{E}-03$ & 5.1 & 450 & 560 & $\mathrm{t}$ & 4 & $\mathrm{c}$ \\
90LC020601 & 234.3 & +13.4 & $2.267 \mathrm{E}-03$ & 4.5 & 300 & 500 & $\mathrm{t}$ & 3 & $\mathrm{o}$ \\
90LC020601 & 236.8 & +27.2 & $6.313 \mathrm{E}-04$ & 7.1 & 300 & 500 & $\mathrm{t}$ & 3 & $\mathrm{c}$ \\
90LC020701 & 213.9 & +25.6 & $3.460 \mathrm{E}-03$ & 4.9 & 300 & 540 & $\mathrm{t}$ & 4 & $\mathrm{o}$ \\
90LC020701 & 213.7 & +29.0 & $1.465 \mathrm{E}-03$ & 10.8 & 300 & 540 & $\mathrm{t}$ & 4 & $\mathrm{c}$ \\
90LC020801 & 193.6 & +29.1 & $1.366 \mathrm{E}-03$ & 1.5 & 450 & 560 & $\mathrm{t}$ & 4 & $\mathrm{o}$ \\
90LC020801 & 193.1 & +30.4 & $9.063 \mathrm{E}-04$ & 1.3 & 450 & 560 & $\mathrm{t}$ & 4 & $\mathrm{c}$ \\
90LC020901 & 205.5 & +43.0 & $1.503 \mathrm{E}-03$ & 3.6 & 300 & 540 & $\mathrm{t}$ & 4 & $\mathrm{o}$ \\
90LC020901 & 208.1 & +46.8 & $6.484 \mathrm{E}-04$ & 6.9 & 300 & 540 & $\mathrm{t}$ & 4 & $\mathrm{c}$ \\
90LC021001 & 201.8 & +39.4 & $4.329 \mathrm{E}-03$ & 2.5 & 300 & 500 & $\mathrm{t}$ & 3 & $\mathrm{o}$ \\
90LC021001 & 199.0 & +43.7 & $1.733 \mathrm{E}-03$ & 3.3 & 300 & 500 & $\mathrm{t}$ & 3 & $\mathrm{c}$ \\
90LC021101 & 181.6 & +18.3 & $4.885 \mathrm{E}-03$ & 2.4 & 300 & 540 & $\mathrm{t}$ & 4 & $\mathrm{o}$ \\
90LC021101 & 181.2 & +19.7 & $2.131 \mathrm{E}-03$ & 5.3 & 300 & 540 & $\mathrm{t}$ & 4 & $\mathrm{c}$ \\
90LC021201 & 212.4 & +31.6 & $8.221 \mathrm{E}-03$ & 1.5 & 300 & 540 & $\mathrm{t}$ & 4 & $\mathrm{o}$ \\
90LC021201 & 211.0 & +31.1 & $3.699 \mathrm{E}-03$ & 3.0 & 300 & 540 & $\mathrm{t}$ & 4 & $\mathrm{c}$ \\
90LC021301 & 208.3 & +32.2 & $1.854 \mathrm{E}-03$ & 1.4 & 450 & 575 & $\mathrm{t}$ & 5 & $\mathrm{o}$ \\
90LC021301 & 210.2 & +31.8 & $8.881 \mathrm{E}-04$ & 2.4 & 450 & 575 & $\mathrm{t}$ & 5 & $\mathrm{c}$ \\
90LC021401 & 181.7 & +41.9 & $6.574 \mathrm{E}-03$ & 2.7 & 300 & 500 & $\mathrm{t}$ & 5 & $\mathrm{o}$ \\
90LC021401 & 163.1 & +40.6 & $1.009 \mathrm{E}-03$ & 10.2 & 300 & 500 & $\mathrm{t}$ & 5 & $\mathrm{c}$
\end{tabular}

Site LC03; N.Lat: 48.07, E.Lon: 236.22, DipAz: 10, Dip: 85

\begin{tabular}{lrrrrrrrrc}
\multicolumn{1}{c}{ Sample } & Dec & Inc & R & MAD & Low & High & Method & N & $\begin{array}{c}\text { Line-Fit } \\
\text { Type }\end{array}$ \\
\hline 90LC030101 & 272.8 & +22.0 & $1.292 \mathrm{E}-03$ & 9.5 & 300 & 540 & $\mathrm{t}$ & 6 & $\mathrm{o}$ \\
90LC030101 & 275.2 & +12.4 & $6.146 \mathrm{E}-04$ & 16.7 & 300 & 540 & $\mathrm{t}$ & 6 & $\mathrm{c}$ \\
90LC030301* & 305.0 & +74.2 & $2.222 \mathrm{E}-04$ & 24.6 & 300 & 500 & $\mathrm{t}$ & 3 & $\mathrm{o}$ \\
90LC030301* & 356.1 & +40.0 & $1.356 \mathrm{E}-04$ & 4.7 & 300 & 500 & $\mathrm{t}$ & 3 & $\mathrm{c}$ \\
90LC030401* & 18.3 & +69.5 & $3.263 \mathrm{E}-04$ & 9.2 & 300 & 500 & $\mathrm{t}$ & 3 & $\mathrm{o}$ \\
90LC030401* & 66.6 & +51.9 & $9.431 \mathrm{E}-05$ & 17.0 & 300 & 500 & $\mathrm{t}$ & 3 & $\mathrm{c}$ \\
90LC030501* & 24.1 & +75.8 & $2.873 \mathrm{E}-04$ & 1.5 & 300 & 500 & $\mathrm{t}$ & 3 & $\mathrm{o}$ \\
90LC030501* & 18.8 & +76.5 & $1.441 \mathrm{E}-04$ & 2.4 & 300 & 500 & $\mathrm{t}$ & 3 & $\mathrm{c}$ \\
90LC030601* & 314.9 & +69.7 & $3.119 \mathrm{E}-04$ & 5.6 & 300 & 500 & $\mathrm{t}$ & 3 & $\mathrm{o}$ \\
90LC030601* & 330.3 & +64.9 & $1.677 \mathrm{E}-04$ & 5.4 & 300 & 500 & $\mathrm{t}$ & 3 & $\mathrm{c}$ \\
90LC030701* & 12.3 & +47.8 & $2.826 \mathrm{E}-04$ & 11.7 & 300 & 500 & $\mathrm{t}$ & 3 & $\mathrm{o}$ \\
90LC030701* & 8.6 & +30.6 & $1.572 \mathrm{E}-04$ & 7.3 & 300 & 500 & $\mathrm{t}$ & 3 & $\mathrm{c}$
\end{tabular}


Site LS01; N.Lat: 48.06, E.Lon: 236.31, DipAz: 25, Dip: 140

\begin{tabular}{lccccccccc}
\multicolumn{1}{c}{ Sample } & Dec & Inc & R & MAD & Low & High & $\begin{array}{c}\text { Demag. } \\
\text { Method }\end{array}$ & N & $\begin{array}{c}\text { Line-Fit } \\
\text { Type }\end{array}$ \\
\hline 90LS010101 & 344.0 & -74.8 & $2.183 \mathrm{E}-03$ & 1.6 & 300 & 560 & $\mathrm{t}$ & 5 & $\mathrm{o}$ \\
90LS010101 & 348.3 & -74.6 & $1.032 \mathrm{E}-03$ & 3.1 & 300 & 560 & $\mathrm{t}$ & 5 & $\mathrm{c}$ \\
90LS010201 & 280.0 & -69.7 & $2.285 \mathrm{E}-03$ & 1.5 & 300 & 560 & $\mathrm{t}$ & 5 & $\mathrm{o}$ \\
90LS010201 & 277.1 & -70.4 & $1.070 \mathrm{E}-03$ & 3.0 & 300 & 560 & $\mathrm{t}$ & 5 & $\mathrm{c}$ \\
90LS010301 & 350.0 & -80.1 & $5.628 \mathrm{E}-03$ & 0.9 & 300 & 560 & $\mathrm{t}$ & 5 & $\mathrm{o}$ \\
90LS010301 & 354.9 & -80.1 & $3.149 \mathrm{E}-03$ & 1.3 & 300 & 560 & $\mathrm{t}$ & 5 & $\mathrm{c}$ \\
90LS010401 & 335.4 & -84.8 & $2.178 \mathrm{E}-03$ & 1.3 & 300 & 540 & $\mathrm{t}$ & 4 & $\mathrm{o}$ \\
90LS010401 & 348.4 & -84.8 & $9.977 \mathrm{E}-04$ & 2.5 & 300 & 540 & $\mathrm{t}$ & 4 & $\mathrm{c}$ \\
90LS010501 & 16.9 & -74.0 & $8.293 \mathrm{E}-03$ & 0.4 & 300 & 560 & $\mathrm{t}$ & 5 & $\mathrm{o}$ \\
90LS010501 & 18.0 & -74.2 & $4.943 \mathrm{E}-03$ & 0.5 & 300 & 560 & $\mathrm{t}$ & 5 & $\mathrm{c}$ \\
90LS010601* & 9.2 & -79.5 & $3.742 \mathrm{E}-03$ & 0.6 & 300 & 560 & $\mathrm{t}$ & 5 & $\mathrm{o}$ \\
90LS010601* & 11.7 & -79.5 & $1.912 \mathrm{E}-03$ & 1.1 & 300 & 560 & $\mathrm{t}$ & 5 & $\mathrm{c}$
\end{tabular}

Site LS02; N.Lat: 48.05, E.Lon: 236.30, DipAz: 32, Dip: 131

\begin{tabular}{|c|c|c|c|c|c|c|c|c|c|}
\hline \multirow[b]{2}{*}{ Sample } & \multirow[b]{2}{*}{$\mathrm{Dec}$} & \multirow[b]{2}{*}{ Inc } & \multirow[b]{2}{*}{$\mathbf{R}$} & \multirow[b]{2}{*}{ MAD } & \multicolumn{2}{|c|}{ Demag. Range } & \multirow{2}{*}{$\begin{array}{l}\text { Demag. } \\
\text { Method }\end{array}$} & \multirow[b]{2}{*}{$\mathrm{N}$} & \multirow[t]{2}{*}{ Line-Fit } \\
\hline & & & & & Low & High & & & \\
\hline 90LS020101* & 73.2 & +19.9 & $1.250 \mathrm{E}-03$ & 2.1 & 450 & 560 & $t$ & 4 & 0 \\
\hline 90LS020101* & 75.3 & +22.3 & 4.462E-04 & 4.8 & 450 & 560 & $t$ & 4 & c \\
\hline 90LS020201† & 104.6 & +2.1 & $6.590 \mathrm{E}-04$ & 5.1 & 300 & 500 & $t$ & 3 & o \\
\hline $90 \mathrm{LS} 020201 \dagger$ & 108.4 & +27.3 & $1.315 \mathrm{E}-04$ & 6.2 & 300 & 500 & $t$ & 3 & c \\
\hline 90LS020301 & 71.8 & +14.0 & $1.600 \mathrm{E}-02$ & 0.8 & 300 & 560 & $t$ & 5 & 0 \\
\hline 90LS020301 & 72.0 & +14.2 & $9.008 \mathrm{E}-03$ & 1.3 & 300 & 560 & $t$ & 5 & c \\
\hline 90LS020401 & 72.8 & +8.4 & $2.283 \mathrm{E}-03$ & 1.5 & 300 & 540 & $t$ & 4 & 0 \\
\hline 90LS020401 & 71.6 & +10.1 & $8.809 \mathrm{E}-04$ & 3.2 & 300 & 540 & $\mathrm{t}$ & 4 & c \\
\hline 90LS020501* & 44.9 & +9.9 & $3.578 \mathrm{E}-03$ & 1.6 & 300 & 560 & $t$ & 5 & o \\
\hline 90LS020501* & 46.2 & +10.4 & $1.932 \mathrm{E}-03$ & 2.5 & 300 & 560 & $t$ & 5 & c \\
\hline 90LS020601* & 82.1 & +4.0 & $1.464 \mathrm{E}-03$ & 1.9 & 300 & 540 & $t$ & 4 & 0 \\
\hline 90LS020601* & 81.7 & +6.7 & $5.661 \mathrm{E}-04$ & 4.0 & 300 & 540 & $t$ & 4 & c \\
\hline 90LS020701* & 49.2 & +34.5 & $9.988 \mathrm{E}-03$ & 1.2 & 300 & 560 & t & 5 & o \\
\hline 90LS020701* & 49.0 & +34.7 & $5.441 \mathrm{E}-03$ & 2.1 & 300 & 560 & $t$ & 5 & c \\
\hline 90LS020801 & 64.4 & +21.6 & $9.416 \mathrm{E}-03$ & 1.9 & 300 & 540 & $t$ & 4 & 0 \\
\hline 90LS020801 & 64.0 & +23.2 & $3.854 \mathrm{E}-03$ & 4.2 & 300 & 540 & $\mathrm{t}$ & 4 & c \\
\hline
\end{tabular}


Site LS03; N.Lat: 48.05, E.Lon: 236.29, DipAz: 358, Dip: 117

\begin{tabular}{cccccccccc} 
Sample & Dec & Inc & R & MAD & Low & High & Method & N & Type \\
\hline 90LS030101* & 71.4 & +29.7 & $1.958 \mathrm{E}-04$ & 1.7 & 25 & 50 & $\mathrm{a}$ & 6 & $\mathrm{o}$ \\
90LS030101* & 71.8 & +30.9 & $1.204 \mathrm{E}-04$ & 2.2 & 25 & 50 & $\mathrm{a}$ & 6 & $\mathrm{c}$ \\
90LS030201* & 73.3 & +28.4 & $2.688 \mathrm{E}-03$ & 0.8 & 450 & 560 & $\mathrm{t}$ & 4 & $\mathrm{o}$ \\
90LS030201* & 73.0 & +29.6 & $1.143 \mathrm{E}-03$ & 1.2 & 450 & 560 & $\mathrm{t}$ & 4 & $\mathrm{c}$ \\
90LS030301* & 75.1 & +28.8 & $2.996 \mathrm{E}-03$ & 1.9 & 300 & 540 & $\mathrm{t}$ & 4 & $\mathrm{o}$ \\
90LS030301* & 75.7 & +29.4 & $9.937 \mathrm{E}-04$ & 5.7 & 300 & 540 & $\mathrm{t}$ & 4 & $\mathrm{c}$ \\
90LS030401* & 63.2 & +26.4 & $1.369 \mathrm{E}-03$ & 2.1 & 300 & 540 & $\mathrm{t}$ & 4 & $\mathrm{o}$ \\
90LS030401* & 57.6 & +27.0 & $4.626 \mathrm{E}-04$ & 3.5 & 300 & 540 & $\mathrm{t}$ & 4 & $\mathrm{c}$ \\
90LS030501* & 72.0 & +34.5 & $3.303 \mathrm{E}-03$ & 4.5 & 150 & 500 & $\mathrm{t}$ & 8 & $\mathrm{o}$ \\
90LS030501* & 98.7 & +82.2 & $3.348 \mathrm{E}-04$ & 14.8 & 150 & 500 & $\mathrm{t}$ & 8 & $\mathrm{c}$ \\
90LS030601* & 80.8 & +25.0 & $5.022 \mathrm{E}-03$ & 0.8 & 300 & 500 & $\mathrm{t}$ & 3 & $\mathrm{o}$ \\
90LS030601* & 72.7 & +19.0 & $3.650 \mathrm{E}-04$ & 6.1 & 300 & 500 & $\mathrm{t}$ & 3 & $\mathrm{c}$ \\
90LS030701* & 72.3 & +29.1 & $8.927 \mathrm{E}-04$ & 1.8 & 450 & 560 & $\mathrm{t}$ & 4 & $\mathrm{o}$ \\
90LS030701* & 71.6 & +30.4 & $4.366 \mathrm{E}-04$ & 3.2 & 450 & 560 & $\mathrm{t}$ & 4 & $\mathrm{c}$
\end{tabular}

Site LS04; N.Lat: 48.05, E.Lon: 236.29, DipAz: 10, Dip: 128

\begin{tabular}{|c|c|c|c|c|c|c|c|c|c|}
\hline \multirow[b]{2}{*}{ Sample } & \multirow[b]{2}{*}{ Dec } & \multirow[b]{2}{*}{ Inc } & \multirow[b]{2}{*}{$\mathbf{R}$} & \multirow[b]{2}{*}{ MAD } & \multicolumn{2}{|c|}{ Demag. Range } & \multirow{2}{*}{$\begin{array}{l}\text { Demag. } \\
\text { Method }\end{array}$} & \multirow[b]{2}{*}{$\mathrm{N}$} & \multirow{2}{*}{$\begin{array}{c}\text { Line-Fit } \\
\text { Type }\end{array}$} \\
\hline & & & & & Low & High & & & \\
\hline 90LS040101* & 43.8 & +13.0 & $2.487 \mathrm{E}-04$ & 6.5 & 300 & 540 & $t$ & 4 & 0 \\
\hline 90LS040101* & 40.9 & +8.0 & $1.013 \mathrm{E}-04$ & 14.4 & 300 & 540 & $t$ & 4 & c \\
\hline 90LS040201* & 68.0 & +36.4 & $3.089 \mathrm{E}-02$ & 0.7 & 300 & 560 & $t$ & 5 & 0 \\
\hline 90LS040201* & 68.3 & +36.2 & $1.665 \mathrm{E}-02$ & 1.2 & 300 & 560 & $\mathrm{t}$ & 5 & c \\
\hline 90LS040301* & 40.9 & +4.3 & $3.298 \mathrm{E}-04$ & 6.0 & 300 & 560 & $t$ & 5 & 0 \\
\hline 90LS040301* & 38.4 & +6.5 & $1.655 \mathrm{E}-04$ & 11.1 & 300 & 560 & $\mathrm{t}$ & 5 & c \\
\hline 90LS040401* & 78.7 & +33.5 & $8.966 \mathrm{E}-04$ & 4.8 & 300 & 560 & $\mathrm{t}$ & 5 & 0 \\
\hline 90LS040401* & 83.4 & +36.2 & 4.683E-04 & 7.4 & 300 & 560 & $\mathrm{t}$ & 5 & c \\
\hline 90LS040501* & 81.8 & +20.4 & $1.660 \mathrm{E}-03$ & 3.3 & 300 & 560 & $t$ & 5 & 0 \\
\hline 90LS040501* & 79.6 & +19.4 & $9.052 \mathrm{E}-04$ & 5.5 & 300 & 560 & $t$ & 5 & c \\
\hline 90LS040601* & 118.7 & +19.5 & $3.443 \mathrm{E}-03$ & 1.2 & 450 & 560 & $t$ & 4 & 0 \\
\hline 90LS040601* & 117.5 & +18.5 & $1.915 \mathrm{E}-03$ & 1.1 & 450 & 560 & $\mathrm{t}$ & 4 & c \\
\hline 90LS040701 & 99.0 & +41.9 & $5.205 E-03$ & 1.9 & 300 & 600 & $\mathrm{t}$ & 10 & o \\
\hline 90LS040701 & 93.9 & +40.3 & $1.840 \mathrm{E}-03$ & 3.0 & 300 & 600 & $t$ & 10 & c \\
\hline 90LS040801† & 1.4 & +34.6 & $6.226 \mathrm{E}-03$ & 1.3 & 300 & 540 & $t$ & 4 & 0 \\
\hline 90LS040801† & 2.1 & +37.0 & $2.240 \mathrm{E}-03$ & 2.3 & 300 & 540 & $\mathrm{t}$ & 4 & c \\
\hline
\end{tabular}


Site LS05; N.Lat: 48.05, E.Lon: 236.30, DipAz: 40, Dip: 125

\begin{tabular}{lccccccccc}
\multicolumn{1}{c}{ Sample } & Dec & Inc & R & MAD & Low & High & $\begin{array}{c}\text { Demag. Range } \\
\text { Method }\end{array}$ & N & Line-Fit \\
\hline 90LS050101 & 259.1 & +52.9 & $7.810 \mathrm{E}-04$ & 2.8 & 300 & 560 & $\mathrm{t}$ & 5 & $\mathrm{o}$ \\
90LS050101 & 261.3 & +58.3 & $2.983 \mathrm{E}-04$ & 4.1 & 300 & 560 & $\mathrm{t}$ & 5 & $\mathrm{c}$ \\
90LS050201* & 237.3 & +24.8 & $1.002 \mathrm{E}-03$ & 4.0 & 300 & 540 & $\mathrm{t}$ & 4 & $\mathrm{o}$ \\
90LS050201* & 226.4 & +29.0 & $2.798 \mathrm{E}-04$ & 9.5 & 300 & 540 & $\mathrm{t}$ & 4 & $\mathrm{c}$ \\
90LS050301* & 259.4 & +28.3 & $9.043 \mathrm{E}-04$ & 3.7 & 300 & 560 & $\mathrm{t}$ & 7 & $\mathrm{o}$ \\
90LS050301* & 259.5 & +33.7 & $2.523 \mathrm{E}-04$ & 11.8 & 300 & 560 & $\mathrm{t}$ & 7 & $\mathrm{c}$ \\
90LS050401* & 242.3 & +22.7 & $6.000 \mathrm{E}-04$ & 3.5 & 450 & 560 & $\mathrm{t}$ & 4 & $\mathrm{o}$ \\
90LS050401* & 248.1 & +25.7 & $2.241 \mathrm{E}-04$ & 6.6 & 450 & 560 & $\mathrm{t}$ & 4 & $\mathrm{c}$ \\
90LS050501* & 260.3 & +23.6 & $1.069 \mathrm{E}-03$ & 4.0 & 300 & 500 & $\mathrm{t}$ & 3 & $\mathrm{o}$ \\
90LS050501* & 244.0 & +53.4 & $1.388 \mathrm{E}-04$ & 1.1 & 300 & 500 & $\mathrm{t}$ & 3 & $\mathrm{c}$ \\
90LS050601* & 252.8 & +17.4 & $1.182 \mathrm{E}-03$ & 5.5 & 300 & 560 & $\mathrm{t}$ & 5 & $\mathrm{o}$ \\
90LS050601* & 260.1 & +33.1 & $3.283 \mathrm{E}-04$ & 9.4 & 300 & 560 & $\mathrm{t}$ & 5 & $\mathrm{c}$ \\
90LS050701* & 252.3 & +14.7 & $8.746 \mathrm{E}-04$ & 1.9 & 450 & 560 & $\mathrm{t}$ & 4 & $\mathrm{o}$ \\
90LS050701* & 253.7 & +16.3 & $4.265 \mathrm{E}-04$ & 2.9 & 450 & 560 & $\mathrm{t}$ & 4 & $\mathrm{c}$
\end{tabular}

Site LS06; N.Lat: 48.05, E.Lon: 236.30, DipAz: 32, Dip: 131

\begin{tabular}{lccccccccc}
\multicolumn{1}{c}{ Sample } & Dec & Inc & R & MAD & Low & High & Method & N & Type \\
\hline 90LS060101 & 56.3 & +26.0 & $3.528 \mathrm{E}-03$ & 1.8 & 300 & 575 & $\mathrm{t}$ & 6 & $\mathrm{o}$ \\
90LS060101 & 57.6 & +28.8 & $1.074 \mathrm{E}-03$ & 5.0 & 300 & 575 & $\mathrm{t}$ & 6 & $\mathrm{c}$ \\
90LS060201* & 55.0 & +42.3 & $4.612 \mathrm{E}-04$ & 3.1 & 300 & 575 & $\mathrm{t}$ & 6 & $\mathrm{o}$ \\
90LS060201* & 48.8 & +43.4 & $1.784 \mathrm{E}-04$ & 6.2 & 300 & 575 & $\mathrm{t}$ & 6 & $\mathrm{c}$ \\
90LS060301* & 57.4 & +35.9 & $7.619 \mathrm{E}-03$ & 1.7 & 300 & 560 & $\mathrm{t}$ & 5 & $\mathrm{o}$ \\
90LS060301* & 56.7 & +35.3 & $4.080 \mathrm{E}-03$ & 2.9 & 300 & 560 & $\mathrm{t}$ & 5 & $\mathrm{c}$ \\
90LS060401* & 48.4 & +38.4 & $2.164 \mathrm{E}-03$ & 1.7 & 300 & 560 & $\mathrm{t}$ & 5 & $\mathrm{o}$ \\
90LS060401* & 45.1 & +41.1 & $7.724 \mathrm{E}-04$ & 2.6 & 300 & 560 & $\mathrm{t}$ & 5 & $\mathrm{c}$ \\
90LS060501 & 65.3 & +29.2 & $3.192 \mathrm{E}-03$ & 1.2 & 300 & 580 & $\mathrm{t}$ & 9 & $\mathrm{o}$ \\
90LS060501 & 65.0 & +30.3 & $1.133 \mathrm{E}-03$ & 3.3 & 300 & 580 & $\mathrm{t}$ & 9 & $\mathrm{c}$ \\
90LS060601* & 73.3 & +26.8 & $6.880 \mathrm{E}-04$ & 2.0 & 300 & 560 & $\mathrm{t}$ & 5 & $\mathrm{o}$ \\
90LS060601* & 71.1 & +26.4 & $3.098 \mathrm{E}-04$ & 3.8 & 300 & 560 & $\mathrm{t}$ & 5 & $\mathrm{c}$ \\
90LS060701 & 58.1 & +19.5 & $1.688 \mathrm{E}-03$ & 1.1 & 300 & 560 & $\mathrm{t}$ & 5 & $\mathrm{o}$ \\
90LS060701 & 57.6 & +20.9 & $6.238 \mathrm{E}-04$ & 2.6 & 300 & 560 & $\mathrm{t}$ & 5 & $\mathrm{c}$ \\
90LS060801 & 65.4 & +41.1 & $3.791 \mathrm{E}-03$ & 0.6 & 300 & 560 & $\mathrm{t}$ & 5 & $\mathrm{o}$ \\
90LS060801 & 65.5 & +41.1 & $1.784 \mathrm{E}-03$ & 1.2 & 300 & 560 & $\mathrm{t}$ & 5 & $\mathrm{c}$ \\
90LS060901* & 59.2 & +33.1 & $2.073 \mathrm{E}-03$ & 1.4 & 300 & 560 & $\mathrm{t}$ & 5 & $\mathrm{o}$ \\
90LS060901* & 57.6 & +35.1 & $7.106 \mathrm{E}-04$ & 3.3 & 300 & 560 & $\mathrm{t}$ & 5 & $\mathrm{c}$
\end{tabular}


Site MP01; N.Lat: 47.92, E.Lon: 236.89, DipAz: 38, Dip: 62

\begin{tabular}{lrrccccccc}
\multicolumn{1}{c}{ Sample } & \multicolumn{1}{c}{ Dec } & \multicolumn{1}{c}{ Inc } & R & MAD & Demag. Range & Low & Demag. & & Line-Fit \\
Method & N & Type \\
\hline 90MP010101 & 350.4 & -67.1 & $1.308 \mathrm{E}-02$ & 2.0 & 300 & 540 & $\mathrm{t}$ & 4 & $\mathrm{o}$ \\
90MP010101 & 0.7 & -61.8 & $3.417 \mathrm{E}-03$ & 2.5 & 300 & 540 & $\mathrm{t}$ & 4 & $\mathrm{c}$ \\
90MP010201 & 23.2 & -74.4 & $5.374 \mathrm{E}-03$ & 3.2 & 300 & 560 & $\mathrm{t}$ & 5 & $\mathrm{o}$ \\
90MP010201 & 29.0 & -70.5 & $1.830 \mathrm{E}-03$ & 8.1 & 300 & 560 & $\mathrm{t}$ & 5 & $\mathrm{c}$ \\
90MP010301 & 58.4 & -88.4 & $2.844 \mathrm{E}-03$ & 1.5 & 300 & 560 & $\mathrm{t}$ & 5 & $\mathrm{o}$ \\
90MP010301 & 34.2 & -87.6 & $1.277 \mathrm{E}-03$ & 3.0 & 300 & 560 & $\mathrm{t}$ & 5 & $\mathrm{c}$ \\
90MP010401 & 23.7 & -56.1 & $1.902 \mathrm{E}-02$ & 0.6 & 300 & 540 & $\mathrm{t}$ & 4 & $\mathrm{o}$ \\
90MP010401 & 23.8 & -55.0 & $5.690 \mathrm{E}-03$ & 1.5 & 300 & 540 & $\mathrm{t}$ & 4 & $\mathrm{c}$ \\
90MP010501 & 29.5 & -63.4 & $2.087 \mathrm{E}-02$ & 1.2 & 300 & 540 & $\mathrm{t}$ & 4 & $\mathrm{o}$ \\
90MP010501 & 25.7 & -63.0 & $7.628 \mathrm{E}-03$ & 2.7 & 300 & 540 & $\mathrm{t}$ & 4 & $\mathrm{c}$ \\
90MP010601† & 59.7 & -45.4 & $3.920 \mathrm{E}-03$ & 1.6 & 400 & 560 & $\mathrm{t}$ & 5 & $\mathrm{o}$ \\
90MP010601 $\dagger$ & 58.7 & -43.9 & $1.573 \mathrm{E}-03$ & 3.6 & 400 & 560 & $\mathrm{t}$ & 5 & $\mathrm{c}$ \\
90MP010701 & 42.6 & -81.1 & $4.283 \mathrm{E}-03$ & 5.8 & 300 & 560 & $\mathrm{t}$ & 5 & $\mathrm{o}$ \\
90MP010701 & 52.2 & -77.5 & $1.850 \mathrm{E}-03$ & 12.5 & 300 & 560 & $\mathrm{t}$ & 5 & $\mathrm{c}$ \\
90MP010801 & 94.6 & -73.3 & $7.291 \mathrm{E}-03$ & 3.0 & 450 & 560 & $\mathrm{t}$ & 4 & $\mathrm{o}$ \\
90MP010801 & 82.0 & -73.1 & $3.669 \mathrm{E}-03$ & 4.3 & 450 & 560 & $\mathrm{t}$ & 4 & $\mathrm{c}$
\end{tabular}

Site MP02; N.Lat: 47.91, E.Lon: 236.89, DipAz: 60, Dip: 90

\begin{tabular}{|c|c|c|c|c|c|c|c|c|c|}
\hline \multirow[b]{2}{*}{ Sample } & \multirow[b]{2}{*}{ Dec } & \multirow[b]{2}{*}{ Inc } & \multirow[b]{2}{*}{$\mathbf{R}$} & \multirow[b]{2}{*}{ MAD } & \multicolumn{2}{|c|}{ Demag. Range } & \multirow{2}{*}{$\begin{array}{l}\text { Demag. } \\
\text { Method }\end{array}$} & \multirow[b]{2}{*}{$\mathrm{N}$} & \multirow{2}{*}{$\begin{array}{c}\text { Line-Fit } \\
\text { Type }\end{array}$} \\
\hline & & & & & Low & High & & & \\
\hline 90MP020101 & 66.7 & -5.0 & $2.566 \mathrm{E}-03$ & 0.7 & 300 & 540 & $t$ & 4 & 0 \\
\hline 90MP020101 & 65.8 & -5.0 & $1.293 \mathrm{E}-03$ & 0.9 & 300 & 540 & $t$ & 4 & c \\
\hline 90MP020201 & 65.2 & -6.9 & $2.720 \mathrm{E}-03$ & 1.8 & 300 & 540 & $\mathrm{t}$ & 4 & o \\
\hline 90MP020201 & 62.6 & -7.3 & $1.148 \mathrm{E}-03$ & 3.3 & 300 & 540 & $t$ & 4 & c \\
\hline 90MP020301 & 62.3 & -1.5 & $1.025 \mathrm{E}-03$ & 0.6 & 300 & 540 & $\mathrm{t}$ & 6 & 0 \\
\hline 90MP020301 & 63.0 & -2.5 & $3.903 \mathrm{E}-04$ & 1.0 & 300 & 540 & $t$ & 6 & c \\
\hline 90MP020401 & 68.2 & -.1 & $2.385 \mathrm{E}-03$ & 0.9 & 450 & 560 & $t$ & 4 & 0 \\
\hline 90MP020401 & 68.8 & -.7 & $1.036 \mathrm{E}-03$ & 1.8 & 450 & 560 & $\mathrm{t}$ & 4 & c \\
\hline 90MP020501 & 69.7 & -4.0 & $2.319 \mathrm{E}-03$ & 1.1 & 300 & 575 & $t$ & 6 & 0 \\
\hline 90MP020501 & 68.6 & -3.7 & $1.289 \mathrm{E}-03$ & 1.5 & 300 & 575 & $t$ & 6 & c \\
\hline 90MP020601 & 63.9 & -2.6 & $6.044 \mathrm{E}-04$ & 1.5 & 300 & 540 & $t$ & 4 & o \\
\hline 90MP020601 & 61.8 & +2.0 & $1.549 \mathrm{E}-04$ & 2.7 & 300 & 540 & $t$ & 4 & c \\
\hline 90MP020701 & 58.5 & -.5 & $1.627 \mathrm{E}-03$ & 1.3 & 450 & 560 & $\mathrm{t}$ & 4 & 0 \\
\hline 90MP020701 & 58.1 & -.2 & $9.276 \mathrm{E}-04$ & 2.1 & 450 & 560 & $t$ & 4 & c \\
\hline 90MP020801 & 65.1 & -3.7 & $1.874 \mathrm{E}-03$ & 0.8 & 300 & 540 & $t$ & 4 & 0 \\
\hline 90MP020801 & 66.0 & -3.1 & 8.633E-04 & 1.2 & 300 & 540 & $t$ & 4 & c \\
\hline
\end{tabular}


Site MP03; N.Lat: 47.91, E.Lon: 236.88, DipAz: 42, Dip: 95

\begin{tabular}{|c|c|c|c|c|c|c|c|c|c|}
\hline Sample & Dec & Inc & $\mathbf{R}$ & MAD & $\begin{array}{l}\text { Demag } \\
\text { Low }\end{array}$ & $\begin{array}{l}\text { ange } \\
\text { High }\end{array}$ & $\begin{array}{l}\text { Demag. } \\
\text { Method }\end{array}$ & $\mathrm{N}$ & $\begin{array}{c}\text { Line-Fit } \\
\text { Type }\end{array}$ \\
\hline 90MP030101 & 77.4 & -12.1 & $2.506 \mathrm{E}-03$ & 3.7 & 450 & 560 & $t$ & 4 & 0 \\
\hline 90MP030101 & 73.6 & -10.5 & $1.176 \mathrm{E}-03$ & 6.4 & 450 & 560 & $\mathrm{t}$ & 4 & c \\
\hline 90MP030201 & 56.6 & -13.8 & $1.838 \mathrm{E}-03$ & 3.7 & 300 & 540 & $\mathrm{t}$ & 4 & 0 \\
\hline 90MP030201 & 55.9 & -6.4 & $8.086 \mathrm{E}-04$ & 2.0 & 300 & 540 & $\mathrm{t}$ & 4 & c \\
\hline 90MP030301 & 56.5 & -27.0 & $9.081 \mathrm{E}-04$ & 5.3 & 300 & 560 & $\mathrm{t}$ & 5 & 0 \\
\hline 90MP030301 & 54.9 & -21.5 & $4.121 \mathrm{E}-04$ & 9.8 & 300 & 560 & $\mathrm{t}$ & 5 & c \\
\hline 90MP030401 & 48.1 & -19.2 & $3.527 \mathrm{E}-03$ & 1.5 & 300 & 540 & $\mathrm{t}$ & 4 & 0 \\
\hline 90MP030401 & 44.2 & -19.0 & 8.734E-04 & 4.7 & 300 & 540 & $\mathrm{t}$ & 4 & c \\
\hline 90MP030501 & 50.6 & -9.9 & $5.353 \mathrm{E}-04$ & 2.8 & 400 & 560 & $t$ & 5 & 0 \\
\hline 90MP030501 & 49.0 & -5.7 & $1.716 \mathrm{E}-04$ & 7.3 & 400 & 560 & $t$ & 5 & c \\
\hline 90MP030601 & 80.4 & +22.9 & $3.444 \mathrm{E}-03$ & 2.3 & 300 & 540 & $\mathrm{t}$ & 4 & 0 \\
\hline 90MP030601 & 78.1 & +19.8 & $1.616 \mathrm{E}-03$ & 2.3 & 300 & 540 & $\mathrm{t}$ & 4 & c \\
\hline 90MP030701 & 63.5 & +2.5 & $2.284 \mathrm{E}-03$ & 4.1 & 300 & 540 & $t$ & 4 & 0 \\
\hline $90 \mathrm{MP0} 30701$ & 61.6 & +11.1 & $6.917 \mathrm{E}-04$ & 9.9 & 300 & 540 & $t$ & 4 & c \\
\hline 90MP030801 & 33.1 & -9.2 & $9.128 \mathrm{E}-03$ & 2.2 & 300 & 540 & $t$ & 4 & 0 \\
\hline 90MP030801 & 35.3 & -12.1 & $2.813 \mathrm{E}-03$ & 6.0 & 300 & 540 & $t$ & 4 & c \\
\hline
\end{tabular}

Site PM01; N.Lat: 48.07, E.Lon: 236.19, DipAz: 50, Dip: 46

\begin{tabular}{cccccccccc} 
Sample & Dec & Inc & R & MAD & Low & High & Method & N & $\begin{array}{c}\text { Line-Fit } \\
\text { Type }\end{array}$ \\
\hline 90PM010101 & 267.2 & +19.3 & $2.209 \mathrm{E}-03$ & 0.7 & 300 & 560 & $\mathrm{t}$ & 7 & $\mathrm{o}$ \\
90PM010101 & 268.1 & +19.5 & $1.073 \mathrm{E}-03$ & 0.8 & 300 & 560 & $\mathrm{t}$ & 7 & $\mathrm{c}$ \\
90PM010201 & 257.2 & +26.1 & $4.127 \mathrm{E}-03$ & 0.5 & 300 & 540 & $\mathrm{t}$ & 4 & $\mathrm{o}$ \\
90PM010201 & 257.3 & +26.0 & $2.668 \mathrm{E}-03$ & 0.8 & 300 & 540 & $\mathrm{t}$ & 4 & $\mathrm{c}$ \\
90PM010301 & 254.0 & +11.6 & $8.722 \mathrm{E}-03$ & 0.5 & 300 & 540 & $\mathrm{t}$ & 4 & $\mathrm{o}$ \\
90PM010301 & 254.0 & +11.6 & $4.374 \mathrm{E}-03$ & 1.1 & 300 & 540 & $\mathrm{t}$ & 4 & $\mathrm{c}$ \\
90PM010401 & 260.9 & +26.8 & $5.708 \mathrm{E}-04$ & 1.4 & 300 & 540 & $\mathrm{t}$ & 4 & $\mathrm{o}$ \\
90PM010401 & 259.8 & +26.8 & $4.437 \mathrm{E}-04$ & 0.8 & 300 & 540 & $\mathrm{t}$ & 4 & $\mathrm{c}$ \\
90PM010501 & 263.4 & +33.2 & $1.930 \mathrm{E}-03$ & 1.5 & 300 & 560 & $\mathrm{t}$ & 5 & $\mathrm{o}$ \\
90PM010501 & 262.4 & +34.3 & $1.158 \mathrm{E}-03$ & 1.9 & 300 & 560 & $\mathrm{t}$ & 5 & $\mathrm{c}$ \\
90PM010601 & 259.1 & +17.7 & $6.968 \mathrm{E}-03$ & 0.6 & 300 & 540 & $\mathrm{t}$ & 4 & $\mathrm{o}$ \\
90PM010601 & 259.5 & +17.0 & $3.179 \mathrm{E}-03$ & 1.1 & 300 & 540 & $\mathrm{t}$ & 4 & $\mathrm{c}$ \\
90PM010701 & 256.6 & +10.8 & $2.489 \mathrm{E}-03$ & 1.3 & 300 & 575 & $\mathrm{t}$ & 6 & $\mathrm{o}$ \\
90PM010701 & 255.9 & +10.2 & $1.413 \mathrm{E}-03$ & 1.9 & 300 & 575 & $\mathrm{t}$ & 6 & $\mathrm{c}$
\end{tabular}


Site PM02; N.Lat: 48.08, E.Lon: 236.14, DipAz: 30, Dip: 60

\begin{tabular}{lrrccccccc}
\multicolumn{1}{c}{ Sample } & \multicolumn{1}{c}{ Dec } & Inc & R & MAD & \multicolumn{2}{c}{ Demag. Range } & Demag. & \multicolumn{2}{c}{ Line-Fit } \\
90PM020101 & 221.0 & +27.8 & $3.600 \mathrm{E}-02$ & 0.9 & 300 & 560 & $\mathrm{t}$ & 5 & $\mathrm{o}$ \\
90PM020101 & 219.4 & +28.3 & $1.520 \mathrm{E}-02$ & 1.4 & 300 & 560 & $\mathrm{t}$ & 5 & $\mathrm{c}$ \\
90PM020201 & 212.1 & +39.7 & $3.149 \mathrm{E}-03$ & 1.5 & 300 & 540 & $\mathrm{t}$ & 4 & $\mathrm{o}$ \\
90PM020201 & 213.5 & +37.3 & $1.398 \mathrm{E}-03$ & 1.6 & 300 & 540 & $\mathrm{t}$ & 4 & $\mathrm{c}$ \\
90PM020302† & 313.2 & -13.8 & $7.836 \mathrm{E}-03$ & 0.4 & 300 & 540 & $\mathrm{t}$ & 5 & $\mathrm{o}$ \\
90PM020302† & 313.0 & -13.9 & $4.807 \mathrm{E}-03$ & 0.6 & 300 & 540 & $\mathrm{t}$ & 5 & $\mathrm{c}$ \\
90PM020401 & 223.2 & +32.6 & $5.775 \mathrm{E}-03$ & 1.8 & 300 & 540 & $\mathrm{t}$ & 4 & $\mathrm{o}$ \\
90PM020401 & 223.4 & +33.1 & $2.781 \mathrm{E}-03$ & 3.8 & 300 & 540 & $\mathrm{t}$ & 4 & $\mathrm{c}$ \\
90PM020501 & 226.5 & +31.2 & $8.099 \mathrm{E}-02$ & 0.4 & 0 & 500 & $\mathrm{t}$ & 4 & $\mathrm{o}$ \\
90PM020501 & 46.5 & -33.7 & $1.267 \mathrm{E}-02$ & 1.3 & 0 & 500 & $\mathrm{t}$ & 4 & $\mathrm{c}$ \\
90PM020601 & 218.2 & +31.2 & $2.747 \mathrm{E}-02$ & 0.9 & 300 & 540 & $\mathrm{t}$ & 4 & $\mathrm{o}$ \\
90PM020601 & 217.8 & +31.2 & $1.361 \mathrm{E}-02$ & 1.9 & 300 & 540 & $\mathrm{t}$ & 4 & $\mathrm{c}$ \\
90PM020701 & 211.9 & +29.0 & $2.961 \mathrm{E}-02$ & 0.4 & 300 & 540 & $\mathrm{t}$ & 4 & $\mathrm{o}$ \\
90PM020701 & 31.2 & -29.4 & $1.314 \mathrm{E}-02$ & 0.4 & 300 & 540 & $\mathrm{t}$ & 4 & $\mathrm{c}$
\end{tabular}

Site PM03; N.Lat: 48.08, E.Lon: 236.14, DipAz: 10, Dip: 74

\begin{tabular}{lrrccccccc}
\multicolumn{1}{c}{ Sample } & \multicolumn{1}{c}{ Dec } & \multicolumn{1}{c}{ Inc } & R & MAD & \multicolumn{2}{c}{ Lemag. Range } & Demag. & \multicolumn{2}{c}{ Line-Fit } \\
\hline 90PM030102 & 186.9 & +43.6 & $1.021 \mathrm{E}-03$ & 2.0 & 300 & 540 & $\mathrm{t}$ & 4 & $\mathrm{o}$ \\
90PM030102 & 190.6 & +41.9 & $3.941 \mathrm{E}-04$ & 3.8 & 300 & 540 & $\mathrm{t}$ & 4 & $\mathrm{c}$ \\
90PM030202 & 6.8 & -28.2 & $3.350 \mathrm{E}-03$ & 1.0 & 300 & 540 & $\mathrm{t}$ & 4 & $\mathrm{o}$ \\
90PM030202 & 186.8 & +28.5 & $1.503 \mathrm{E}-03$ & 2.1 & 300 & 540 & $\mathrm{t}$ & 4 & $\mathrm{c}$ \\
90PM030302† & 342.5 & +3.2 & $1.291 \mathrm{E}-02$ & 1.1 & 300 & 500 & $\mathrm{t}$ & 3 & $\mathrm{o}$ \\
90PM030302† & 342.4 & +3.9 & $2.654 \mathrm{E}-03$ & 5.5 & 300 & 500 & $\mathrm{t}$ & 3 & $\mathrm{c}$ \\
90PM030402 & 192.3 & +33.5 & $4.805 \mathrm{E}-03$ & 0.4 & 300 & 500 & $\mathrm{t}$ & 3 & $\mathrm{o}$ \\
90PM030402 & 192.9 & +33.4 & $2.855 \mathrm{E}-03$ & 0.3 & 300 & 500 & $\mathrm{t}$ & 3 & $\mathrm{c}$ \\
90PM030502 & 190.2 & +32.4 & $1.278 \mathrm{E}-02$ & 1.7 & 300 & 540 & $\mathrm{t}$ & 4 & $\mathrm{o}$ \\
90PM030502 & 190.2 & +33.6 & $5.768 \mathrm{E}-03$ & 3.5 & 300 & 540 & $\mathrm{t}$ & 4 & $\mathrm{c}$ \\
90PM030601 & 195.3 & +45.1 & $4.141 \mathrm{E}-03$ & 1.2 & 300 & 540 & $\mathrm{t}$ & 6 & $\mathrm{o}$ \\
90PM030601 & 196.2 & +45.4 & $1.860 \mathrm{E}-03$ & 2.5 & 300 & 540 & $\mathrm{t}$ & 6 & $\mathrm{c}$ \\
90PM030702 & 193.8 & +46.8 & $2.593 \mathrm{E}-03$ & 1.5 & 300 & 500 & $\mathrm{t}$ & 3 & $\mathrm{o}$ \\
90PM030702 & 195.8 & +46.2 & $1.767 \mathrm{E}-03$ & 0.9 & 300 & 500 & $\mathrm{t}$ & 3 & $\mathrm{c}$
\end{tabular}


Site PM04; N.Lat: 48.08, E.Lon: 236.09, DipAz: 32, Dip: 87

\begin{tabular}{crcccccccc} 
Sample & \multicolumn{1}{c}{ Dec } & \multicolumn{1}{c}{ Inc } & R & MAD & \multicolumn{2}{c}{ Demag. Range } & Demag. & \multicolumn{2}{c}{ Line-Fit } \\
90PM040101 & 244.4 & +19.3 & $3.327 \mathrm{E}-03$ & 2.2 & 300 & 560 & $\mathrm{t}$ & 5 & $\mathrm{o}$ \\
90PM040101 & 245.2 & +21.3 & $1.748 \mathrm{E}-03$ & 3.3 & 300 & 560 & $\mathrm{t}$ & 5 & $\mathrm{c}$ \\
90PM040201 & 234.5 & +33.3 & $2.454 \mathrm{E}-02$ & 0.5 & 300 & 560 & $\mathrm{t}$ & 5 & $\mathrm{o}$ \\
90PM040201 & 54.7 & -33.1 & $1.563 \mathrm{E}-02$ & 0.7 & 300 & 560 & $\mathrm{t}$ & 5 & $\mathrm{c}$ \\
90PM040301 & 241.5 & +38.5 & $2.990 \mathrm{E}-03$ & 1.7 & 300 & 575 & $\mathrm{t}$ & 6 & $\mathrm{o}$ \\
90PM040301 & 239.7 & +38.3 & $1.721 \mathrm{E}-03$ & 2.4 & 300 & 575 & $\mathrm{t}$ & 6 & $\mathrm{c}$ \\
90PM040401 & 241.1 & +27.0 & $4.882 \mathrm{E}-03$ & 1.5 & 300 & 560 & $\mathrm{t}$ & 5 & $\mathrm{o}$ \\
90PM040401 & 240.1 & +27.6 & $3.035 \mathrm{E}-03$ & 2.1 & 300 & 560 & $\mathrm{t}$ & 5 & $\mathrm{c}$ \\
90PM040501 & 66.2 & -39.3 & $5.645 \mathrm{E}-03$ & 1.5 & 300 & 540 & $\mathrm{t}$ & 4 & $\mathrm{o}$ \\
90PM040501 & 246.3 & +39.3 & $2.972 \mathrm{E}-03$ & 2.8 & 300 & 540 & $\mathrm{t}$ & 4 & $\mathrm{c}$ \\
90PM040601 & 240.8 & +34.5 & $2.957 \mathrm{E}-03$ & 3.0 & 300 & 560 & $\mathrm{t}$ & 7 & $\mathrm{o}$ \\
90PM040601 & 240.3 & +36.9 & $1.129 \mathrm{E}-03$ & 7.5 & 300 & 560 & $\mathrm{t}$ & 7 & $\mathrm{c}$ \\
90PM040701 & 256.3 & +21.4 & $1.648 \mathrm{E}-03$ & 2.0 & 300 & 560 & $\mathrm{t}$ & 5 & $\mathrm{o}$ \\
90PM040701 & 255.8 & +23.3 & $9.009 \mathrm{E}-04$ & 2.8 & 300 & 560 & $\mathrm{t}$ & 5 & $\mathrm{c}$
\end{tabular}

Site PM05; N.Lat: 48.08, E.Lon: 236.08, DipAz: 22, Dip: 84

\begin{tabular}{lrrccccccc}
\multicolumn{1}{c}{ Sample } & \multicolumn{1}{c}{ Dec } & \multicolumn{1}{c}{ Inc } & R & MAD & \multicolumn{2}{c}{ Demag. Range } & Demag. & \multicolumn{2}{c}{ Line-Fit } \\
High & Method & N & Type \\
\hline 90PM050101 & 261.0 & +57.2 & $2.175 \mathrm{E}-03$ & 3.6 & 300 & 540 & $\mathrm{t}$ & 4 & $\mathrm{o}$ \\
90PM050101 & 264.2 & +58.1 & $1.290 \mathrm{E}-03$ & 5.5 & 300 & 540 & $\mathrm{t}$ & 4 & $\mathrm{c}$ \\
90PM050201 & 215.1 & +42.4 & $1.153 \mathrm{E}-02$ & 3.1 & 0 & 500 & $\mathrm{t}$ & 4 & $\mathrm{o}$ \\
90PM050201 & 215.8 & +45.9 & $5.259 \mathrm{E}-03$ & 5.6 & 0 & 500 & $\mathrm{t}$ & 4 & $\mathrm{c}$ \\
90PM050301 & 249.8 & +33.1 & $9.626 \mathrm{E}-04$ & 3.8 & 300 & 540 & $\mathrm{t}$ & 4 & $\mathrm{o}$ \\
90PM050301 & 253.5 & +32.3 & $4.627 \mathrm{E}-04$ & 7.0 & 300 & 540 & $\mathrm{t}$ & 4 & $\mathrm{c}$ \\
90PM050401 & 248.2 & +35.7 & $7.827 \mathrm{E}-03$ & 1.6 & 300 & 500 & $\mathrm{t}$ & 3 & $\mathrm{o}$ \\
90PM050401 & 69.9 & -31.9 & $2.827 \mathrm{E}-03$ & 1.2 & 300 & 500 & $\mathrm{t}$ & 3 & $\mathrm{c}$ \\
90PM050501† & 269.8 & +1.7 & $2.461 \mathrm{E}-03$ & 3.4 & 300 & 560 & $\mathrm{t}$ & 5 & $\mathrm{o}$ \\
90PM050501† & 267.7 & -6.0 & $8.922 \mathrm{E}-04$ & 3.9 & 300 & 560 & $\mathrm{t}$ & 5 & $\mathrm{c}$ \\
90PM050601 & 264.6 & +40.0 & $7.883 \mathrm{E}-04$ & 2.2 & 400 & 575 & $\mathrm{t}$ & 6 & $\mathrm{o}$ \\
90PM050601 & 263.7 & +40.5 & $3.457 \mathrm{E}-04$ & 4.9 & 400 & 575 & $\mathrm{t}$ & 6 & $\mathrm{c}$ \\
90PM050701 & 245.0 & +55.3 & $1.695 \mathrm{E}-03$ & 2.0 & 450 & 560 & $\mathrm{t}$ & 4 & $\mathrm{o}$ \\
90PM050701 & 245.4 & +56.4 & $6.746 \mathrm{E}-04$ & 4.9 & 450 & 560 & $\mathrm{t}$ & 4 & $\mathrm{c}$ \\
90PM050801 & 260.4 & +63.8 & $7.662 \mathrm{E}-04$ & 5.0 & 300 & 300 & $\mathrm{t}$ & 1 & $\mathrm{o}$ \\
90PM050901 & 276.2 & +57.1 & $8.325 \mathrm{E}-04$ & 2.1 & 450 & 540 & $\mathrm{t}$ & 3 & $\mathrm{o}$ \\
90PM050901 & 274.7 & +63.5 & $1.834 \mathrm{E}-04$ & 7.0 & 450 & 540 & $\mathrm{t}$ & 3 & $\mathrm{c}$ \\
90PM051001 & 247.6 & +30.2 & $1.375 \mathrm{E}-03$ & 1.3 & 500 & 585 & $\mathrm{t}$ & 5 & $\mathrm{o}$ \\
90PM051001 & 67.2 & -30.9 & $8.186 \mathrm{E}-04$ & 2.0 & 500 & 585 & $\mathrm{t}$ & 5 & $\mathrm{c}$ \\
90PM051101 & 259.1 & +33.5 & $4.107 \mathrm{E}-03$ & 1.4 & 300 & 540 & $\mathrm{t}$ & 4 & $\mathrm{o}$ \\
90PM051101 & 258.4 & +33.5 & $1.620 \mathrm{E}-03$ & 3.4 & 300 & 540 & $\mathrm{t}$ & 4 & $\mathrm{c}$
\end{tabular}


Site PM06; N.Lat: 48.08, E.Lon: 236.08, DipAz: 270, Dip: 45

\begin{tabular}{crcccccccc} 
Sample & \multicolumn{1}{c}{ Dec } & \multicolumn{1}{c}{ Inc } & R & MAD & Low & High & $\begin{array}{c}\text { Demag. } \\
\text { Method }\end{array}$ & N & $\begin{array}{c}\text { Line-Fit } \\
\text { Type }\end{array}$ \\
\hline 90PM060102 & 130.2 & +79.2 & $2.584 \mathrm{E}-03$ & 0.7 & 300 & 540 & $\mathrm{t}$ & 4 & $\mathrm{o}$ \\
90PM060102 & 131.0 & +79.0 & $2.028 \mathrm{E}-03$ & 0.8 & 300 & 540 & $\mathrm{t}$ & 4 & $\mathrm{c}$ \\
90PM060201 & 121.8 & +73.5 & $6.146 \mathrm{E}-03$ & 1.9 & 300 & 500 & $\mathrm{t}$ & 3 & $\mathrm{o}$ \\
90PM060201 & 124.7 & +72.2 & $3.904 \mathrm{E}-03$ & 2.2 & 300 & 500 & $\mathrm{t}$ & 3 & $\mathrm{c}$ \\
90PM060301 & 25.4 & +67.0 & $6.270 \mathrm{E}-03$ & 1.2 & 150 & 400 & $\mathrm{t}$ & 6 & $\mathrm{o}$ \\
90PM060301 & 24.0 & +65.3 & $1.009 \mathrm{E}-03$ & 7.3 & 150 & 400 & $\mathrm{t}$ & 6 & $\mathrm{c}$ \\
90PM060402 & 97.9 & +80.6 & $2.400 \mathrm{E}-03$ & 0.7 & 300 & 500 & $\mathrm{t}$ & 3 & $\mathrm{o}$ \\
90PM060402 & 97.9 & +80.0 & $1.573 \mathrm{E}-03$ & 0.6 & 300 & 500 & $\mathrm{t}$ & 3 & $\mathrm{c}$ \\
90PM060501 & 110.2 & -58.7 & $4.262 \mathrm{E}-03$ & 1.0 & 300 & 500 & $\mathrm{t}$ & 3 & $\mathrm{o}$ \\
90PM060501 & 110.2 & -58.4 & $2.757 \mathrm{E}-03$ & 1.5 & 300 & 500 & $\mathrm{t}$ & 3 & $\mathrm{c}$ \\
90PM060601 & 118.4 & +77.5 & $5.909 \mathrm{E}-03$ & 1.1 & 300 & 540 & $\mathrm{t}$ & 4 & $\mathrm{o}$ \\
90PM060601 & 117.2 & +77.0 & $4.357 \mathrm{E}-03$ & 1.3 & 300 & 540 & $\mathrm{t}$ & 4 & $\mathrm{c}$ \\
90PM060701 & 33.4 & +66.8 & $5.421 \mathrm{E}-03$ & 4.7 & 0 & 450 & $\mathrm{t}$ & 3 & $\mathrm{o}$ \\
90PM060701 & 29.8 & +72.8 & $2.501 \mathrm{E}-03$ & 7.6 & 0 & 450 & $\mathrm{t}$ & 3 & $\mathrm{c}$
\end{tabular}

Site PM07; N.Lat: 48.09, E.Lon: 236.08, DipAz: 60, Dip: 91

\begin{tabular}{|c|c|c|c|c|c|c|c|c|c|}
\hline \multirow[b]{2}{*}{ Sample } & \multirow[b]{2}{*}{ Dec } & \multirow[b]{2}{*}{ Inc } & \multirow[b]{2}{*}{$\mathbf{R}$} & \multirow[b]{2}{*}{ MAD } & \multicolumn{2}{|c|}{ Demag. Range } & \multirow{2}{*}{$\begin{array}{l}\text { Demag. } \\
\text { Method }\end{array}$} & \multirow[b]{2}{*}{$\mathrm{N}$} & \multirow{2}{*}{$\begin{array}{c}\text { Line-Fit } \\
\text { Type }\end{array}$} \\
\hline & & & & & Low & High & & & \\
\hline 90PM070101 & 252.0 & +85.7 & $7.674 \mathrm{E}-04$ & 8.1 & 150 & 475 & $\mathrm{t}$ & 7 & 0 \\
\hline 90PM070101 & 21.9 & +85.0 & $2.937 \mathrm{E}-04$ & 18.6 & 150 & 475 & $t$ & 7 & c \\
\hline 90PM070201* & 257.5 & +35.6 & $2.450 \mathrm{E}-04$ & 7.0 & 300 & 540 & $\mathrm{t}$ & 4 & o \\
\hline 90PM070201* & 260.8 & +34.8 & $1.474 \mathrm{E}-04$ & 11.0 & 300 & 540 & $\mathrm{t}$ & 4 & c \\
\hline 90PM070301 & 201.1 & +55.5 & $4.622 \mathrm{E}-04$ & 5.4 & 450 & 540 & $\mathrm{t}$ & 3 & 0 \\
\hline 90PM070301 & 212.6 & +46.7 & $1.407 \mathrm{E}-04$ & 13.3 & 450 & 540 & $\mathrm{t}$ & 3 & c \\
\hline 90PM070401† & 127.8 & +19.0 & $5.138 \mathrm{E}-04$ & 5.9 & 300 & 540 & $\mathrm{t}$ & 4 & 0 \\
\hline 90PM070401† & 123.7 & +19.2 & $3.050 \mathrm{E}-04$ & 8.6 & 300 & 540 & $\mathrm{t}$ & 4 & c \\
\hline 90PM070501 & 263.0 & +78.3 & $2.737 \mathrm{E}-04$ & 6.9 & 300 & 540 & $\mathrm{t}$ & 4 & o \\
\hline 90PM070501 & 244.3 & +76.8 & $8.688 \mathrm{E}-05$ & 20.6 & 300 & 540 & $\mathrm{t}$ & 4 & c \\
\hline 90PM070601 & 231.7 & +67.5 & $4.292 \mathrm{E}-04$ & 3.6 & 300 & 560 & $\mathrm{t}$ & 5 & o \\
\hline 90PM070601 & 231.9 & +69.7 & $1.889 \mathrm{E}-04$ & 7.8 & 300 & 560 & $\mathrm{t}$ & 5 & c \\
\hline 90PM070701† & 145.2 & +57.6 & $8.839 E-04$ & 1.2 & 450 & 540 & $t$ & 3 & 0 \\
\hline 90PM070701 $\dagger$ & 147.9 & +57.5 & $2.902 \mathrm{E}-04$ & 3.2 & 450 & 540 & $\mathrm{t}$ & 3 & c \\
\hline 90PM070801 & 255.9 & +77.5 & $2.150 \mathrm{E}-04$ & 5.5 & 300 & 540 & $t$ & 4 & o \\
\hline 90PM070801 & 208.1 & +86.4 & $7.463 \mathrm{E}-05$ & 11.5 & 300 & 540 & $t$ & 4 & c \\
\hline 90PM070901 & 241.4 & +74.9 & $1.256 \mathrm{E}-04$ & 3.1 & 450 & 540 & $t$ & 3 & 0 \\
\hline 90PM070901 & 213.7 & +77.2 & $3.415 \mathrm{E}-05$ & 8.5 & 450 & 540 & $\mathrm{t}$ & 3 & c \\
\hline
\end{tabular}


Site SP01; N.Lat: 48.08, E.Lon: 235.87, DipAz: 337, Dip: 45

\begin{tabular}{|c|c|c|c|c|c|c|c|c|c|}
\hline \multirow[b]{2}{*}{ Sample } & \multirow[b]{2}{*}{ Dec } & \multirow[b]{2}{*}{ Inc } & \multirow[b]{2}{*}{$\mathbf{R}$} & \multirow[b]{2}{*}{ MAD } & \multicolumn{2}{|c|}{ Demag. Range } & \multirow{2}{*}{$\begin{array}{l}\text { Demag. } \\
\text { Method }\end{array}$} & \multirow[b]{2}{*}{$\mathrm{N}$} & \multirow{2}{*}{$\begin{array}{c}\text { Line-Fit } \\
\text { Type }\end{array}$} \\
\hline & & & & & Low & High & & & \\
\hline 90SP010101 & 346.9 & +50.7 & $6.696 \mathrm{E}-04$ & 3.8 & 300 & 560 & $t$ & 5 & 0 \\
\hline 90SP010101 & 344.7 & +55.1 & 3.897E-04 & 3.3 & 300 & 560 & $\mathrm{t}$ & 5 & c \\
\hline 90SP010201 & 333.2 & -18.8 & $7.378 \mathrm{E}-04$ & 12.4 & 300 & 540 & $\mathrm{t}$ & 4 & 0 \\
\hline 90SP010201 & 333.7 & -4.8 & $4.561 \mathrm{E}-04$ & 11.3 & 300 & 540 & $t$ & 4 & c \\
\hline 90SP010301 & 152.9 & +22.8 & $1.116 \mathrm{E}-03$ & 1.4 & 450 & 560 & $\mathrm{t}$ & 4 & 0 \\
\hline 90SP010301 & 155.0 & +22.8 & $3.388 \mathrm{E}-04$ & 4.3 & 450 & 560 & $\mathrm{t}$ & 4 & c \\
\hline 90SP010401 & 146.5 & +37.5 & $3.277 \mathrm{E}-04$ & 8.7 & 450 & 540 & $\mathrm{t}$ & 3 & 0 \\
\hline 90SP010401 & 123.0 & +19.4 & $1.049 \mathrm{E}-04$ & 1.6 & 450 & 540 & $\mathrm{t}$ & 3 & c \\
\hline 90SP010501 & 251.0 & -21.1 & $1.444 \mathrm{E}-03$ & 2.1 & 450 & 540 & $t$ & 3 & 0 \\
\hline 90SP010501 & 254.7 & -8.6 & $2.142 \mathrm{E}-04$ & 5.6 & 450 & 540 & $t$ & 3 & c \\
\hline 90SP010601 & 308.3 & +64.3 & $1.718 \mathrm{E}-03$ & 3.9 & 150 & 540 & $\mathrm{t}$ & 9 & 0 \\
\hline 90SP010601 & 325.9 & +68.0 & $6.505 \mathrm{E}-04$ & 5.7 & 150 & 540 & $\mathrm{t}$ & 9 & c \\
\hline
\end{tabular}

Site SP02; N.Lat: 48.08, E.Lon: 235.87, DipAz: 337, Dip: 45

\begin{tabular}{|c|c|c|c|c|c|c|c|c|c|}
\hline \multirow[b]{2}{*}{ Sample } & \multirow[b]{2}{*}{ Dec } & \multirow[b]{2}{*}{ Inc } & \multirow[b]{2}{*}{$\mathbf{R}$} & \multirow[b]{2}{*}{ MAD } & \multicolumn{2}{|c|}{ Demag. Range } & \multirow{2}{*}{$\begin{array}{l}\text { Demag. } \\
\text { Method }\end{array}$} & \multirow[b]{2}{*}{$\mathrm{N}$} & \multirow{2}{*}{ Line-Fit } \\
\hline & & & & & Low & High & & & \\
\hline 90SP020101 & 251.4 & +10.2 & $9.430 \mathrm{E}-04$ & 2.4 & 450 & 540 & $t$ & 3 & 0 \\
\hline 90SP020101 & 254.6 & +12.7 & $2.810 \mathrm{E}-04$ & 7.0 & 450 & 540 & $\mathrm{t}$ & 3 & c \\
\hline 90SP020201 & 37.7 & +60.8 & $2.923 \mathrm{E}-03$ & 2.2 & 0 & 500 & $\mathrm{t}$ & 4 & 0 \\
\hline 90SP020201 & 36.5 & +58.9 & $2.169 \mathrm{E}-03$ & 0.4 & 0 & 500 & $\mathrm{t}$ & 4 & c \\
\hline 90SP020301 & 277.1 & +66.9 & $1.897 \mathrm{E}-03$ & 5.4 & 300 & 540 & $t$ & 4 & 0 \\
\hline 90SP020301 & 310.9 & +71.0 & $6.602 \mathrm{E}-04$ & 8.5 & 300 & 540 & $t$ & 4 & c \\
\hline 90SP020402 & 341.7 & +72.2 & $7.660 \mathrm{E}-05$ & 4.4 & 450 & 540 & $\mathrm{t}$ & 3 & 0 \\
\hline 90SP020402 & 332.1 & +80.2 & $3.556 \mathrm{E}-05$ & 2.5 & 450 & 540 & $\mathrm{t}$ & 3 & c \\
\hline 90SP020501 & 304.3 & +53.4 & $5.065 \mathrm{E}-04$ & 4.1 & 450 & 540 & $\mathrm{t}$ & 3 & 0 \\
\hline 90SP020501 & 331.1 & +57.6 & $1.298 \mathrm{E}-04$ & 2.8 & 450 & 540 & $t$ & 3 & c \\
\hline 90SP020601* & 175.9 & +83.2 & $7.036 \mathrm{E}-04$ & 9.7 & 300 & 500 & $\mathrm{t}$ & 3 & 0 \\
\hline 90SP020601* & 18.6 & +82.4 & $3.949 \mathrm{E}-04$ & 5.3 & 300 & 500 & $t$ & 3 & c \\
\hline
\end{tabular}

